Illinois State University

ISU ReD: Research and eData

Theses and Dissertations

10-16-2017

\title{
Diurnal And Seasonal Variation In Groundwater Nitrate-N Concentration In A Saturated Buffer Zone
}

Joseph Miller

Illinois State University, jjmill2@ilstu.edu

Follow this and additional works at: https://ir.library.illinoisstate.edu/etd

Part of the Geochemistry Commons, Geology Commons, and the Hydrology Commons

\section{Recommended Citation}

Miller, Joseph, "Diurnal And Seasonal Variation In Groundwater Nitrate-N Concentration In A Saturated Buffer Zone" (2017). Theses and Dissertations. 821.

https://ir.library.illinoisstate.edu/etd/821

This Thesis is brought to you for free and open access by ISU ReD: Research and eData. It has been accepted for inclusion in Theses and Dissertations by an authorized administrator of ISU ReD: Research and eData. For more information, please contact ISUReD@ilstu.edu. 


\title{
DIURNAL AND SEASONAL VARIATION IN GROUNDWATER NITRATE-N CONCENTRATION IN A SATURATED BUFFER ZONE
}

\author{
Joseph Miller
}

\section{Pages}

Surface water pollution by nitrate $\left(\mathrm{NO}_{3}^{-}\right)$is identified as a critical problem in agricultural land-use areas. Excess $\mathrm{NO}_{3}{ }^{-}$loading causes eutrophication and hypoxia in near-shore marine waters such as the Gulf of Mexico. Diversion of agricultural runoff into saturated buffer zones reduces $\mathrm{NO}_{3}{ }^{-}$loading. Although the mechanisms responsible for $\mathrm{NO}_{3}{ }^{-}$reduction in saturated buffer zones are well characterized, little is known about how $\mathrm{NO}_{3}{ }^{-}$concentrations vary temporally and what factors control those changes. The objective of this study is to understand $\mathrm{NO}_{3}{ }^{-}$concentration and environmental factor variability in a saturated buffer zone on a diurnal scale within and among the different seasons. Weekly 24-hour sampling events occurred between September 2016 and August 2017 with groundwater collected hourly from a saturated buffer zone located in central Illinois. Water samples were withdrawn from a well screened in an unconfined aquifer at $1.5 \mathrm{~m}$ below the surface. Seasons were defined by the 2017 solstices and equinoxes: Spring: March, 20 - June, 20; Summer: June, 21 - September, 21; Fall: September, 22 - December, 20; Winter: December, 21 - March, 19. Each collection event drew samples every hour for 24-hours; each sample was analyzed for nitrate as nitrogen $\left(\mathrm{NO}_{3}{ }^{-}-\mathrm{N}\right)$. Mean daily $\mathrm{NO}_{3}{ }^{-}-\mathrm{N}$ concentration ranged from $2.18 \mathrm{mg} / \mathrm{L}$ in the fall to $4.63 \mathrm{mg} / \mathrm{L}$ in the summer and varied by a statistically significant difference for spring-fall $(t(15.90)=2.70, p=0.02)$ and summer-fall $(t(10.91)=4.83, p=0.00)$ combinations. The differences between maximum and minimum $\mathrm{NO}_{3}^{-}-\mathrm{N}$ concentration measured over the 24 hour periods were statistically significant within spring 
$(t(12)=2.76, p=0.01)$, summer $(t(8)=6.83, p=0.00)$, fall $(t(4)=4.34, p=0.01)$, and winter $(t(5)=3.33, p=0.01)$. Vegetation uptake was identified as a process controlling 24-hour $\mathrm{NO}_{3}{ }^{-}-\mathrm{N}$ concentration variability by the presence of a sinusoidal trend and daily timing of maximum (dark period) and minimum $\mathrm{NO}_{3}{ }^{-}-\mathrm{N}$ (photoperiod) concentrations that coincide with photoperiod. $\mathrm{NO}_{3}{ }^{-}$leaching, ET, and nitrification were identified as processes controlling $\mathrm{NO}_{3}{ }^{-}-\mathrm{N}$ concentration increases by the presence of an increase trend and $\mathrm{NO}_{3}{ }^{-}-\mathrm{N}: \mathrm{Cl}^{-}$rates of increase over 24-hours. There were no statistically significant differences between the magnitude of mean difference between daily maximum and minimum $\mathrm{NO}_{3}{ }^{-}-\mathrm{N}$ concentration among seasons, indicating the amount of $\mathrm{NO}_{3}{ }^{-}$available does not influence the magnitude of change over 24hours. The magnitude of difference between daily maximum and minimum $\mathrm{NO}_{3}{ }^{-}-\mathrm{N}$ concentration had: no correlation with daily average air temperature, no correlation with solar intensity, and no correlation with mean daily water temperature. This study has demonstrated that variation in $\mathrm{NO}_{3}{ }^{-}$concentration exists on both the seasonal and diurnal scale, multiple processes operate to produce variation, and that variation over 24-hours is consistent across processes.

KEYWORDS: Denitrification, Nitrate, Saturated Buffer, Groundwater, Water Quality, Vegetation Uptake 


\title{
DIURNAL AND SEASONAL VARIATION IN GROUNDWATER NITRATE-N CONCENTRATION IN A SATURATED BUFFER ZONE
}

\author{
JOSEPH MILLER
}

\author{
A Thesis Submitted in Partial \\ Fulfillment of the Requirements \\ for the Degree of \\ MASTER OF SCIENCE \\ Department of Geography, Geology, and The Environment \\ ILLINOIS STATE UNIVERSITY
}


Copyright 2017 Joseph Miller 


\section{DIURNAL AND SEASONAL VARIATION IN GROUNDWATER NITRATE-N CONCENTRATION IN A SATURATED BUFFER ZONE}

JOSEPH MILLER

COMMITTEE MEMBERS:

Eric Peterson, Chair

Dagmar Budikova

Wondwosen Seyoum 


\section{ACKNOWLEDGMENTS}

I would like to acknowledge those who supported this project. I thank my committee for teaching me how to do research and improve my writing. I thank Eric Peterson for his unwavering dedication to help in every aspect of the project. I thank Catherine O'Reilly and Victoria Heath for helping me analyze samples. This project wouldn't have been possible without the financial support from the following: Geologic Society of America, Illinois Water Resource Center, City of Bloomington, Illinois Groundwater Association, Illinois State University Graduate School, and Illinois State University Department of Geography, Geology, and The Environment.

J.M. 


\section{CONTENTS}

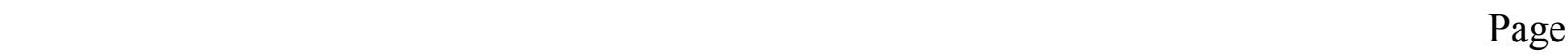

ACKNOWLEDGMENTS

CONTENTS

TABLES

FIGURES $\quad$ iv

CHAPTER I: INTRODUCTION 1

$\begin{array}{lr}\text { Questions and Hypotheses } & 8\end{array}$

$\begin{array}{ll}\text { Site Description } & 9\end{array}$

$\begin{array}{ll}\text { CHAPTER II: METHODS } & 13\end{array}$

CHAPTER III: RESULTS 15

$\begin{array}{ll}\text { Nitrate-N data } & 15\end{array}$

$\begin{array}{ll}\text { Statistical Analyses of Nitrate-N Data } & 18\end{array}$

$\begin{array}{ll}\text { Environmental Factors } & 32\end{array}$

CHAPTER IV: DISCUSSION

CHAPTER V: CONCLUSION

$\begin{array}{ll}\text { REFERENCES } & 45\end{array}$

APPENDIX A: COLLECTED DATA BY DAY 52

APPENDIX B: COLLECTED DATA BY HOUR 56 


\section{TABLES}

Table

Page

1. $\mathrm{NO}_{3}{ }^{-}-\mathrm{N}$ Concentration Mean \pm Standard Deviation by Season.

2. t-test Results for Statistically Significant Difference Between

$\mu_{\max \left[\mathrm{NO}^{-}-\mathrm{N}\right]}$ and $\mu_{\min \left[\mathrm{NO}^{-}-\mathrm{N}\right]}$.

3. t-test Results for Statistically Significant Difference Between

$\mu_{\text {difference }\left[\mathrm{NO}^{-}-\mathrm{N}\right] \text { season }}$ and $\mu_{\text {difference }\left[\mathrm{NO}^{-}{ }^{-} \mathrm{N}\right] \text { season. }}$

4. t-test Results for Statistically Significant Difference Between

$$
\mu_{\text {daily }\left[\mathrm{NO}^{-}-\mathrm{N}\right] \text { season }} \text { and } \mu_{\text {daily }\left[\mathrm{NO}^{-}-\mathrm{N}\right] \text { season. }}
$$

5. Seasonal Means \pm Standard Deviation for Environmental Factors. 


\section{FIGURES}

Figure $\quad$ Page

$\begin{array}{ll}\text { 1. Nitrogen Cycle. } & 3\end{array}$

2. Diurnal variation in $\mathrm{NO}_{3}{ }^{-}$uptake rate in Soybean (Delhon et al., 1996). 5

3. Visual of field site A) general site location in Illinois, B) local site location. $\quad 10$

4. Conceptual model of subsurface flow. 11

5. $\mathrm{NO}_{3}{ }^{-}-\mathrm{N}$ concentrations and environmental factors observed during the 24-hour collection periods.

6. Time series trends for normalized $\left[\mathrm{NO}_{3}^{-}-\mathrm{N}\right]$ (circle) and $\left[\mathrm{Cl}^{-}\right]$(triangle) over the course of the study.

7. Bar graph displaying frequency of maximum $\mathrm{NO}_{3}^{-}-\mathrm{N}$ concentration by time-of-day for increase, decrease, and sinusoidal trends.

8. Bar graph displaying frequency of minimum $\mathrm{NO}_{3}{ }^{-}-\mathrm{N}$ concentration by time-of-day for increase, decrease, and sinusoidal trends.

9. Bar graph displaying frequency of maximum $\mathrm{NO}_{3}{ }^{-}-\mathrm{N}$ concentration by time-of-day for sinusoidal trends.

10. Bar graph displaying frequency of minimum $\mathrm{NO}_{3}^{-}-\mathrm{N}$ concentration by time-of-day for sinusoidal trends.

11. Daily $\mathrm{NO}_{3}{ }^{-}-\mathrm{N}$ concentration by season.

12. Daily maximum and minimum $\mathrm{NO}_{3}{ }^{-}-\mathrm{N}$ concentrations for each season.

13. Box and whisker plots for the differences between daily maximum and minimum $\mathrm{NO}_{3}{ }^{-}-\mathrm{N}$ concentration for each season. 
14. Frequency of $\mathrm{NO}_{3}{ }^{-}-\mathrm{N}$ concentration increase, decrease, and sinusoidal trends by season.

15. Environmental factor correlations for sinusoidal, increase, and decrease trends by season.

16. $\mu_{\text {daily }}\left[\mathrm{NO}_{3}{ }^{-}-\mathrm{N}\right]$ concentrations versus $\mu_{\text {differnece }}\left[\mathrm{NO}_{3}{ }^{-} \mathrm{N}\right]$ for sinusoidal pattern. 


\section{CHAPTER I: INTRODUCTION}

Nitrate $\left(\mathrm{NO}_{3}{ }^{-}\right)$pollution from agricultural runoff is recognized as a significant issue that deteriorates stream water quality in agricultural regions (Hutchins, 2012). Often, fertilizers containing $\mathrm{NO}_{3}{ }^{-}$are not completely absorbed by crops, and much of the $\mathrm{NO}_{3}{ }^{-}$is dissolved and transported by runoff following precipitation events (North et al., 2013). David et al. (1997)

found precipitation to be a strong controlling factor of $\mathrm{NO}_{3}{ }^{-}$export from agricultural fields. The authors noted that intense rainfall can cause large amounts of export in short time windows (David et al., 1997). Even under optimal growing conditions, crop grain yield only contains about $50 \%$ of the nitrogen added, while the rest of the nitrogen remains within or is exported from the system (Oberle \& Keeney, 1990). In much of Illinois and many areas of the Midwest, agricultural fields are drained with subsurface drain tile to ensure economically favorable and practical crop production (Fausey et al., 1995). In regions dominated by drain tile use, the majority of $\mathrm{NO}_{3}{ }^{-}$rich runoff is transported by drain tile.

Runoff containing $\mathrm{NO}_{3}{ }^{-}$is problematic, because nitrogen as $\mathrm{NO}_{3}{ }^{-}$is a limiting nutrient in near-shore marine ecosystems causing eutrophication, the enrichment of an aquatic ecosystem with excess nutrients (Ryther \& Dunstan, 1971). This enrichment stimulates the overgrowth of photosynthetic organisms, such as algae, by releasing them from nutrient limitation. As photosynthetic organisms consume excess nutrients, nutrient levels return to pre-eutrophication concentrations. The overgrown photosynthetic population can no longer be sustained by the preeutrophication nutrient levels and decomposition ensues. Decomposition of organic matter consumes oxygen, and the decomposition of the overgrown photosynthetic population quickly consumes all of the dissolved oxygen in the area (Ryther \& Dunstan, 1971). Oxygen depletion affects the entire food web, and often results in the collapse of the ecosystem and a loss of food 
resources (Rabalais et al., 2002). The Illinois River is recognized as the second largest contributor of $\mathrm{NO}_{3}{ }^{-}$to the Mississippi River (Scott et al., 2007), contributing $19 \%$ of total $\mathrm{NO}_{3}{ }^{-}$ conveyed to the Gulf of Mexico (David \& Gentry, 2000, Keeney \& Hatfield, 2001). Therefore, the current and future health of nearshore marine ecosystems depends on the abatement of $\mathrm{NO}_{3}{ }^{-}$ pollution from agricultural regions including Illinois.

One way by which $\mathrm{NO}_{3}{ }^{-}$contamination can be controlled is saturated buffer zones. $\mathrm{NO}_{3}{ }^{-}$ removal in saturated buffer zones occurs through denitrification and assimilation. Denitrification is the process where $\mathrm{NO}_{3}{ }^{-}$is converted to dinitrogen $\left(\mathrm{N}_{2}\right)$ through microbial metabolism under anaerobic conditions (Zumft, 1997) (Figure 1). Dissolved organic carbon (DOC), an aqueous organic carbon source, is utilized by microbes as an energy source. Increasing DOC has been shown to increase denitrification when denitrifying microbes are DOC-limited (Hill et al., 2000). Denitrification results in the permanent removal of $\mathrm{NO}_{3}{ }^{-}$due to the loss on nitrogen as dinitrogen to the atmosphere. Assimilation occurs by incorporation of nitrogen into biomass through vegetation uptake (Kuusemets et al., 2001) (Figure 1). Over time, plant biomass containing assimilated nitrogen decomposes and releases organic nitrogen back into the environment (Mengel, 1996). Organic nitrogen can then be converted to ammonium $\left(\mathrm{NH}_{4}^{+}\right)$by microbial ammonification, which can occur under aerobic or anaerobic conditions (Hefting et al., 2004). Ammonium can then be converted back to $\mathrm{NO}_{3}{ }^{-}$by microbial nitrification, which can occur under aerobic conditions (Hefting et al., 2004) (Figure 1). These processes are collectively called mineralization, representing the conversion of organic nitrogen to inorganic nitrogen (Hefting et al., 2004). Although the mechanisms responsible for nitrate reduction in riparian buffer zones are well characterized, little is known about how $\mathrm{NO}_{3}{ }^{-}$concentrations vary temporally and the factors involved in these changes. 


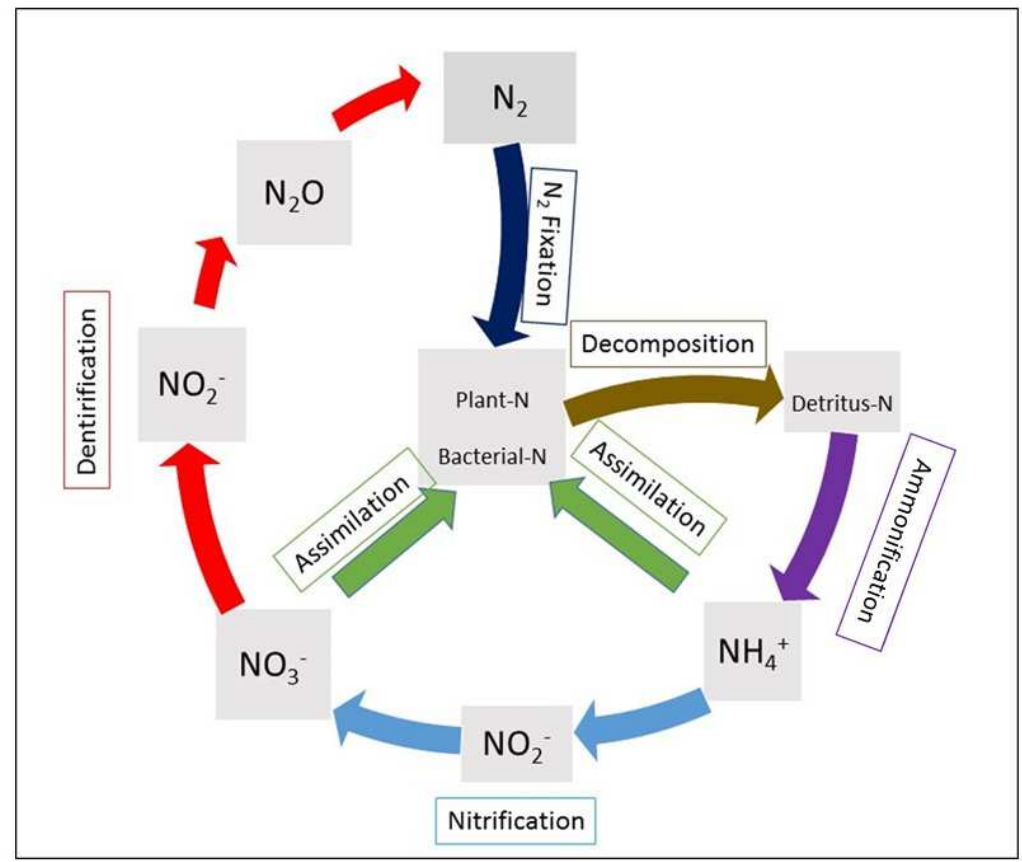

Figure 1. Nitrogen Cycle.

Temporal variation in $\mathrm{NO}_{3}{ }^{-}$removal is plausible on the seasonal and diurnal scale due to temporal changes in solar radiation. Diurnal and seasonal changes in solar radiation influence air temperature, groundwater temperature, and photosynthetic activity. Vegetation uptake and bacterial denitrification may be influenced by these temporal changes in different ways.

Vegetation uptake of $\mathrm{NO}_{3}{ }^{-}$is controlled by photosynthesis, the mechanism by which plants capture photons to produce energy. Photosynthesis uses carbon dioxide $\left(\mathrm{CO}_{2}\right)$ and water to manufacture sugars in leaves, which releases oxygen as a byproduct. Oxygen is released to the atmosphere or transported to root tissue where it is consumed with photosynthetically manufactured sugars during respiration (Bedford et al., 1991). Bedford et al. (1991) found that little oxygen transported to root tissue of wetland plants is released, as it is consumed by the root tissue or aerobic bacteria on root surfaces. Photosynthetically produced energy, in the form of 
sugars, is used to uptake nitrogen as $\mathrm{NO}_{3}{ }^{-}$and manufacture proteins, nucleic acids, coenzymes, and numerous plant secondary products (Miller \& Cramer, 2005). Photosynthesis is sensitive to light availability and air temperature, therefore leaving nitrogen uptake and biomass growth subject to cyclic patterns. Delhon et al. (1996) found soybean $\mathrm{NO}_{3}{ }^{-}$uptake rate to be 1.5 to 2 times higher when light is available compared to when light is absent (Figure 2).

The dominant species on the study site, Switchgrass, is known to have a well-developed root system and a great capacity for $\mathrm{NO}_{3}{ }^{-}$uptake (Schimel, 1986), capable of recovering 66\% of applied nitrogen (Bransby et al., 1998). This study site is not fertilized and Switchgrass is not known to be a substantial nitrifier, but several recent studies have found nitrogen fertilization to greatly increase biomass yield (Lemus et al., 2008, Guretzky et al., 2011). 


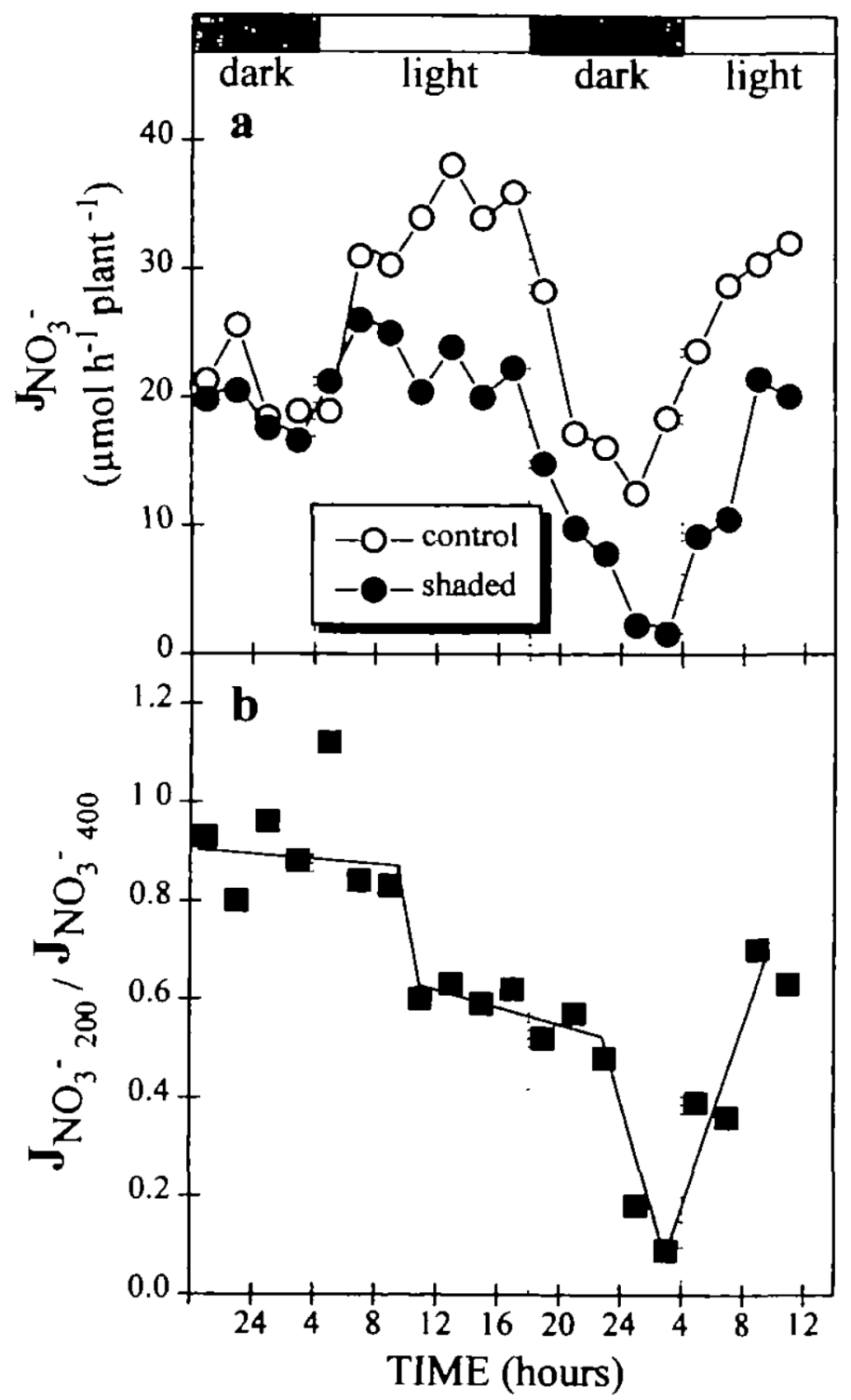

Figure 2. Diurnal variation in $\mathrm{NO}_{3}{ }^{-}$uptake rate in Soybean (Delhon et al., 1996).

Several studies performed under laboratory conditions offer evidence for $\mathrm{NO}_{3}{ }^{-}$uptake variation on the diurnal scale, which may be expanded to explain variation on a seasonal scale. Studies report $\mathrm{NO}_{3}{ }^{-}$uptake peak during the photoperiod (Delhon et al., 1996, Scaife \& Schloemer, 1994, Bot \& Kirkby, 1992, Pearson \& Steer, 1977). Delhon et al. (1996) and Pearson and Steer (1977) reasoned that diurnal changes in $\mathrm{NO}_{3}{ }^{-}$uptake are due to decreased phloem 
transport of photosynthates in darkness. Phloem is a vascular tissue that transports photosynthetically manufactured sugars and metabolic products down to root tissue (Delhon et al., 1996). The lack of activity in darkness leaves root tissue lacking energy for uptake (Delhon et al., 1996). If $\mathrm{NO}_{3}{ }^{-}$uptake is influenced by light availably on the diurnal scale, then $\mathrm{NO}_{3}{ }^{-}$ uptake variation can be expected to display a similar relationship on the seasonal scale as solar intensity varies.

Seasonal changes in air and groundwater temperature may impact denitrification. Monitoring soils in Chesapeake Bay, Maryland, Weller et al. (1994), found $\mathrm{N}_{2} \mathrm{O}$ emissions from denitrification to vary with temperature from December-May and September-November. These results agree with experiments performed under laboratory conditions that demonstrate biologic denitrification to increase with temperature by a reaction rate coefficient of 2 within $15-35^{\circ} \mathrm{C}$ and decrease abruptly at $5-10^{\circ} \mathrm{C}$ (Stanford et al., 1975). However, not all studies agree on the relationship that exists between denitrification and temperature. Pinay et al. (1993) and Groffman et al. (1992) observed peak denitrification during winter months in soils. Any attenuation of $\mathrm{NO}_{3}{ }^{-}$discharges during the winter months is assumed to be denitrification due to vegetation dormancy (Jacks et al., 1994, Haycock \& Pinay, 1993). Diurnal variation in denitrification within and between seasons likely depends on groundwater temperature reaching the 5 to $10^{\circ}$ Celsius threshold identified by Stanford et al. (1975).

The relative importance of plant uptake compared to the role of microbial denitrification is disputed. Gilliam (1994) found $\mathrm{NO}_{3}{ }^{-}$loss to be greatest in the winter months when plants are dormant, and Sabater et al. (2003) found no seasonal difference in $\mathrm{NO}_{3}{ }^{-}$removal in riparian buffers over a variety of climate and plant types. However, other research suggests $\mathrm{NO}_{3}{ }^{-}$uptake by vegetation is important and the resulting seasonal variation is significant (Hill, 1996). In a 
field study, Haycock and Pinay (1993) found riparian vegetation uptake to be a major $\mathrm{NO}_{3}{ }^{-}$ attenuation mechanism in summer. Haycock and Pinay (1993) and Simmons et al. (1992) reasoned that vegetation uptake dominates when the water table is high enough for roots to reach it but low enough for overlying soil to become aerated. An intermediate water table location provides ideal conditions needed for plant uptake. In landscapes where riparian zones are underlain by a low hydraulic conductivity material, restricted downward flow leaves the majority of flow in the horizontal plane through the aquifer sediment (Hill, 1996). This hydrogeologic setting, similar to this study site, restricts groundwater movement to a local flow system in the surficial unconfined aquifer and results in seasonal water table fluctuations governed by upland recharge (Lowrance, 1992, Pinay et al., 1993, Jordan et al., 1993, Hill, 1996) and evapotranspiration (Satchithanantham et al., 2017). Studies agree that denitrification and vegetation uptake operate simultaneously or independently depending on environmental conditions that may change within or between seasons (Sabater et al., 2003, Haycock \& Pinay, 1993, Simmons et al., 1992).

Environmental factors such as solar intensity, air temperature, groundwater temperature, water table location, and dissolved oxygen may influence $\mathrm{NO}_{3}{ }^{-}$concentration and account for the discrepancies among reported studies (Sabater et al., 2003, Gilliam, 1994, Hill, 1996). Groundwater $\mathrm{NO}_{3}{ }^{-}$concentration may correlate with diurnal and seasonal solar intensity patterns only when the water table is low but not beyond the reach of roots during a growing season. A growing season is characterized by warm groundwater, warm air temperatures, and increased solar intensity. Dissolved oxygen (DO) concentration in groundwater is known to influence denitrification. Gómez et al. (2002) demonstrated that the presence of DO decreased the removal 
efficiency of denitrifying bacteria in a controlled denitrifying bioreactor. The authors concluded that regardless of the carbon source used, denitrification sharply decreased above $4.5 \mathrm{mg} / \mathrm{L} \mathrm{DO}$.

\section{Questions and Hypotheses}

This work examines the variability of $\mathrm{NO}_{3}{ }^{-}$concentrations in a saturated buffer zone on a diurnal scale within and among seasons. Specifically, the research addresses the following questions and hypotheses. "Does riparian zone shallow groundwater $\mathrm{NO}_{3}$ " concentration vary temporally?" This question can be broken into the following questions and hypotheses: 1) Does $\mathrm{NO}_{3}{ }^{-}-\mathrm{N}$ concentration vary over a 24 -hour period in each season? $\mathrm{H}_{0}$ : There will be no significant difference between the mean daily maximum $\left(\mu_{\max \left[\mathrm{NO}^{-}-\mathrm{N}\right]}\right)$ and minimum $\left(\mu_{\min \left[\mathrm{NO}^{-}\right.}{ }^{-}\right.$

N]) $\mathrm{NO}_{3}{ }^{-}-\mathrm{N}$ concentration in each season; 2) Does mean daily $\mathrm{NO}_{3}^{-}-\mathrm{N}$ concentration vary seasonally? $\mathrm{H}_{0}$ : There will be no significant difference in mean daily $\mathrm{NO}_{3}{ }^{-}-\mathrm{N}$ concentration $\left(\mu_{\text {daily }}\right.$ $\left[\mathrm{NO}^{-}-\mathrm{N}\right]$ ) seasonally; 3) Does the daily timing of maximum and minimum $\mathrm{NO}_{3}{ }^{-}-\mathrm{N}$ concentration vary seasonally? $\mathrm{H}_{0}$ : There will be no difference in the time-of-day when the maximum and minimum $\mathrm{NO}_{3}^{-}-\mathrm{N}$ concentration occurs among seasons; 4) Does the mean difference between daily maximum and minimum $\mathrm{NO}_{3}{ }^{-}-\mathrm{N}$ concentration vary seasonally? $\mathrm{H}_{0}$ : There will be no significant difference between the mean daily maximum and minimum $\mathrm{NO}_{3}^{-}-\mathrm{N}$ concentration difference $\left(\mu_{\text {difference }\left[\mathrm{NO}^{-}-\mathrm{N}\right]}\right)$ among seasons. In addition to addressing the above hypotheses, environmental factors were used to investigate processes responsible for statistically significant differences. 


\section{Site Description}

Site T3 is a herbaceous saturated buffer area located $3 \mathrm{~km} \mathrm{NW}$ of Hudson, IL $\left(40.614382^{\circ} \mathrm{N},-89.023542^{\circ} \mathrm{W}\right)$ that receives agricultural runoff from a farm located approximately 120 m east (Figure 3). Historically, the site was farmed but has since been fully converted to a switchgrass prairie. The T3 saturated buffer area has been outfitted with an agricultural runoff treatment system that diverts a portion of agricultural runoff into the subsurface of the saturated buffer area. The agricultural runoff is directed into 3 perforated pipes $\sim 1 \mathrm{~m}$ below the surface by a diversion system, while the remaining volume is discharged directly into the stream (Figure 3). The perforated diversion pipes direct flow into the herbaceous saturated zone 20-35 m upgradient from the stream. This saturated zone allows tile discharge to infiltrate into the unconfined aquifer. Nests of wells have been installed to monitor water chemistry, with the well of interest (Figure 3) for this study screened at a depth of $1.5 \mathrm{~m}$, with an average depth to water (DTW) of $1.56 \mathrm{~m}$ and a range of $1.12-1.78 \mathrm{~m}$ over a year. Overall, the saturated buffer area gently slopes to the W-NW away from the agricultural area. 


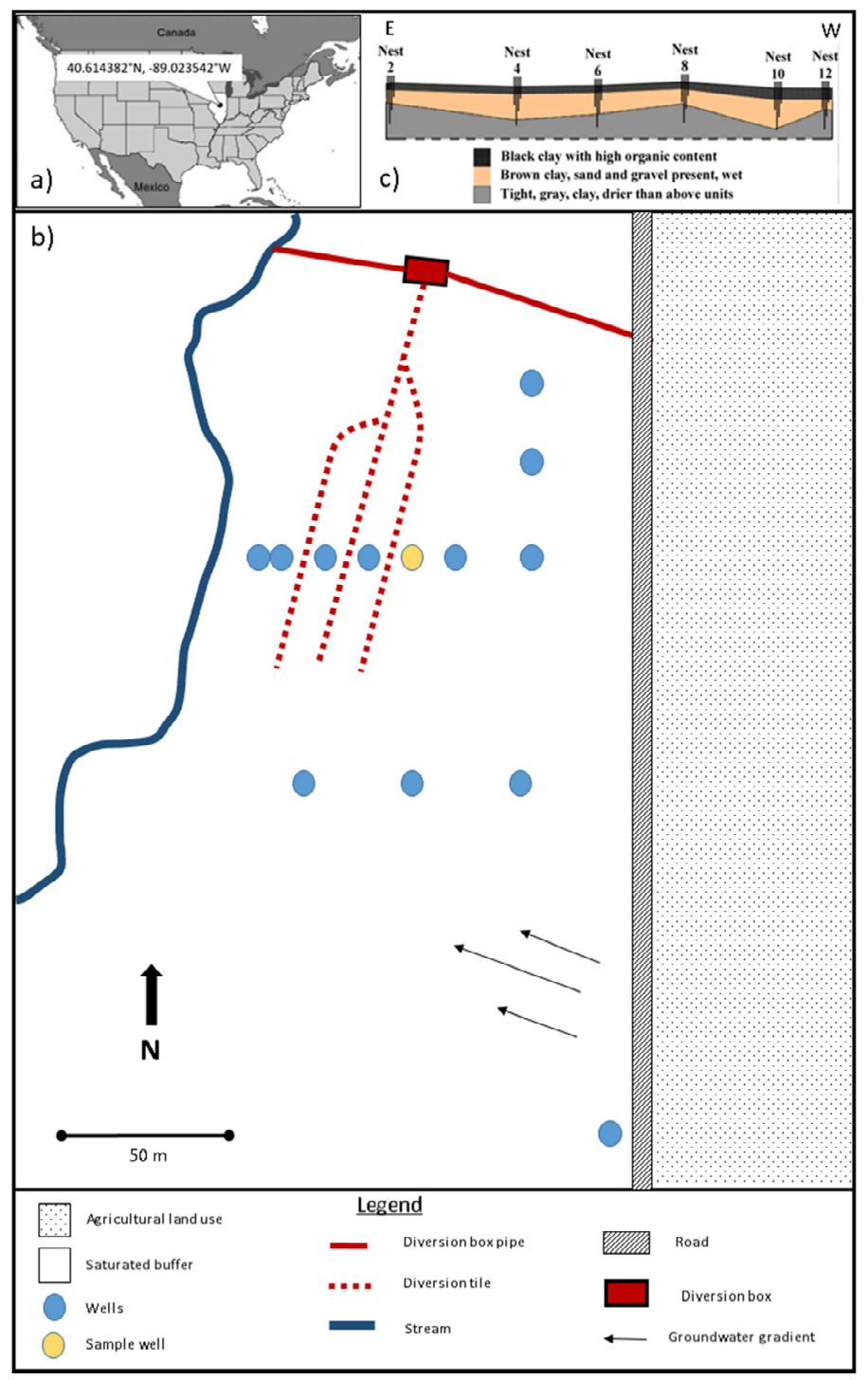

Figure 3. Visual of field site A) general site location in Illinois, B) local site location. Well of interest is yellow. The stream flows north and groundwater flows from the southeast to northwest, c) east to west cross-section illustrating the surficial geology.

At the surface $(0-0.63 \mathrm{~m})$ is dark organic rich topsoil that is underlain $(0.66-1.5 \mathrm{~m})$ by a firm clay loam composed of silty clay, clay, and sandy clay (Figure 4). The clay loam is graded with an increasing sand and gravel percent composition with depth. The clay loam transitions to coarse grained material composed of gravely silt with sand, sandy silt, and clayey sand from 1.5 
$\mathrm{m}$ to $2 \mathrm{~m}$ depth, but the thickness of this coarse grained zone varies with location. Coarse grained material is underlain ( $>2 \mathrm{~m}$ ) of fat clay (Figure 4$)$. The fat clay is a blue-grey, poorly sorted 3.9$62.5 \mu \mathrm{m}$ mud matrix diamicton that oxidizes yellow-brown (Weedman et al., 2014). The fat clay is thought to have an average thickness of 30-45 $\mathrm{m}$ terminating at Silurian dolomite bedrock (Wickham et al., 1988). The diamicton belongs to the Tiskilwa Till member of the Wedron Formation and was deposited during the Wisconsinan glaciation. Horizontal flow is primarily in the coarse sandy/gravely clay unit, with limited penetration into the underlying tight clay (Figure 4). Hydraulic head and chemistry data (unreported) suggests leakage from the underlying clay into the coarse sandy/gravely clay unit.

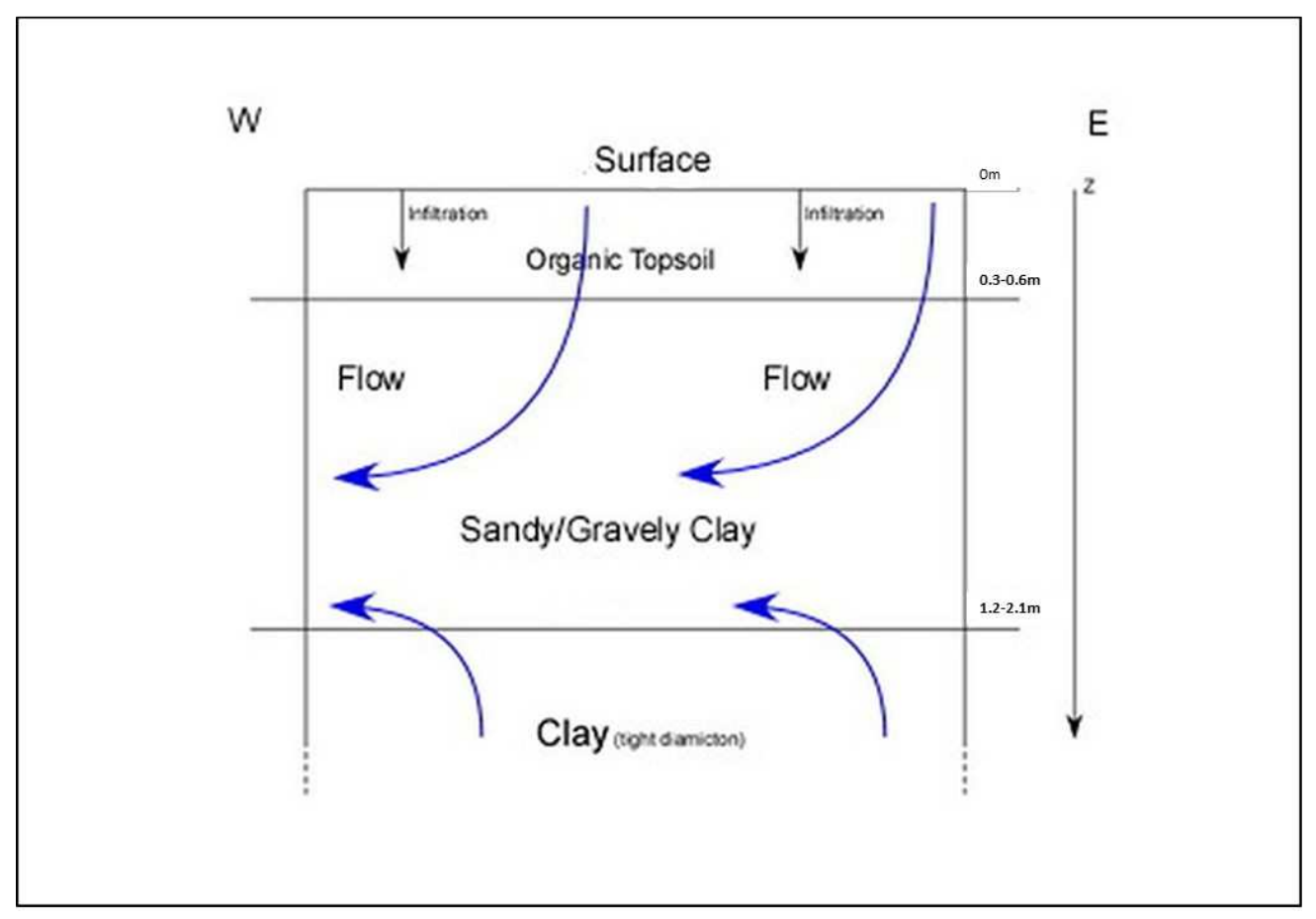

Figure 4. Conceptual model of subsurface flow. Groundwater flows in the sandy gravely clay unit from southeast to northwest. Organic topsoil is overlain by a sandy gravely clay unit, which is underlain by tight clay. The unconfined aquifer occupies the sandy gravely clay unit. 
This study site is subject to temperate climate. The 60-year average annual air temperature is $11.2^{\circ} \mathrm{C}$ with monthly average variance of $30^{\circ} \mathrm{C}$ depending on season (Changnon et al., 2004, Beach, 2008). Yearly average precipitation is $950 \mathrm{~mm} \pm 100 \mathrm{~mm}$ (Changnon et al., 2004), with 40-year monthly averages showing greatest precipitation in the spring and lowest precipitation in the winter (Changnon et al., 2004). 


\section{CHAPTER II: METHODS}

Sample events occurred weekly in well 4D for a year. Well 4D is $1.5 \mathrm{~m}$ deep and located near the perforated diversion pipes at site T3. Each sampling event included the collection of a sample every hour for 24-hours by an ISCO autosampler. Samples were stored in a refrigerator less than 24 hours before analysis. A DIONEX ICS-1100 ion chromatography system, owned by Illinois State University, was employed to analyze samples for nitrate as nitrogen $\left(\mathrm{NO}_{3}^{-}-\mathrm{N}\right)$ and chloride; a conservative tracer, chloride serves as a proxy for dilution. Samples were filtered using a $0.45 \mu \mathrm{m}$ pore space fiberglass filter to remove large particles before analysis by ion chromatography. Ion chromatography quality assurance and quality control techniques included blanks, duplicates, and standard replicates. Error was found to be $<1 \%$ with a relative standard deviation of $0.005 \mathrm{mg} / \mathrm{L}$. A Decagon groundwater depth, temperature, and conductance (DTC) sensor housed in the sample well recorded measurements every 15 minutes over the entire 24hour sampling period. A HOBO Pendant ${ }^{\circledR}$ temperature/light logger (UA-002-08) mounted on a metal stake collected air temperature $\left(-20^{\circ}-70^{\circ} \mathrm{C}\right)$ and light intensity $\left(0-30,000\right.$ lumens/ $\left./ \mathrm{ft}^{2}\right)$. Air temperature accuracy is $+/-0.53^{\circ} \mathrm{C}$ from $0^{\circ}-50^{\circ} \mathrm{C}$ and drifts less than $0.1^{\circ} \mathrm{C} /$ year. Dissolved oxygen concentration was measured before and after the sampling event with a YSI 85 .

Data analysis included t-tests for null hypotheses, and a Pearson correlation analysis for environmental factors. Seasons were defined by the 2017 solstices and equinoxes: Spring: March, 20 - June, 20; Summer: June, 21 - September, 21; Fall: September, 22 - December, 20; Winter: December, 21 - March, 19. For hypothesis 1, $\mathrm{H}_{0}$ : There will be no significant difference between $\left.\mu_{\max \left[\mathrm{NO}^{-}-\mathrm{N}\right]}\right)$ and $\mu_{\min \left[\mathrm{NO}^{-}-\mathrm{N}\right]}$ in each season was tested by a 1-tailed dependent groups ttest, $\alpha=0.05$. A one tailed t-test was used, as the alternative hypothesis is restricted to $\mu_{\max }\left[\mathrm{NO}^{-}-\mathrm{N}\right]$ $>\mu_{\min \left[\mathrm{NO}^{-}{ }^{-}\right]}\left(\right.$Ramsey \& Schafer, 2002). For hypothesis 2 and $3, \mathrm{H}_{0}$ : There will be no significant 
difference in $\mu_{\text {daily }}\left[\mathrm{NO}^{-}{ }^{-} \mathrm{N}\right]$ seasonally and $\mathrm{H}_{0}$ : There will be no significant difference between $\mu_{\text {difference }\left[\mathrm{NO}^{-}-\mathrm{N}\right]}$ among seasons were tested using a 2-tailed independent groups t-test, $\alpha=0.05$. A 2-tailed t-test was used here, as the alternative hypothesis is not restricted $\left(\mu_{1} \neq \mu_{2}\right)($ Ramsey \& Schafer, 2002). For hypothesis $4, \mathrm{H}_{0}$ : There will be no difference in the time-of-day when the maximum and minimum $\mathrm{NO}_{3}^{-}-\mathrm{N}$ concentration occurs among seasons was analyzed qualitatively by grouping hours into bins: hour 1-6 = bin 1, hour 7-12 = bin 2, hour 13-18= bin 3, hour 19-24 $=$ bin 4 . These bins were selected because bin 1 and 4 hold hours of darkness while bins 2 and 3 hold the photoperiod. Pearson correlations were 2-tailed, $\alpha=0.05$ (Ramsey $\&$ Schafer, 2002). 


\section{CHAPTER III: RESULTS}

\section{Nitrate-N data}

Thirty-three collection events were distributed over a year as follows: spring-13, summer9, fall-5, winter-6. From August 2016 to February $2017 \mathrm{NO}_{3}^{-}-\mathrm{N}$ concentrations remained between 1.5 and $3 \mathrm{mg} / \mathrm{L}$, then increased from February 2017 to late Mach 2017 where a peak of 6mg/L was reached (Figure 5). From March 2017 to May $2017 \mathrm{NO}_{3}{ }^{-}-\mathrm{N}$ concentrations decreased back down to between 1.5 and $3 \mathrm{mg} / \mathrm{L}$, but then again increased to $6 \mathrm{mg} / \mathrm{L}$ from June 2017 to August 2017 (Figure 5). Fewer samples were collected in fall due to a low water table and winter due to autosampler malfunction in low temperatures. Times of maximum and minimum $\mathrm{NO}_{3}{ }^{-} \mathrm{-N}$ concentration were divided into 4 groups of 6-hour intervals on a 24-hour scale (1=1:00am, 24=12:00am): hours 1-6, hours 7-12, hours 13-18, and hours 19-24. $\mathrm{NO}_{3}^{-}-\mathrm{N}$ concentration behavior over 24 hours followed 3 trends: 11 sinusoidal, 19 increase, and 2 decrease (Figure 6, Figure 14).

Over the entire duration of the study, the sampled waters have a mean daily $\mathrm{NO}_{3}^{-}-\mathrm{N}$ concentration ( $\mu_{\text {daily }\left[\mathrm{NO}^{-}{ }^{-} \mathrm{N}\right]}$ All $)$ of $3.52 \mathrm{mg} / \mathrm{L}$, a mean daily maximum $\mathrm{NO}_{3}{ }^{-}-\mathrm{N}$ concentration $\left(\mu_{\max }\right.$ $\left.\left[\mathrm{NO}^{-}-\mathrm{N}\right] \mathrm{All}\right)$ of $3.67 \mathrm{mg} / \mathrm{L}$, and a mean daily minimum $\mathrm{NO}_{3}{ }^{-}-\mathrm{N}$ concentration $\left(\mu_{\min }\left[\mathrm{NO}^{-}-\mathrm{N}\right] \mathrm{All}\right)$ of $3.15 \mathrm{mg} / \mathrm{L}$ (Table 1). The difference between maximum and minimum $\mathrm{NO}_{3}-\mathrm{N}$ concentration ( $\mu_{\text {difference }\left[\mathrm{NO}^{-}-\mathrm{N}\right]}$ ) is $0.52 \mathrm{mg} / \mathrm{L}$ (Table 1 ). The time of maximum $\mathrm{NO}_{3}{ }^{-}-\mathrm{N}$ concentration occurred most frequently hours 7-12, and the daily timing of minimum $\mathrm{NO}_{3}^{-}-\mathrm{N}$ concentration occurred most frequently hours 1-6 (Figure 7, Figure 8). When only days with a sinusoidal trend are considered, daily time of maximum $\mathrm{NO}_{3}-\mathrm{N}$ concentration occurred most frequently hours 1-6 $(\mathrm{n}=6)$, and the daily timing of minimum $\mathrm{NO}_{3}{ }^{-}-\mathrm{N}$ concentration occurred most frequently hours 13-18 (n=8) (Figure 9, Figure 10). 
Spring had a mean daily $\mathrm{NO}_{3}^{-}-\mathrm{N}$ concentration ( $\left.\mu_{\text {daily }\left[\mathrm{NO}^{-}-\mathrm{N}\right] \text { Spring }}\right)$ of $3.44 \mathrm{mg} / \mathrm{L}$, a mean daily maximum $\mathrm{NO}_{3}{ }^{-}-\mathrm{N}$ concentration $\left(\mu_{\max }\left[\mathrm{NO}^{-}{ }^{-} \mathrm{N}\right]\right.$ Spring $)$ of $3.59 \mathrm{mg} / \mathrm{L}$, and a mean daily minimum $\mathrm{NO}_{3}{ }^{-}-\mathrm{N}$ concentration $\left(\mu_{\min }\left[\mathrm{NO}^{-}-\mathrm{N}\right]\right.$ Spring $)$ of $2.98 \mathrm{mg} / \mathrm{L}$ (Figure 11, Figure 12) (Table 1). The difference between maximum and minimum $\mathrm{NO}_{3}{ }^{-}-\mathrm{N}$ concentration $\left(\mu_{\text {difference }\left[\mathrm{NO}^{-}{ }^{-} \mathrm{N}\right] \text { Spring }}\right)$ is $0.61 \mathrm{mg} / \mathrm{L}$ (Figure 13) (Table 1). The daily time of maximum $\mathrm{NO}_{3}{ }^{-}-\mathrm{N}$ concentration occurred most frequently hours 1-6 $(n=4)$ and hours 7-12 $(n=4)$, and the daily timing of minimum $\mathrm{NO}_{3}^{-}-\mathrm{N}$ concentration occurred most frequently between hours 13-18 (n=9) (Figure 7, Figure 8). $\mathrm{NO}_{3}^{-}-\mathrm{N}$ concentration behavioral trends included 6 sinusoidal, 6 increase, and 1 decrease (Figure 14). When only days with a sinusoidal trend are considered, daily time of maximum $\mathrm{NO}_{3}{ }^{-}-\mathrm{N}$ concentration occurred most frequently hours 1-6 $(n=2)$ and 19-24 $(n=3)$, and the daily timing of minimum $\mathrm{NO}_{3}{ }^{-}-\mathrm{N}$ concentration occurred most frequently hours 13-18 $(n=5)$ (Figure 9, Figure $10)$.

Summer had a mean daily $\mathrm{NO}_{3}{ }^{-}-\mathrm{N}$ concentration $\left(\mu_{\text {daily }}\left[\mathrm{NO}^{-}{ }^{-} \mathrm{N}\right]\right.$ Summer$)$ of $4.63 \mathrm{mg} / \mathrm{L}$, a mean daily maximum $\mathrm{NO}_{3}{ }^{-}-\mathrm{N}$ concentration $\left(\mu_{\max }\left[\mathrm{NO}^{-}{ }^{-} \mathrm{N}\right]\right.$ Summer$)$ of $4.81 \mathrm{mg} / \mathrm{L}$, and a mean daily minimum $\mathrm{NO}_{3}{ }^{-}-\mathrm{N}$ concentration $\left(\mu_{\min }\left[\mathrm{NO}^{-}{ }^{-} \mathrm{N}\right]\right.$ Summer$)$ of $4.25 \mathrm{mg} / \mathrm{L}$ (Figure 11, Figure 12) (Table 1). The difference between maximum and minimum $\mathrm{NO}_{3}{ }^{-}-\mathrm{N}$ concentration $\left(\mu_{\text {difference }\left[\mathrm{NO}^{-}-\mathrm{N}\right]}\right.$ Summer) is $0.56 \mathrm{mg} / \mathrm{L}$ (Figure 13) (Table 1). The daily time of maximum $\mathrm{NO}_{3}{ }^{-}-\mathrm{N}$ concentration occurred most frequently hours 7-12 $(n=6)$, and the daily timing of minimum $\mathrm{NO}_{3}{ }^{-}-\mathrm{N}$ concentration occurred most frequently hours 7-12 (n=5) (Figure 7, Figure 8). $\mathrm{NO}_{3}^{-}-\mathrm{N}$ concentration behavioral trends included 1 sinusoidal, 7 increase, and 1 decrease (Figure 14). When only days with a sinusoidal trend are considered, daily time of maximum $\mathrm{NO}_{3}^{-}-\mathrm{N}$ concentration occurred hours 1-6 (n=1), and the daily timing of minimum $\mathrm{NO}_{3}^{-}-\mathrm{N}$ concentration occurred hours 19-24 (n=1) (Figure 9, Figure 10). 
Fall had a mean daily $\mathrm{NO}_{3}^{-}-\mathrm{N}$ concentration ( $\mu_{\text {daily }}\left[\mathrm{NO}^{-}{ }^{-} \mathrm{N}\right]$ Fall) of $2.18 \mathrm{mg} / \mathrm{L}$, a mean daily maximum $\mathrm{NO}_{3}{ }^{-}-\mathrm{N}$ concentration $\left(\mu_{\max }\left[\mathrm{NO}^{-}-\mathrm{N}\right.\right.$ ] Fall $)$ of $2.33 \mathrm{mg} / \mathrm{L}$, and a mean daily minimum $\mathrm{NO}_{3}{ }^{-}$ -N concentration $\left(\mu_{\min }\left[\mathrm{NO}^{-}{ }^{-} \mathrm{N}\right]\right.$ Fall $)$ of $1.93 \mathrm{mg} / \mathrm{L}$ (Figure 11, Figure 12) (Table 1). The difference between maximum and minimum $\mathrm{NO}_{3}{ }^{-}-\mathrm{N}$ concentration $\left(\mu_{\text {difference }}\left[\mathrm{NO}^{-}{ }^{-} \mathrm{N}\right]\right.$ Fall $)$ is $0.41 \mathrm{mg} / \mathrm{L}$ (Figure 13) (Table 1). The daily time of maximum $\mathrm{NO}_{3}{ }^{-}-\mathrm{N}$ concentration occurred most frequently hours 1-6 $(\mathrm{n}=2)$ and 13-18 $(\mathrm{n}=2)$, and the daily timing of minimum $\mathrm{NO}_{3}^{-}-\mathrm{N}$ concentration occurred most frequently hours 13-18 $(\mathrm{n}=4)$ (Figure 7, Figure 8). $\mathrm{NO}_{3}{ }^{-}-\mathrm{N}$ concentration behavioral trends included 3 sinusoidal, 2 increase, and no decreases (Figure 14). When only days with a sinusoidal trend are considered, daily time of maximum $\mathrm{NO}_{3}{ }^{-}-\mathrm{N}$ concentration occurred most frequently hours 1-6 $(n=2)$, and the daily timing of minimum $\mathrm{NO}_{3}{ }^{-}-$ N concentration occurred most frequently hours 13-18 $(n=2)$ (Figure 9, Figure 10).

Winter had a mean daily $\mathrm{NO}_{3}{ }^{-}-\mathrm{N}$ concentration $\left(\mu_{\text {daily }}\left[\mathrm{NO}^{-}{ }^{-} \mathrm{N}\right]\right.$ Winter $)$ of $3.11 \mathrm{mg} / \mathrm{L}$, a mean daily maximum $\mathrm{NO}_{3}{ }^{-}-\mathrm{N}$ concentration $\left(\mu_{\max }\left[\mathrm{NO}^{-}{ }^{-} \mathrm{N}\right]\right.$ Winter $)$ of $3.25 \mathrm{mg} / \mathrm{L}$, and a mean daily minimum $\mathrm{NO}_{3}^{-}-\mathrm{N}$ concentration $\left(\mu_{\min }\left[\mathrm{NO}^{-}-\mathrm{N}\right]\right.$ Winter) of $2.87 \mathrm{mg} / \mathrm{L}$ (Figure 11, Figure 12) (Table 1). The difference between maximum and minimum $\mathrm{NO}_{3}^{-}-\mathrm{N}$ concentration $\left(\mu_{\text {difference }\left[\mathrm{NO}^{-}-\mathrm{N}\right]}\right.$ Winter $)$ is $0.38 \mathrm{mg} / \mathrm{L}$ (Figure 13) (Table 1). The daily time of maximum $\mathrm{NO}_{3}{ }^{-}-\mathrm{N}$ concentration occurred most frequently hours 1-6 $(\mathrm{n}=3)$, and the daily timing of minimum $\mathrm{NO}_{3}{ }^{-}-\mathrm{N}$ concentration occurred most frequently hours 13-18 ( $\mathrm{n}=3$ ) (Figure 7, Figure 8). $\mathrm{NO}_{3}^{-}-\mathrm{N}$ concentration behavioral trends included 1 sinusoidal, 4 increases, and no decreases (Figure 14). When only days with a sinusoidal trend are considered, daily time of maximum $\mathrm{NO}_{3}^{-}-\mathrm{N}$ concentration occurred most frequently hours 1-6 (n=1), and the daily timing of minimum $\mathrm{NO}_{3}^{-}-\mathrm{N}$ concentration occurred most frequently hours 13-18 $(\mathrm{n}=1)$ (Figure 9, Figure 10). 


\section{Statistical Analyses of Nitrate-N Data}

All seasons show a statistically significant difference between their respective $\mu_{\max }\left[\mathrm{NO}^{-}-\mathrm{N}\right]$

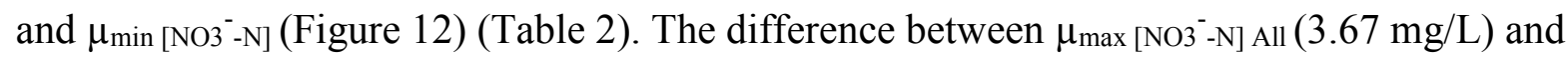
$\mu_{\min \left[\mathrm{NO}^{-}{ }^{-} \mathrm{N}\right] \text { All }}(3.15 \mathrm{mg} / \mathrm{L})$ is statistically significant $(t(32)=5.69, p<0.01)$. The difference between $\mu_{\max \left[\mathrm{NO}^{-}-\mathrm{N}\right] \text { Spring }}(3.59 \mathrm{mg} / \mathrm{L})$ and $\mu_{\min \left[\mathrm{NO}^{-}-\mathrm{N}\right] \text { Spring }}(2.98 \mathrm{mg} / \mathrm{L})$ is statistically significant $(t(12)=2.76, p=0.01)$ (Figure 12) (Table 2). The difference between $\mu_{\max \left[\mathrm{NO}^{-}-\mathrm{N}\right] \text { Summer }}(4.81$ $\mathrm{mg} / \mathrm{L})$ and $\mu_{\min }\left[\mathrm{NO}^{-}{ }^{-} \mathrm{N}\right]$ Summer $(4.25 \mathrm{mg} / \mathrm{L})$ is statistically significant $(t(8)=6.83, p<0.01)$ (Figure 12) (Table 2). The difference between $\mu_{\max \left[\mathrm{NO}^{-}-\mathrm{N}\right] \text { Fall }}(2.33 \mathrm{mg} / \mathrm{L})$ and $\mu_{\min \left[\mathrm{NO}^{-}-\mathrm{N}\right] \text { Fall }}(1.93 \mathrm{mg} / \mathrm{L})$ is statistically significant $(t(4)=4.34, p=0.01)$ (Figure 12) (Table 2). The difference between $\mu_{\max }$

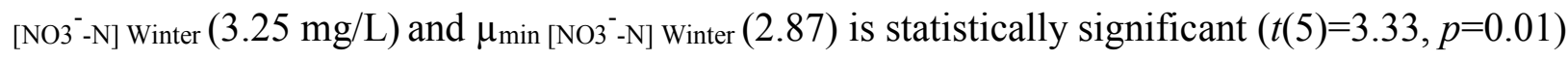
(Figure 12) (Table 2). The $\mu_{\text {difference }\left[\mathrm{NO}^{-}-\mathrm{N}\right]}$ is greatest in the summer $(0.61 \mathrm{mg} / \mathrm{L})$ and lowest in the winter $(0.38 \mathrm{mg} / \mathrm{L})$ (Figure 13$)$. However, there are no statistically significant differences between any season combinations (Figure 13) (Table 3).

Two seasonal comparisons show a statistically significant difference between the mean daily $\mathrm{NO}_{3}{ }^{-}-\mathrm{N}$ concentration (Figure 11) (Table 4). The concentration difference between $\mu_{\text {daily }}$ $\left[\mathrm{NO}^{-}{ }^{-} \mathrm{N}\right]$ Spring $(3.44 \mathrm{mg} / \mathrm{L})$ and $\mu_{\text {daily }\left[\mathrm{NO}^{-}-\mathrm{N}\right] \text { Fall }}(2.18 \mathrm{mg} / \mathrm{L})$ is statistically significant $(t(15.90)=2.70, p=0.02)($ Figure 11$)($ Table 4$)$. The difference between $\mu_{\text {daily }\left[\mathrm{NO}^{-}{ }^{-} \mathrm{N}\right]}$ Summer $(4.63$ $\mathrm{mg} / \mathrm{L})$ and $\mu_{\text {daily }\left[\mathrm{NO}^{-}{ }^{-} \mathrm{N}\right] \text { Fall }}(2.18 \mathrm{mg} / \mathrm{L})$ is statistically significant $(t(10.91)=4.83, p<0.01)$. SpringSummer, Spring-Winter, Summer-Winter, and Fall-Winter combinations are not statistically different (Figure 11) (Table 4). 
Table 1

$\mathrm{NO}_{3}{ }^{-}-\mathrm{N}$ Concentration Mean \pm Standard Deviation by Season

\begin{tabular}{ccccc}
\hline Season & $\begin{array}{c}\mu_{\text {daily }\left[\mathrm{NO}^{-} \mathrm{-}\right]} \\
(\mathrm{mg} / \mathrm{L})\end{array}$ & $\begin{array}{c}\mu_{\max \left[\mathrm{NO}^{-}-\mathrm{N}\right]} \\
(\mathrm{mg} / \mathrm{L})\end{array}$ & $\begin{array}{c}\mu_{\min \left[\mathrm{NO}^{-}-\mathrm{N}\right]} \\
(\mathrm{mg} / \mathrm{L})\end{array}$ & $\begin{array}{c}\mu_{\text {difference }\left[\mathrm{NO}^{-}{ }^{-} \mathrm{N}\right]} \\
(\mathrm{mg} / \mathrm{L})\end{array}$ \\
\hline Spring $(\mathrm{n}=13)$ & $3.45 \pm 1.50$ & $3.59 \pm 1.54$ & $2.98 \pm 1.52$ & $0.61 \pm 0.79$ \\
Summer (n=9) & $4.63 \pm 1.38$ & $4.81 \pm 1.41$ & $4.25 \pm 1.34$ & $0.56 \pm 0.25$ \\
Fall (n=5) & $2.18 \pm 0.49$ & $2.33 \pm 0.47$ & $1.93 \pm 0.57$ & $0.41 \pm 0.21$ \\
Winter (n=6) & $3.11 \pm 1.37$ & $3.25 \pm 1.45$ & $2.87 \pm 1.19$ & $0.38 \pm 0.28$ \\
All Seasons & $3.52 \pm 1.52$ & $3.67 \pm 1.55$ & $3.15 \pm 1.47$ & $0.52 \pm 0.53$ \\
(n=33) & & & &
\end{tabular}

Note. $\mu_{\text {daily }\left[\mathrm{NO}^{-}{ }^{-} \mathrm{N}\right]}$ represents mean daily concentration for the season. $\mu_{\max \left[\mathrm{NO}^{-}-\mathrm{N}\right]}$ represents the mean maximum concentration for the season. $\mu_{\min }\left[\mathrm{NO}^{-}{ }^{-} \mathrm{N}\right]$ represents the mean minimum concentration for the season. $\mu_{\text {difference }\left[\mathrm{NO}^{-}-\mathrm{N}\right]}$ represents the mean difference between the 24-hour maximum and minimum for the season. 
Table 2

t-test Results for Statistically Significant Difference Between $\mu_{\max }\left[\mathrm{NO}^{-}{ }_{-\mathrm{N}]}\right.$ and $\mu_{\min }\left[\mathrm{NO}^{-}{ }_{-}^{-}\right]$

Difference Statistics
$\mu_{\max \left[\mathrm{NO}^{-}{ }^{-} \mathrm{N}\right] \text { Spring }} \neq \mu_{\min }\left[\mathrm{NO}^{-}{ }^{-} \mathrm{N}\right]$ Spring
$(t(12)=2.76, p=0.01)$
$\mu_{\max \left[\mathrm{NO}^{-}{ }^{-} \mathrm{N}\right] \text { Summer }} \neq \mu_{\min }\left[\mathrm{NO}^{-}{ }^{-} \mathrm{N}\right]$ Summer
$(t(8)=6.83, p<0.01)$
$\mu_{\max \left[\mathrm{NO}^{-}-\mathrm{N}\right] \text { Fall }} \neq \mu_{\min \left[\mathrm{NO}^{-}-\mathrm{N}\right] \text { Fall }}$
$(t(4)=4.34, p=0.01)$

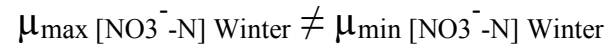
$(t(5)=3.33, p=0.01)$

Note. Significance indicated in bold. 


\section{Table 3}

t-test Results for Statistically Significant Difference Between $\mu_{\text {difference }\left[{ }^{N O}{ }^{-}{ }^{-N}\right] \text { season }}$ and $\mu_{\text {difference }}$ $\left[\mathrm{NO}^{-}-\mathrm{N}\right]$ season

\begin{tabular}{|c|c|c|c|c|}
\hline & $\mu_{\text {difference }\left[\mathrm{NO}^{-}{ }^{-} \mathrm{N}\right]}$ & $\mu_{\text {difference }\left[\mathrm{NO}^{-}-\mathrm{N}\right]}$ & $\mu_{\text {difference }\left[\mathrm{NO}^{-}-\mathrm{N}\right]}$ & $\mu_{\text {difference }\left[\mathrm{NO}^{-}-\mathrm{N}\right]}$ \\
\hline & Spring & Summer & Fall & Winter \\
\hline$\mu_{\text {difference }\left[\mathrm{NO}^{-}-\mathrm{N}\right]}$ & - & $(t(15.14)=0.19$, & $(t(16)=0.55$ & $(t(17)=0.68$ \\
\hline Spring & & $p=0.85)$ & $p=0.59)$ & $p=0.51)$ \\
\hline$\mu_{\text {difference }\left[\mathrm{NO}^{-}-\mathrm{N}\right]}$ & - & - & $(t(12)=0.19$ & $(t(13)=1.35$ \\
\hline Summer & & & $p=0.26)$ & $p=0.20)$ \\
\hline$\mu_{\text {difference }\left[\mathrm{NO}^{-}-\mathrm{N}\right]}$ & - & - & - & $(t(9)=0.19$ \\
\hline Fall & & & & $p=0.85)$ \\
\hline$\mu_{\text {difference }\left[\mathrm{NO}^{-}{ }^{-} \mathrm{N}\right]}$ & - & - & - & - \\
\hline Winter & & & & \\
\hline
\end{tabular}

Note. No significant differences. 
Table 4.

t-test Results for Statistically Significant Difference Between $\mu_{\text {daily }\left[\mathrm{NO}^{-}{ }^{-} \mathrm{N}\right] \text { season }}$ and $\mu_{\text {daily }}\left[\mathrm{NO}^{-}{ }^{-} \mathrm{N}\right]$

\begin{tabular}{|c|c|c|c|c|}
\hline & $\mu_{\text {daily }\left[\mathrm{NO}^{-}-\mathrm{N}\right]}$ & $\mu_{\text {daily }\left[\mathrm{NO}^{-}-\mathrm{N}\right]}$ & $\mu_{\text {daily }\left[\mathrm{NO}^{-}-\mathrm{N}\right]}$ & $\mu_{\text {daily }\left[\mathrm{NO}^{-}-\mathrm{N}\right]}$ \\
\hline & Spring & Summer & Fall & Winter \\
\hline$\mu_{\text {daily }\left[\mathrm{NO}^{-}{ }^{-} \mathrm{N}\right]}$ & - & $(t(20)=-1.89$ & $(t(15.90)=2.70$ & $(t(17)=0.46$ \\
\hline Spring & & $p=0.07)$ & $p=0.02)$ & $p=0.65)$ \\
\hline$\mu_{\text {daily }\left[\mathrm{NO}^{-}-\mathrm{N}\right]}$ & - & - & $(t(10.91)=4.83$ & $(t(13)=2.10$ \\
\hline Summer & & & $p<0.01)$ & $p=0.06)$ \\
\hline$\mu_{\text {daily }\left[\mathrm{NO3}^{-} \mathrm{-N}\right]}$ & - & - & - & $(t(9)=-1.44$ \\
\hline Fall & & & & $p=0.19)$ \\
\hline$\mu_{\text {daily }\left[\mathrm{NO}^{-}-\mathrm{N}\right]}$ & - & - & - & - \\
\hline Winter & & & & \\
\hline
\end{tabular}

Note. Significance indicated in bold. 


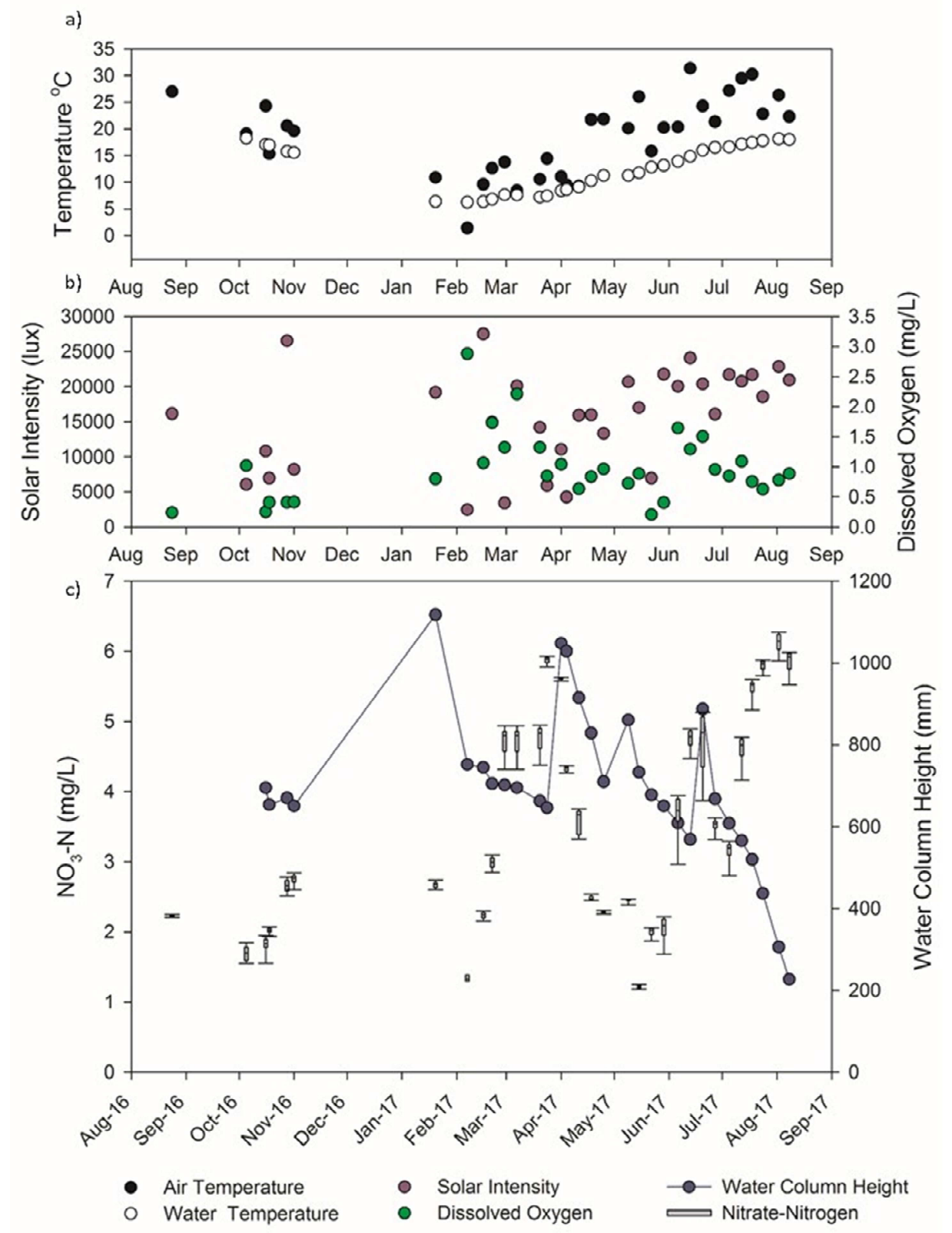

Figure 5. $\mathrm{NO}_{3}^{-}-\mathrm{N}$ concentrations and environmental factors observed during the 24-hour collection periods. A) mean air temperature and mean groundwater temperature; B) mean solar intensity and dissolved oxygen; C) $\mathrm{NO}_{3}{ }^{-}-\mathrm{N}$ concentration and mean water column height. The ends of the boxes represent the $25^{\text {th }}$ and $75^{\text {th }}$ percentiles with the solid line at the median and the dashed line at the mean; the error bars depict the $10^{\text {th }}$ and $90^{\text {th }}$ percentiles and the points represent the $5^{\text {th }}$ and $95^{\text {th }}$ percentiles. 

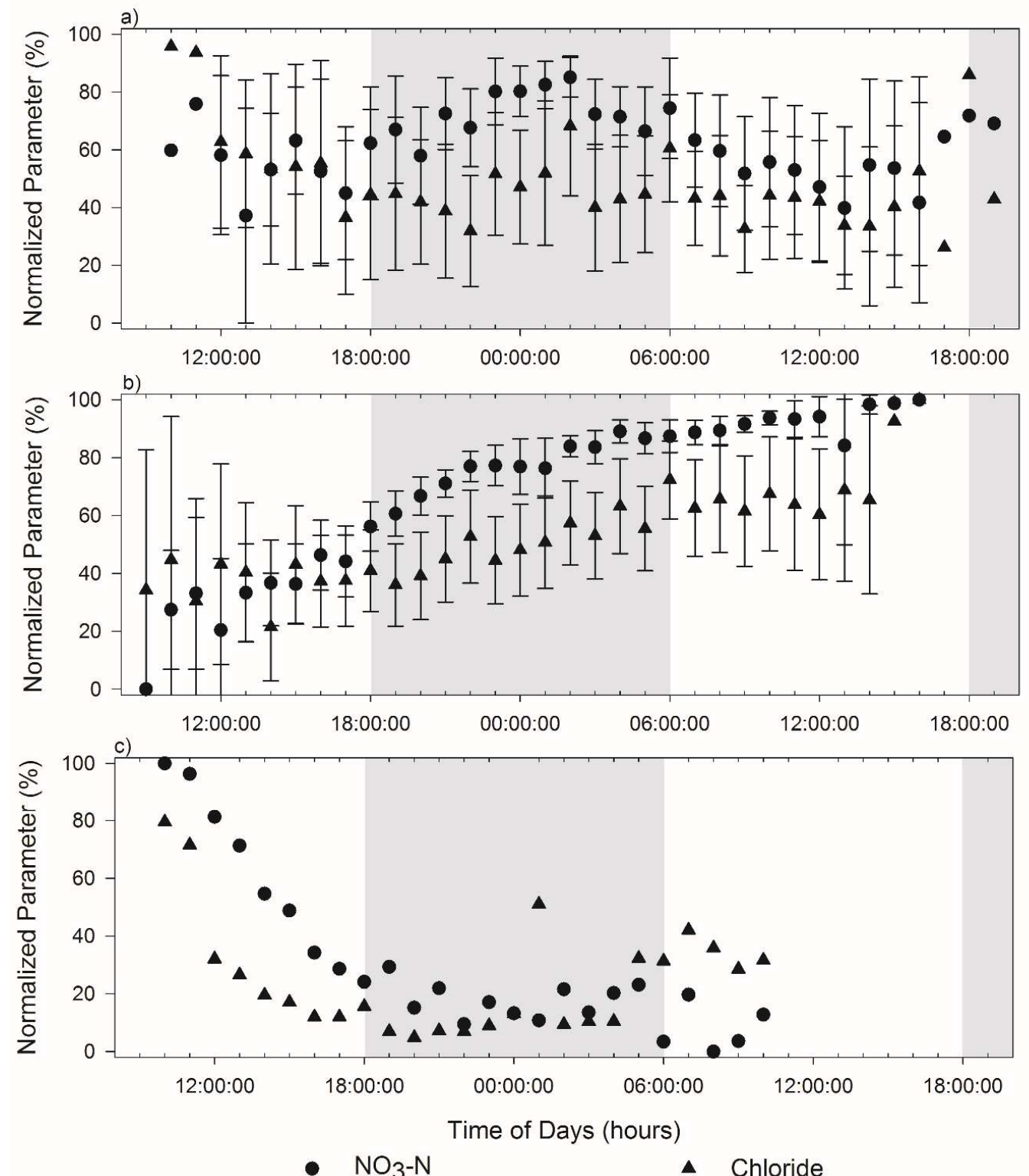

Figure 6. Time series trends for normalized $\left[\mathrm{NO}_{3}^{-}-\mathrm{N}\right]$ ( circle) and $\left[\mathrm{Cl}^{-}\right]$(triangle) over the course of the study. Grey area indicates the dark period and white area indicates the photoperiod. Points 
are the mean and error bars are one standard deviation. A) Sinusoidal trend B) Increase trend C) Decrease trend.

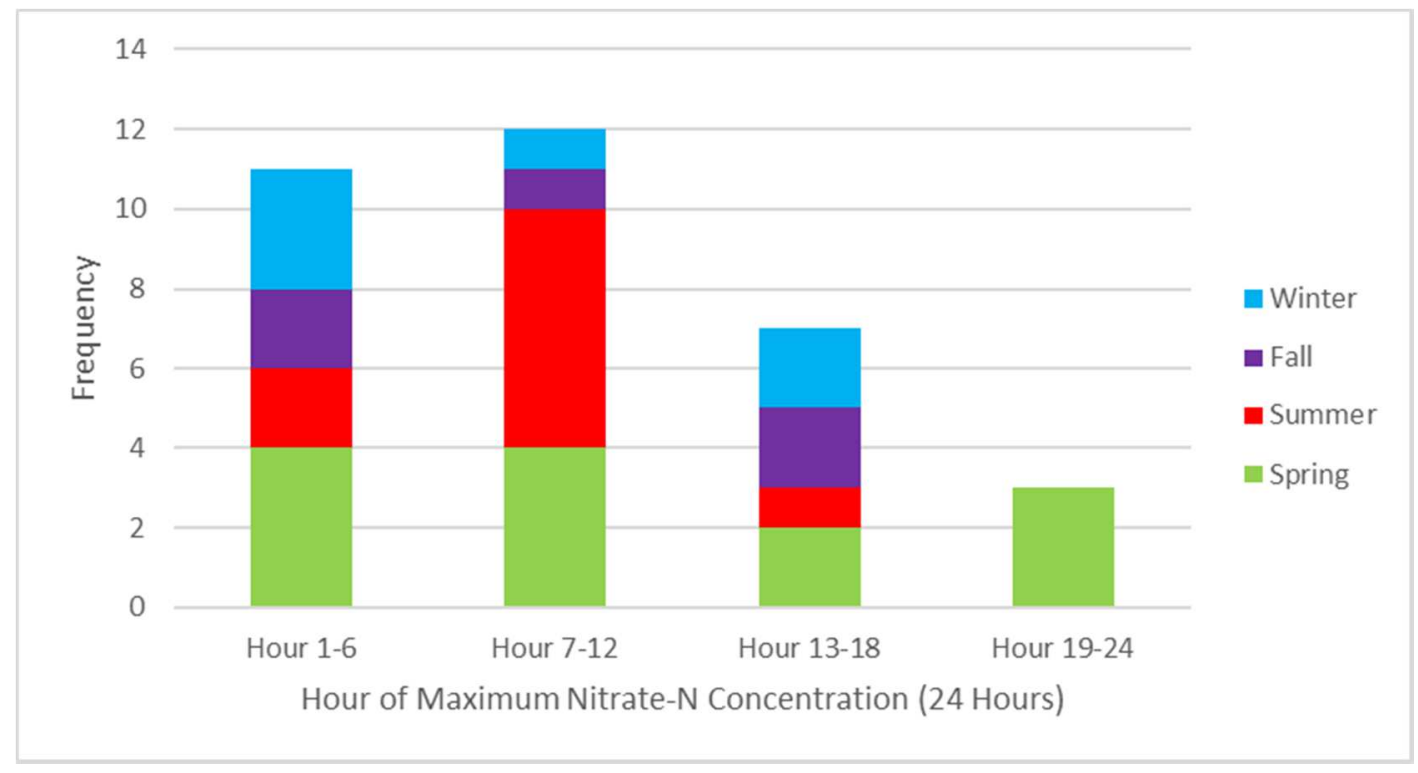

Figure 7. Bar graph displaying frequency of maximum $\mathrm{NO}_{3}{ }^{-}-\mathrm{N}$ concentration by time-of-day for increase, decrease, and sinusoidal trends.

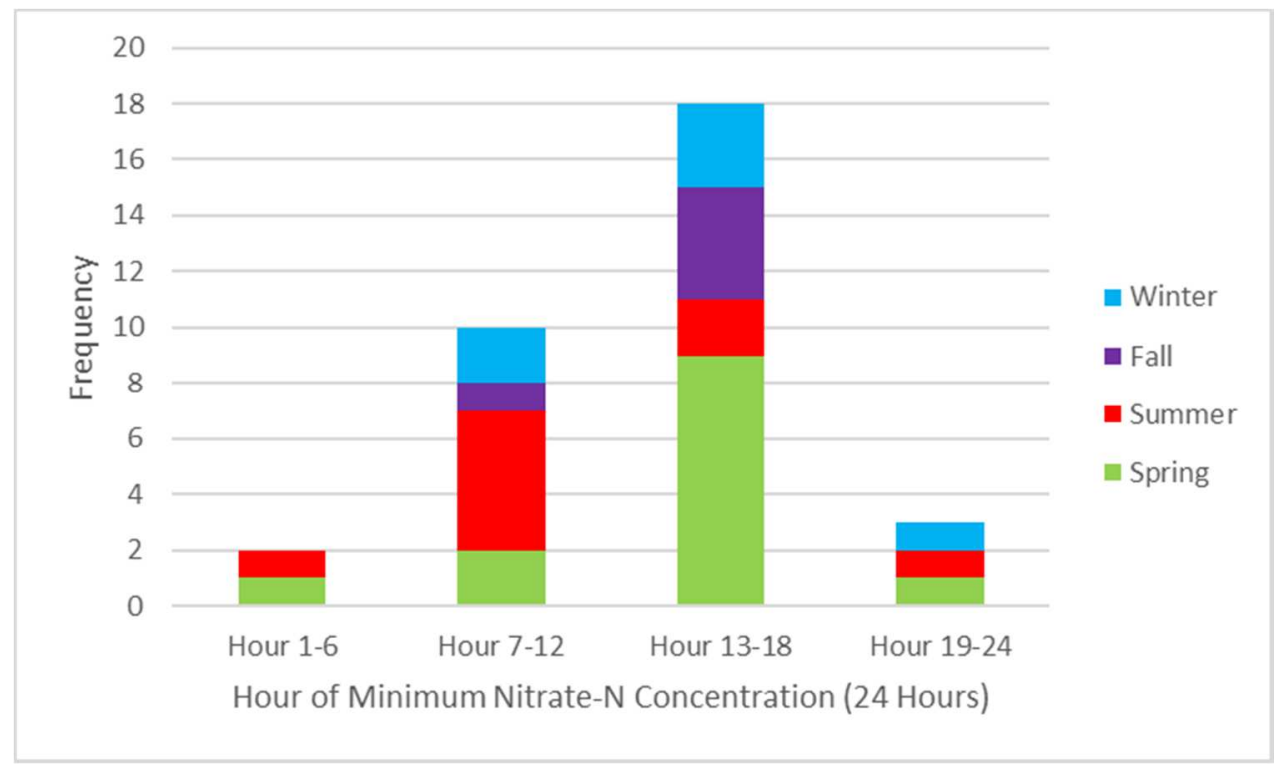

Figure 8. Bar graph displaying frequency of minimum $\mathrm{NO}_{3}{ }^{-} \mathrm{N}$ concentration by time-of-day for increase, decrease, and sinusoidal trends. 


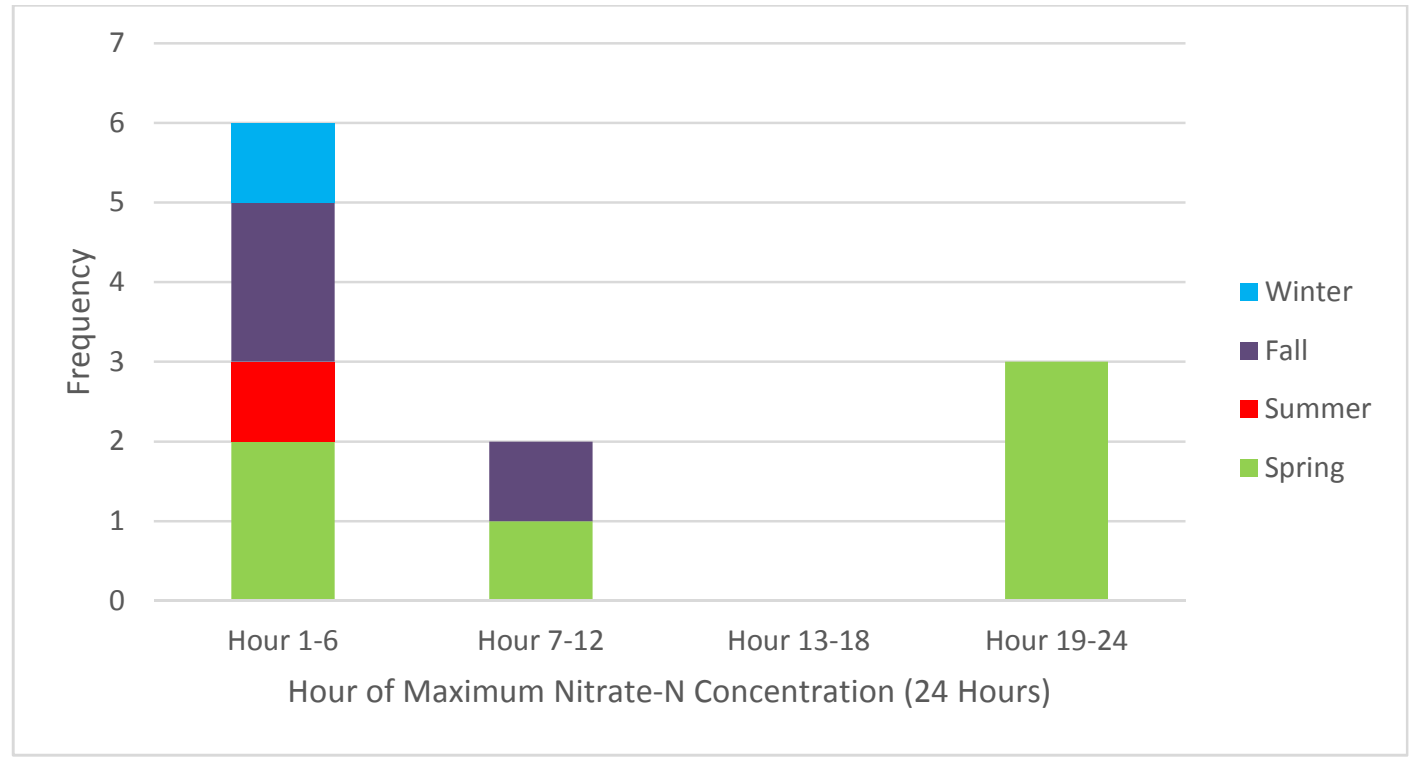

Figure 9. Bar graph displaying frequency of maximum $\mathrm{NO}_{3}{ }^{-}-\mathrm{N}$ concentration by time-of-day for sinusoidal trends.

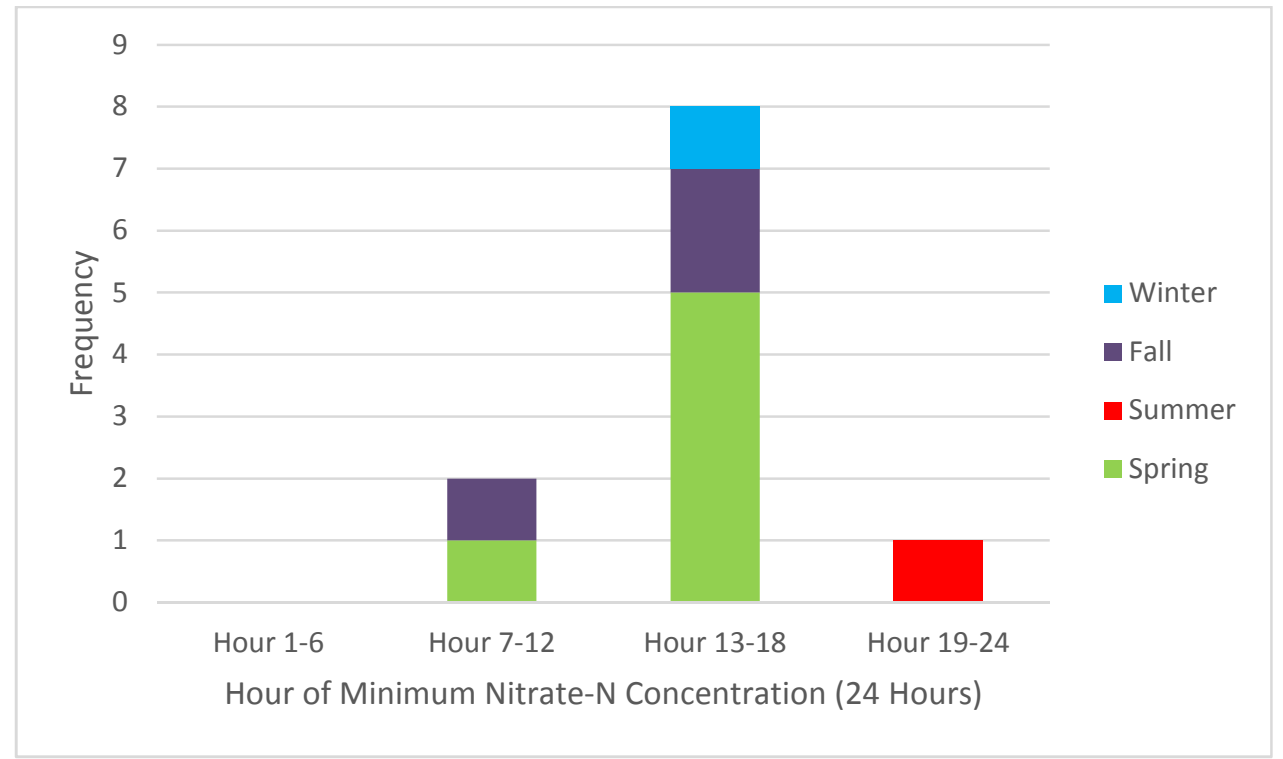

Figure 10. Bar graph displaying frequency of minimum $\mathrm{NO}_{3}^{-}-\mathrm{N}$ concentration by time-of-day for sinusoidal trends. 


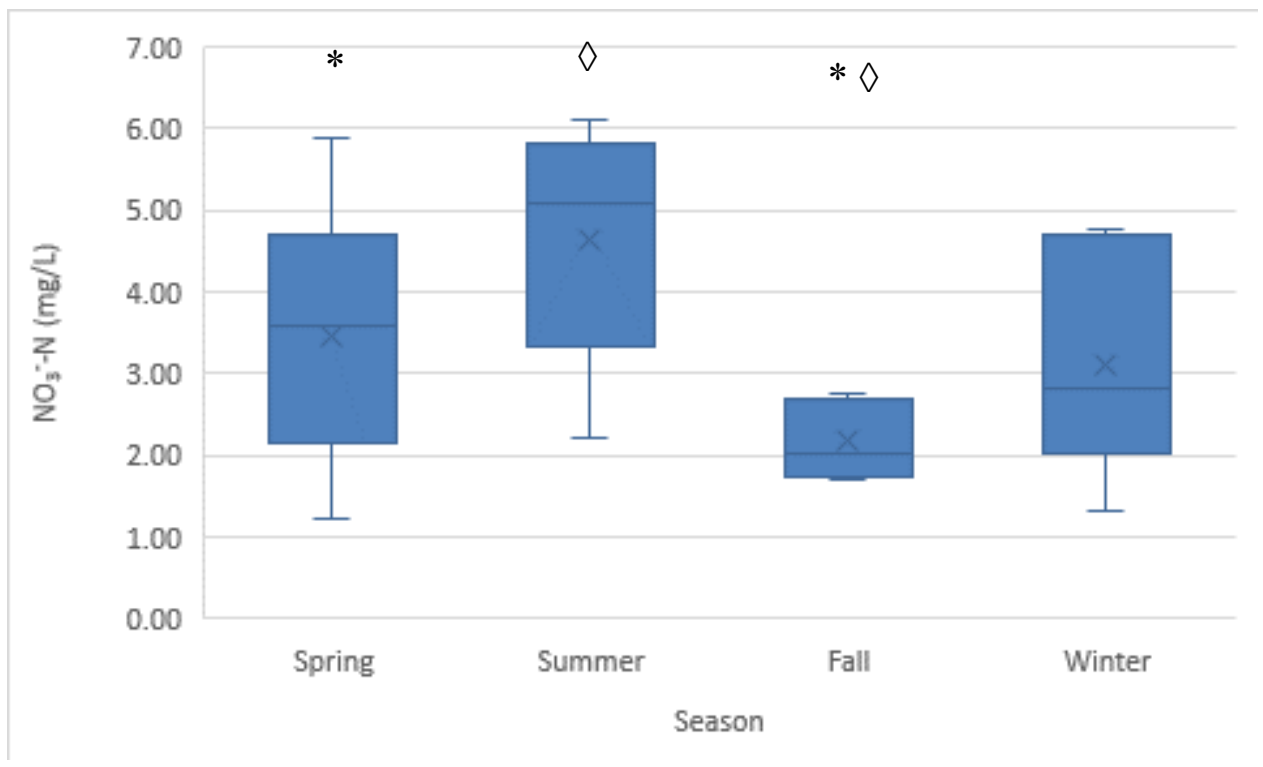

Figure 11. Daily $\mathrm{NO}_{3}^{-}-\mathrm{N}$ concentration by season. Statistically significant difference between seasonal $\mu_{\text {daily }\left[\mathrm{NO}^{-}-\mathrm{N}\right]}$ indicated by $*$ and $\diamond$. The ends of the boxes represent the $25^{\text {th }}$ and $75^{\text {th }}$ percentiles with the solid line at the median and the " $\mathrm{X}$ " at the mean; the error bars depict the $10^{\text {th }}$ and $90^{\text {th }}$ percentiles. 


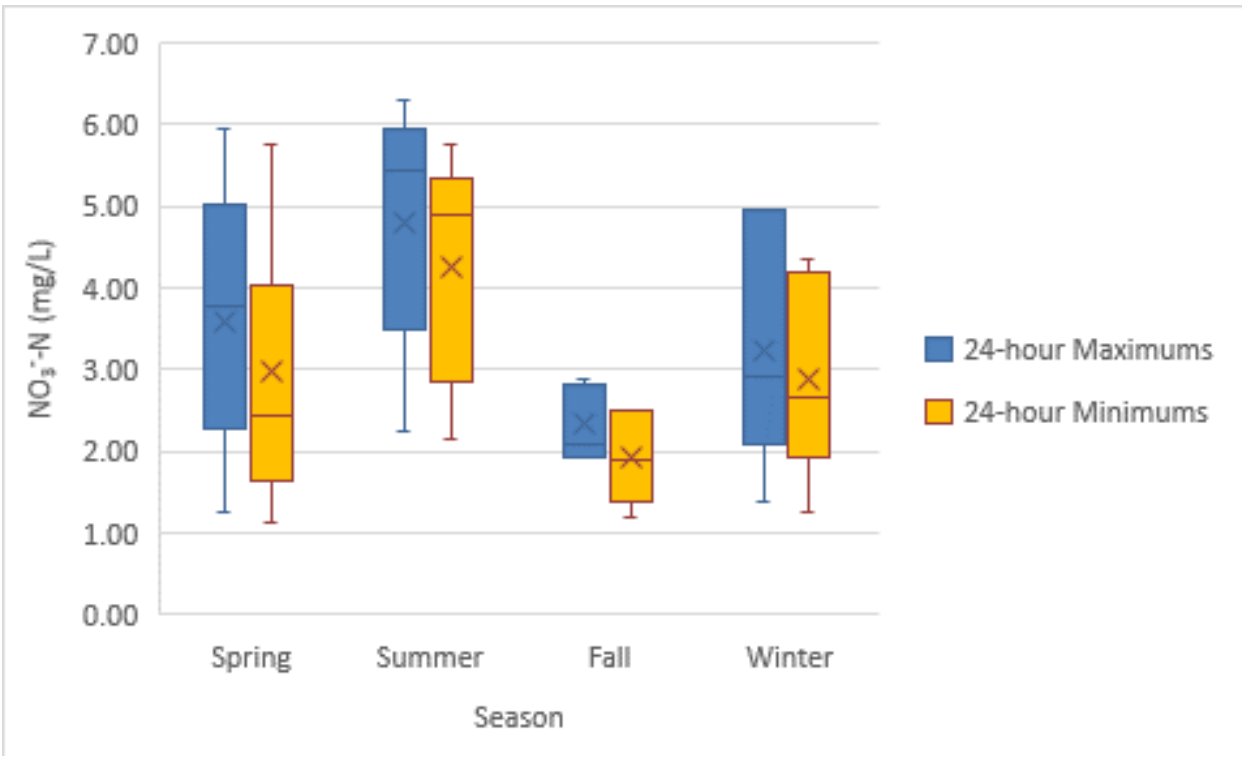

Figure 12. Daily maximum and minimum $\mathrm{NO}_{3}{ }^{-}-\mathrm{N}$ concentrations for each season. For each

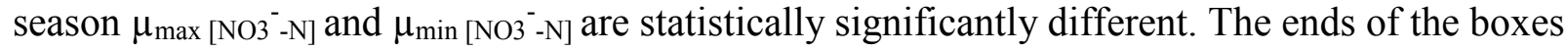
represent the $25^{\text {th }}$ and $75^{\text {th }}$ percentiles with the solid line at the median and the " $X$ " at the mean; the error bars depict the $10^{\text {th }}$ and $90^{\text {th }}$ percentiles. 


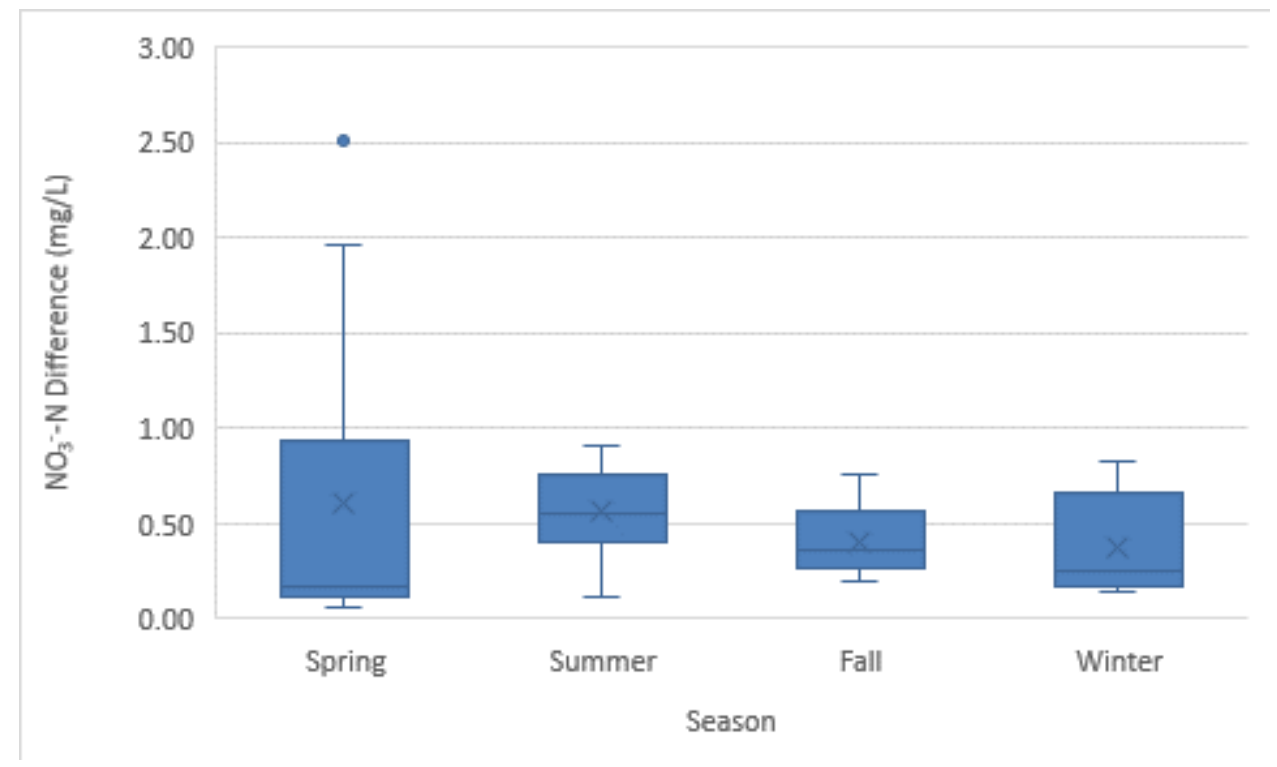

Figure 13. Box and whisker plots for the differences between daily maximum and minimum $\mathrm{NO}_{3}{ }^{-}-\mathrm{N}$ concentration for each season. No statistically significant differences in $\mu_{\text {difference }\left[\mathrm{NO}^{-}{ }^{-} \mathrm{N}\right]}$ are present among seasons. The ends of the boxes represent the $25^{\text {th }}$ and $75^{\text {th }}$ percentiles with the solid line at the median and the " $\mathrm{X}$ " at the mean; the error bars depict the $10^{\text {th }}$ and $90^{\text {th }}$ percentiles; the points depict the outliers. 


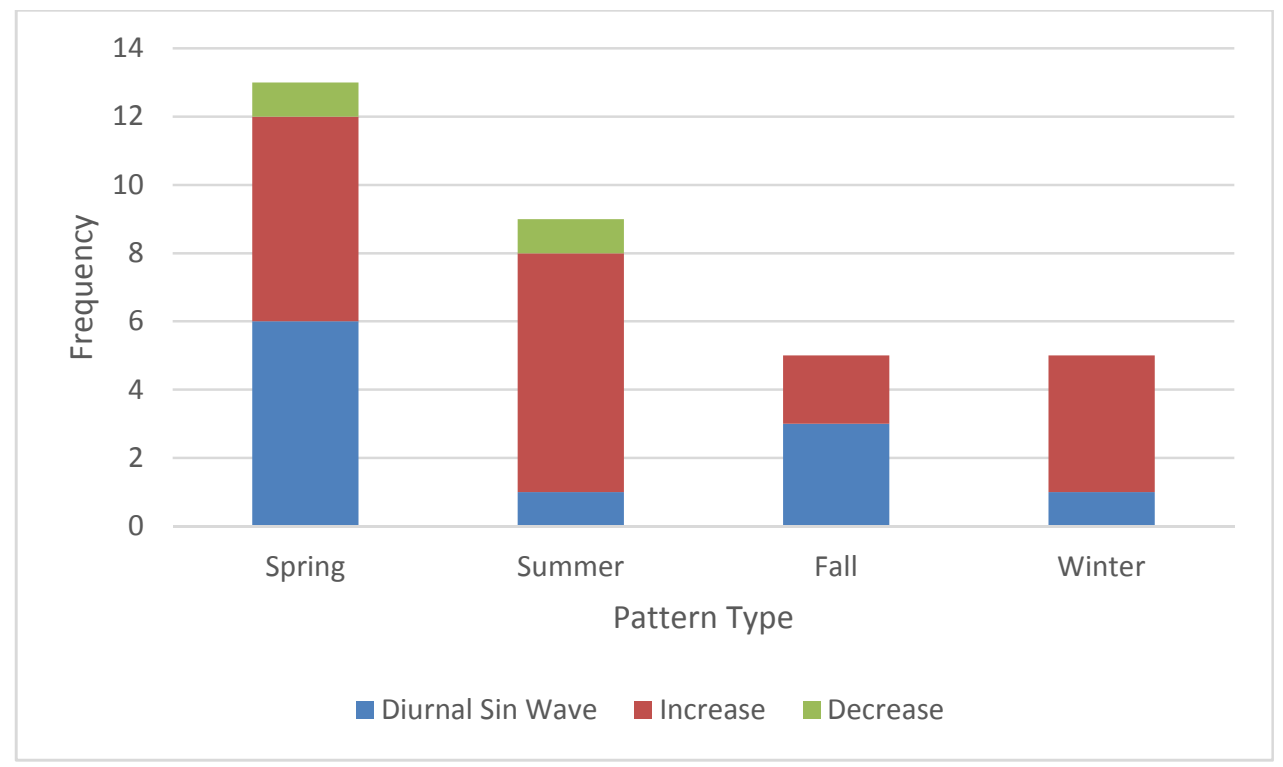

Figure 14. Frequency of $\mathrm{NO}_{3}^{-}-\mathrm{N}$ concentration increase, decrease, and sinusoidal trends by season. 

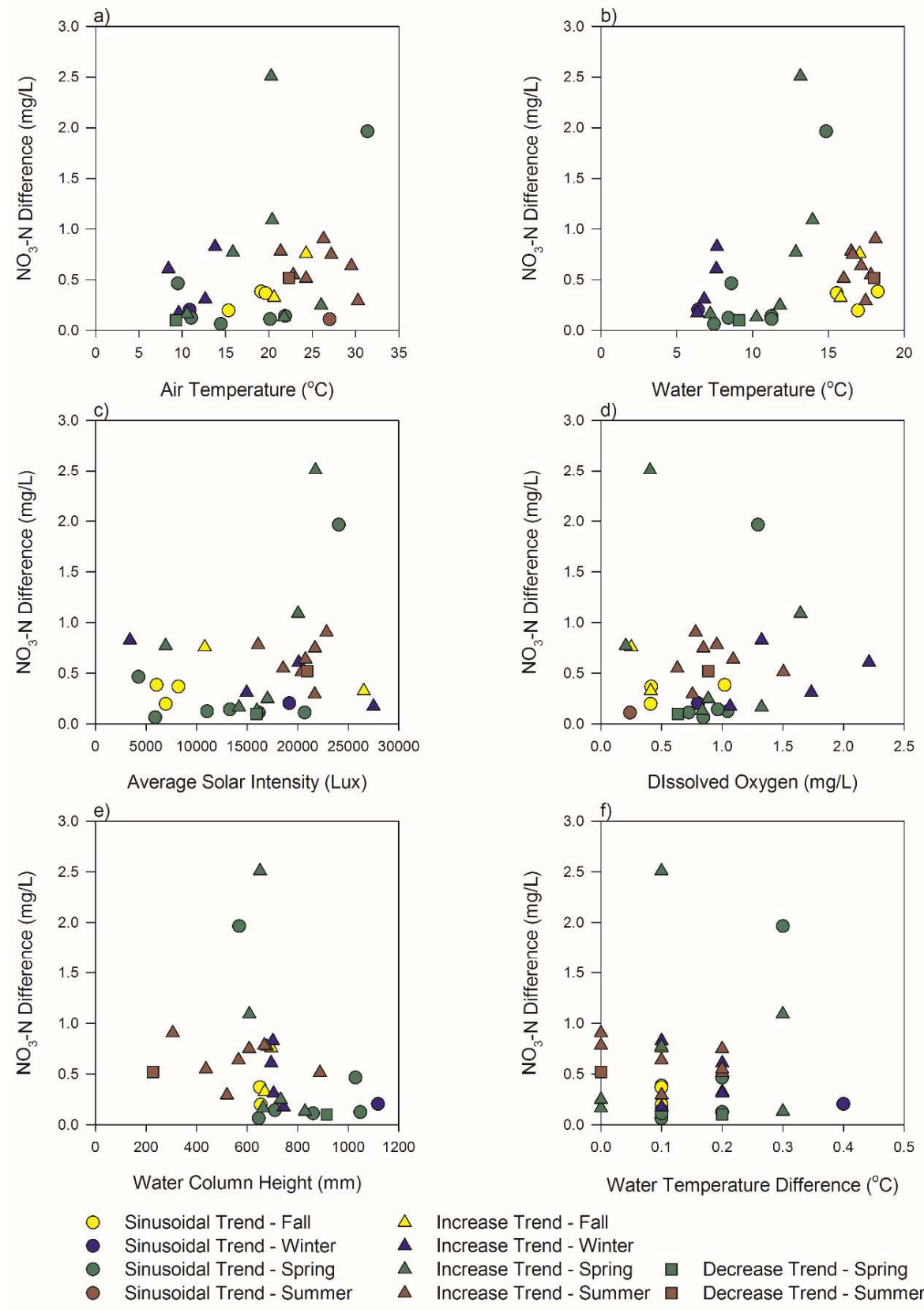

Sinusoidal Trend - Fall

Sinusoidal Trend - Spring

- Sinusoidal Trend - Summer

$\triangle$ Increase Trend - Fall

A Increase Trend - Winter

$\Delta$ Increase Trend-Spring $\square \quad$ Decrease Trend-Spring

Increase Trend-Summer $\square$ Decrease Trend-Summer

Figure 15. Environmental factor correlations for sinusoidal, increase, and decrease trends by season. Difference between 24-hour maximum and minimum on $\mathrm{Y}$ axis A) daily air temperature B) daily water temperature, range: $1.4-31.4^{\circ} \mathrm{C} \mathrm{C}$ ) daily average solar intensity D) daily dissolved oxygen E) water column height F) 24-hour water temperature difference. 


\section{Environmental Factors}

Environmental factor data were analyzed by grouping sinusoidal trend, increase trend, decrease trend, and all data. Groundwater temperature changes by an average of $0.14^{\circ} \mathrm{C}$ over $24-$ hours and follows air temperature seasonally increasing in summer and decreasing in winter (Figure 5) (Table 5). DO remains below the 4.5mg/L threshold identified by Gómez et al. (2002) throughout the entire study (Table 5). Water column height peaks at $>1,000 \mathrm{~mm}$ in January but then decreases to 600 to $700 \mathrm{~mm}$ from February to April (Figure 5). Another peak in water column height occurs in April from which it decreases with minor variation until August (Figure 5). Solar intensity in August 2016 is $\sim 15,000$ lux but decreases to $<5,000$ lux in February 2017

(Figure 5). From February 2017 solar intensity increases steadily to 20,000 to 25,000 lux in June 2017 (Figure 5). Seasonal means for all environmental factors are presented in Table 5. Overall, no significant correlations exist among the environmental factors and the $\mathrm{NO}_{3}^{-}-\mathrm{N}$ concentration difference. Water temperature does not display a significant correlation with $\mathrm{NO}_{3}{ }^{-}-\mathrm{N}$ concentration difference (Pearson correlation $\mathrm{r}=0.31, \mathrm{p}=0.08$ ) (Figure 15). Water temperature change over 24-hours does not display a significant correlation with $\mathrm{NO}_{3}^{-}-\mathrm{N}$ concentration difference (Pearson correlation $\mathrm{r}=-0.25, \mathrm{p}=0.20$ ) (Figure 15). When all data is analyzed together, other environmental factors including air temperature, average solar value, water column height, and dissolved oxygen do not display a correlation with $\mathrm{NO}_{3}^{-}-\mathrm{N}$ concentration difference (Figure 15). When data are grouped as diurnal sinusoidal and increase/decrease trends, environmental factors including water temperature, air temperature, average solar value, water column height, and dissolved oxygen do not display a significant correlation with $\mathrm{NO}_{3}{ }^{-}-\mathrm{N}$ concentration difference (Figure 15). 
Table 5 .

Seasonal Means \pm Standard Deviation for Environmental Factors

\begin{tabular}{lllllll}
\hline Season & Water & Dissolved & Groundwater & Air & Average & Temperature \\
& Column & Oxygen & Temperature & Temperature & Solar Value & Difference \\
& Height & $(\mathrm{mg} / \mathrm{L})$ & $\left({ }^{\circ} \mathrm{C}\right)$ & $\left({ }^{\circ} \mathrm{C}\right)$ & $(\mathrm{lux}) *$ & over 24- \\
& $(\mathrm{mm})$ & & & & & hours $\left({ }^{\circ} \mathrm{C}\right)$ \\
\hline Spring & $764 \pm 157$ & $0.90 \pm 0.40$ & $12.27 \pm 5.35$ & $17.88 \pm 6.82$ & $14,707 \pm 6,276$ & $0.15 \pm 0.11$ \\
Summer & $527 \pm 209$ & $0.85 \pm 0.34$ & $18.02 \pm 1.58$ & $25.68 \pm 3.17$ & $19,907 \pm 2,440$ & $0.10 \pm 0.09$ \\
Fall & $667 \pm 20$ & $0.50 \pm 0.30$ & $16.73 \pm 1.08$ & $19.79 \pm 3.21$ & $11,710 \pm 8,481$ & $0.12 \pm 0.04$ \\
Winter & $786 \pm 164$ & $1.67 \pm 0.77$ & $6.96 \pm 0.76$ & $9.45 \pm 4.40$ & $14,606 \pm 9,905$ & $0.18 \pm 0.12$ \\
All & $695 \pm 190$ & $0.97 \pm 0.58$ & $13.36 \pm 5.33$ & $18.77 \pm 7.38$ & $15,652 \pm 6,976$ & $0.14 \pm 0.10$ \\
Seasons & & & & & &
\end{tabular}

Note. $*$ average solar value $=\frac{\sum \text { hourly solar intensity }}{24 \text { hours }} ; \operatorname{lux}=1 \mathrm{umen} / \mathrm{m}^{2}$ 


\section{CHAPTER IV: DISCUSSION}

Over the duration of the study, statistically significant variation in $\mathrm{NO}_{3}{ }^{-}-\mathrm{N}$ concentration is observed on the seasonal scale (Figure 11) (Table 4). Seasonally, both spring and summer have significantly greater $\mu_{\text {daily }\left[\mathrm{NO}^{-}-\mathrm{N}\right]}$ than fall, while spring, summer, and winter combinations are similar (Figure 11) (Table 4). Therefore, the hypothesis that there will be no significant

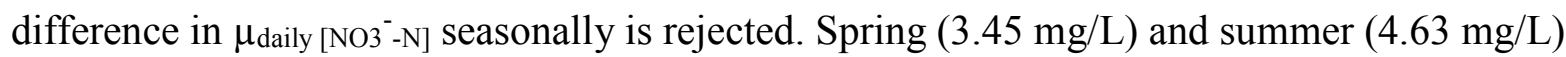
display high $\mu_{\text {daily }\left[\mathrm{NO}^{-}-\mathrm{N}\right]}$ and can be described as enriched compared to fall $(2.18 \mathrm{mg} / \mathrm{L})$, while fall can be described as depleted. The enriched spring and summer $\mu_{\text {daily }\left[\mathrm{NO}^{-}{ }^{-} \mathrm{N}\right]}$ coincides with routine fertilizer application for this area in March and May (Lamb, 2004). Although additional fertilizer is typically applied post-harvest, the use of N-Serve with a fall fertilizer application would result in the delay of $\mathrm{NO}_{3}{ }^{-}$generation, accounting for the depleted $\mu_{\text {daily }\left[\mathrm{NO}^{-}{ }^{-} \mathrm{N}\right]}$ observed in fall and enriched $\mu_{\text {daily }\left[\mathrm{NO}^{-}-\mathrm{N}\right]}$ in winter. N-Serve delays $\mathrm{NO}_{3}{ }^{-}$generation by slowing bacterial nitrification of anhydrous ammonia, the form of nitrogen fertilizer used in Central Illinois (Lamb, 2004).

Within each season, the 24 -hour $\mu_{\max }\left[\mathrm{NO}^{-}-\mathrm{N}\right]$ is significantly greater than the 24 -hour $\mu_{\min }$ ${ }^{\left[\mathrm{NO}^{-}-\mathrm{N}\right]}$ (Figure 12) (Table 2). Therefore, the hypothesis that there will be no significant

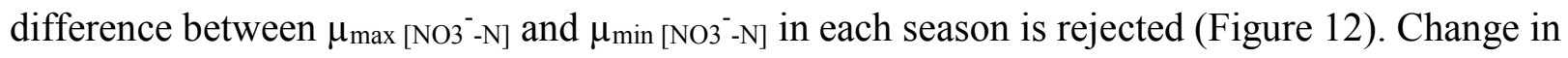
$\mathrm{NO}_{3}{ }^{-}-\mathrm{N}$ concentration over a 24-hour period is the result of both physical and biological processes such as vegetation uptake, nitrification, dilution, and $\mathrm{NO}_{3}{ }^{-}$transport. The source of diurnal change in $\mathrm{NO}_{3}{ }^{-}-\mathrm{N}$ concentration can be identified through examination of the high resolution 24-hour time-series $\mathrm{NO}_{3}{ }^{-}-\mathrm{N}$ concentration data. Specific processes manifest as a specific trend in groundwater $\mathrm{NO}_{3}{ }^{-}-\mathrm{N}$ concentration over time. Time-series data followed three trends of hourly change over 24-hours: increase, decrease, and sinusoidal (Figure 6). 
Summer and winter diurnal changes in $\mathrm{NO}_{3}^{-}-\mathrm{N}$ concentration are primarily caused by three processes of $\mathrm{NO}_{3}{ }^{-} \mathrm{N}$ concentration increase, as the increase trend produced by these three processes comprises $>50 \%$ of sampling days in these seasons (Figure 14). The three processes of $\mathrm{NO}_{3}{ }^{-}-\mathrm{N}$ concentration increase include: input of $\mathrm{NO}_{3}{ }^{-}$to the system by transport from outside the saturated buffer, concentration of solute by evapotranspiration, and nitrification.

Input of $\mathrm{NO}_{3}{ }^{-}$to the system by transport from outside the saturated buffer is possible by advection-dispersion. Moore and Peterson, 2007 found $\mathrm{NO}_{3}{ }^{-}$transport by advection-dispersion in glacial till, the material of this study site, to be related to fertilizer application and unrelated to precipitation events. The upgradient agricultural land-use area would serve as a $\mathrm{NO}_{3}{ }^{-}$source with potential for transport downgradient to the saturated buffer. This explanation fits observed 24hour scale $\mathrm{NO}_{3}^{-}-\mathrm{N}^{-}$and $\mathrm{Cl}^{-}$data. Data show $\mathrm{NO}_{3}{ }^{-} \mathrm{N}^{-}$and $\mathrm{Cl}^{-}$concentration increase together but do not increase in parallel (Figure 6). Downgradient transport of $\mathrm{NO}_{3}{ }^{-}$from fertilizer application could include $\mathrm{Cl}^{-}$, because $\mathrm{Cl}^{-}$is a degradation product of $\mathrm{N}$-serve, a nitrogen stabilizer, known to be applied with fertilizer in this area (Lamb, 2004). Degradation of $\mathrm{N}-\mathrm{Serve}$ to $\mathrm{Cl}^{-}$provides a source of $\mathrm{Cl}^{-}$that is transported alongside $\mathrm{NO}_{3}{ }^{-}$in similar but non-parallel amounts, accounting for the observed $\mathrm{NO}_{3}-\mathrm{N}$ and $\mathrm{Cl}^{-}$concentration changes.

Evapotranspiration (ET) may play a role by concentrating solute in the shallow subsurface. McIsaac et al. (2010) estimated the May-November 2005-2008 average evapotranspiration total for switchgrass plots in Central Illinois to be 291-308 mm based on soil moisture measurements. Water table fluctuations related to ET have been observed on the seasonal and diurnal scales (Satchithanantham et al., 2017) and even used to estimate vegetation water demands (Nachabe et al., 2005, Loheide Ii, 2008). It is conceivable that switchgrass ET concentrated $\mathrm{NO}_{3}{ }^{-}$in the shallow aquifer by removing water from the system on the seasonal 
scale. Across the field site, diurnal changes in head correspond with long term increases or decreases and do not exhibit cyclic diurnal fluctuation (unreported data). Evaporation removes water from the system directly, by vaporizing water from the land surface and soil. Transpiration is a process where vegetation transmits water from root tissue to leaves and the atmosphere. $\mathrm{NO}_{3}{ }^{-}$ uptake by vegetation operates independently of transpiration (Hopmans \& Bristow, 2002), meaning $\mathrm{NO}_{3}{ }^{-}$concentration by $\mathrm{ET}$ is possible if the rate of $\mathrm{ET}$ is greater than the rate $\mathrm{of} \mathrm{NO}_{3}{ }^{-}$ uptake. Water column height data supports ET as a mechanism, as water column height generally dropped over periods of $\mathrm{NO}_{3}^{-}-\mathrm{N}$ concentration increase. The substantial drop in water column height observed from June 2017 to August 2017 (Figure 5) indicates a lack of rain that would drive vegetation to extract water from the aquifer. The 24-hour time-series increase trend $\mathrm{NO}_{3}{ }^{-}-\mathrm{N}$ and $\mathrm{Cl}^{-}$data taken in conjunction with water column height data support ET as a contributor to $\mathrm{NO}_{3}{ }^{-}-\mathrm{N}$ and $\mathrm{Cl}^{-}$concentration increases, as $\mathrm{NO}_{3}{ }^{-}-\mathrm{N}$ and $\mathrm{Cl}^{-}$concentration increases are loosely coupled (Figure 6). ET cannot be the only cause of $\mathrm{NO}_{3}^{-}-\mathrm{N}$ concentration increases, because $\mathrm{NO}_{3}^{-}-\mathrm{N}$ concentration increases faster than $\mathrm{Cl}^{-}$concentration.

Nitrification is another mechanism that may contribute to the observed increase in $\mathrm{NO}_{3}^{-}$N. Nitrification produces $\mathrm{NO}_{3}{ }^{-}$independent of $\mathrm{Cl}^{-}$and can account for the minor divergence in $\mathrm{NO}_{3}{ }^{-}-\mathrm{N}$ and $\mathrm{Cl}^{-}$concentration, where $\mathrm{NO}_{3}{ }^{-}$increases faster than $\mathrm{Cl}^{-}$(Figure 6). Nitrification is a nitrogen transformation process where ammonium $\left(\mathrm{NH}_{4}{ }^{+}\right)$is converted to $\mathrm{NO}_{3}{ }^{-}$via aerobic microbial metabolism (Hefting et al., 2004). Nitrification is not possible in anoxic conditions, leaving ammonium to accumulate until nitrification can occur (Hefting et al., 2004). Ammonium could have accumulated in the saturated zone pore space until the water table dropped enough for pore space to become aerated and support the conversion of $\mathrm{NH}_{4}{ }^{+}$to $\mathrm{NO}_{3}{ }^{-}$by nitrification in the unsaturated zone. No data was collected in the unsaturated zone, but saturated zone average 
DO concentration remained below the $1.0 \mathrm{mg} / \mathrm{L}$ threshold, below which nitrification remains arrested allowing $\mathrm{NH}_{4}{ }^{+}$accumulation, identified by Garrido et al. (1997) in spring, summer, and fall (Table 5). Further supporting this speculation, water column height decreased over periods where $\mathrm{NO}_{3}^{-}-\mathrm{N}$ concentration increased (Figure 5). Similar to this study, Hefting et al. (2004) found nitrification to increase as water table level dropped. $\mathrm{NO}_{3}{ }^{-}$produced by nitrification in the unsaturated zone could be transported to the saturated zone by percolating soil water. Soil water is known to be a conduit by which solutes can be transported through unsaturated flow (Nielsen et al., 1986).

A multi-mechanism process of $\mathrm{NO}_{3}{ }^{-}-\mathrm{N}$ concentration increase is the best supported explanation, given the similar but slightly faster increase in $\mathrm{NO}_{3}{ }^{-}-\mathrm{N}$ compared to $\mathrm{Cl}^{-}$. The multi mechanism process includes ET driven concentration of solute and water table drop, nitrification stimulated by water table drop and aeration, and transported $\mathrm{NO}_{3}{ }^{-}$from upgradient agricultural land use. The primary mechanism, or mechanism producing the greatest change, likely varies through the year as environmental conditions change favoring one over another. For example, increases during the winter are more likely driven by $\mathrm{NO}_{3}{ }^{-}$transport than ET or nitrification. Evaporation is decreased during winter months in Central Illinois, and transpiration is limited as vegetation goes dormant. Data averaged over 35 years in Central Illinois, obtained from Angel (2017), displays total pan evaporation for October to be $<50 \%$ of July. Although a precise range for optimal nitrification is disputed, several studies agree that bacterial nitrification rates in soil decreases with temperature and steeply declines below $10^{\circ} \mathrm{C}$ (Frederick, 1956, Saad \& Conrad, 1993, Sabey et al., 1956).

The decrease trend was observed in spring and summer, but did not occur often and is not characteristic of any season. The two decrease trends observed display a parallel decrease in 
$\mathrm{NO}_{3}{ }^{-}-\mathrm{N}$ and $\mathrm{Cl}^{-}$, indicative of dilution (Figure 6). Further providing evidence of dilution, precipitation events of $\sim 12 \mathrm{~mm}$ occurred $4-5$ days before the sampling periods that generated the 24-hour decreasing $\mathrm{NO}_{3}{ }^{-}-\mathrm{N}$ concentration trends (Angel, 2017). Precipitation takes days to infiltrate and may contribute to dilution of solute in the aquifer several days later.

Spring and fall changes in $\mathrm{NO}_{3}{ }^{-}-\mathrm{N}$ concentration on the 24-hour scale is primarily caused by vegetation uptake, as the sinusoidal trend produced by vegetation uptake comprises $\geq 50 \%$ of trends observed in these seasons. Vegetation uptake produces the sinusoidal trend by extraction of $\mathrm{NO}_{3}{ }^{-}$from the surficial aquifer during the photoperiod and a lack of vegetation extraction during the dark period. Delhon et al. (1996) observed a similar sinusoidal trend in $\mathrm{NO}_{3}{ }^{-}$uptake rate that displayed a relationship to photoperiod in soybean (Figure 2). Spring and fall environmental conditions support vegetation growth, as air and groundwater temperature data remain well above the $10^{\circ} \mathrm{C}$ threshold for plant growth (Mitchell et al., 1997) (Figure 5) (Table 5). Well-developed root systems of vegetation like switchgrass, the dominant species on the study site, are known to have a great capacity for $\mathrm{NO}_{3}{ }^{-}$uptake (Schimel, 1986), capable of recovering $66 \%$ of applied nitrogen (Bransby et al., 1998). Switchgrass is not known to be a substantial nitrifier, and recent studies have found nitrogen fertilization to increase biomass yield (Lemus et al., 2008, Guretzky et al., 2011). An increase in biomass yield from fertilization confirms the responsiveness of switchgrass to $\mathrm{NO}_{3}{ }^{-}$inputs. This study site was not fertilized and external $\mathrm{NO}_{3}{ }^{-}$inputs are limited to $\mathrm{NO}_{3}{ }^{-}$import from upgradient fields.

Time of maximum and minimum $\mathrm{NO}_{3}-\mathrm{N}$ concentration further indicates the process responsible for the sinusoidal trend is vegetation uptake. Time of maximum and minimum $\mathrm{NO}_{3}-$ $\mathrm{N}$ concentration varies by season for all data combined (Figure 7, Figure 8). However, sinusoidal trend days displayed a pronounced pattern of minimum $\mathrm{NO}_{3}{ }^{-} \mathrm{N}$ concentration at the end of the 
photoperiod and maximum $\mathrm{NO}_{3}{ }^{-}-\mathrm{N}$ concentration near the beginning (Figure 9, 10). During the summer, when days are longer, the time of minimum shifted to later in the day (Figure 10). Therefore, the hypothesis that there will be no difference in the time-of-day when the maximum and minimum $\mathrm{NO}_{3}{ }^{-}-\mathrm{N}$ concentration occurs for all seasons is rejected. Although the duration of the photoperiod differs between spring and summer, the observed relationship between photoperiod and $\mathrm{NO}_{3}{ }^{-}-\mathrm{N}$ concentration is the same (Figure 9, Figure 10). This is consistent with the findings of Delhon et al. (1996) that $\mathrm{NO}_{3}{ }^{-}$uptake in soybean coincided with photoperiod (Figure 2). Delhon et al. (1996) and Pearson and Steer (1977) reasoned that photoperiod controlled energy availability in plant vascular tissue through photosynthesis, and that $\mathrm{NO}_{3}{ }^{-}$ uptake is limited in dark conditions.

Relevant environmental factors such as water column height, groundwater temperature, air temperature, and solar intensity did not display a significant relationship with the magnitude of difference in $\mathrm{NO}_{3}{ }^{-}-\mathrm{N}$ concentration when grouped by trend or combined data (Figure 15). This is surprising, as an increase in vegetation uptake was expected with greater solar intensity and warmer temperatures. The lack of a strong relationship between environmental factors and vegetation uptake indicates that vegetation uptake is unaffected by changes beyond a threshold for photosynthesis, or that competing processes mask relationships that may exist. Samples taken during this study measured net $\mathrm{NO}_{3}{ }^{-}-\mathrm{N}$ concentration, meaning measured $\mathrm{NO}_{3}^{-}-\mathrm{N}$ concentration is the product of combined processes such as vegetation uptake, ET, nitrification, dilution, leaching, and denitrification. A process or group of related processes can only be identified by net $\mathrm{NO}_{3}{ }^{-}-\mathrm{N}$ concentration trends when sufficiently isolated from background.

An alternate process with the potential to produce a sinusoidal trend is microbial denitrification. If microbial denitrification rate changed within a 24-hour period, that change 
could produce a sinusoidal trend. Denitrification rate is controlled by temperature, dissolved oxygen, and dissolved organic carbon. If any of these factors varied on the 24-hour scale, then a change in denitrification rate would be expected. However, temperature and dissolved oxygen data do not support microbial denitrification as the mechanism for the sinusoidal trend.

Groundwater temperature varied by an average of $0.14 \pm$ the standard deviation of $0.01{ }^{\circ} \mathrm{C}$ over a 24-hour period for all seasons, and dissolved oxygen remained well below the $4.5 \mathrm{mg} / \mathrm{L}$ threshold for denitrification for all seasons (Table 5). Additionally, 24-hour water temperature difference displays no correlation with $\mathrm{NO}_{3}^{-}-\mathrm{N}$ concentration difference for days with sinusoidal trend or comprehensive data (Figure 15). Dissolved organic carbon samples were not collected in this study and is a topic for future research.

A higher frequency of sinusoidal trends was expected in summer, as the potential for photosynthesis is high during summer. However, competing processes overwhelmed the vegetation uptake signal. The vegetation uptake signal appears and disappears throughout the study period and is only observed once in summer. The presence or absence of a vegetation uptake signal requires the magnitude of hourly background variation to be lower than that of vegetation uptake. This observation is confirmed by other riparian zone studies which found $\mathrm{NO}_{3}{ }^{-}$processing mechanisms to operate independently or simultaneously depending on environmental conditions (Sabater et al., 2003, Haycock \& Pinay, 1993, Simmons et al., 1992). Winter displaying a sinusoidal trend once during the season was also surprising (Figure 14). However, this is explained by the unusually warm $>10^{\circ} \mathrm{C}$ average air temperature for the day, which would have allowed for vegetation uptake (Figure 5). Overall, winter $\mathrm{NO}_{3}{ }^{-}$concentrations are likely controlled by $\mathrm{NO}_{3}{ }^{-}$transport from upgradient sources. 
A statistically significant difference in $\mu_{\text {difference }\left[\mathrm{NO}^{-}-\mathrm{N}\right]}$ was expected among seasons, as some seasons are more heavily influenced by one process than another. This is evident in the frequency of each trend throughout the year, and the underlying mechanisms responsible for the trend i.e. vegetation uptake, ET, leaching, nitrification, and dilution. However, no statistically significant differences in $\mu_{\text {difference }\left[\mathrm{NO}^{-}{ }^{-} \mathrm{N}\right]}$ were found between any season combinations (Figure 15) (Table 3). Therefore, the hypothesis that there will be no significant difference between $\mu_{\text {difference }\left[\mathrm{NO}^{-}{ }^{-} \mathrm{N}\right]}$ among the four seasons is accepted. This means the magnitude of difference in $\mathrm{NO}_{3}{ }^{-}$concentration that occurred over 24 -hours due to vegetation uptake, nitrification, dilution, $\mathrm{NO}_{3}{ }^{-}$transport, and ET is similar. This may be due to a dampening effect from competing processes within one day or averaged over a season. Additionally, a lack of significant differences in $\mu_{\text {difference }\left[\mathrm{NO}^{-}-\mathrm{N}\right]}$ across seasons that have a significantly different $\mu_{\text {daily }\left[\mathrm{NO}^{-}{ }^{-} \mathrm{N}\right]}$

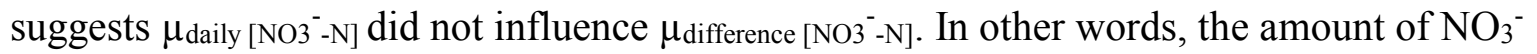
available did not affect the magnitude of 24-hour change observed in this study (Figure 16). Ultimately, this study has demonstrated that variation in $\mathrm{NO}_{3}{ }^{-}$concentration exists on both the seasonal and diurnal scale, multiple processes produce variation i.e. vegetation uptake, ET, nitrification, and $\mathrm{NO}_{3}{ }^{-}$transport, and that variation over 24-hours is consistent across processes. 


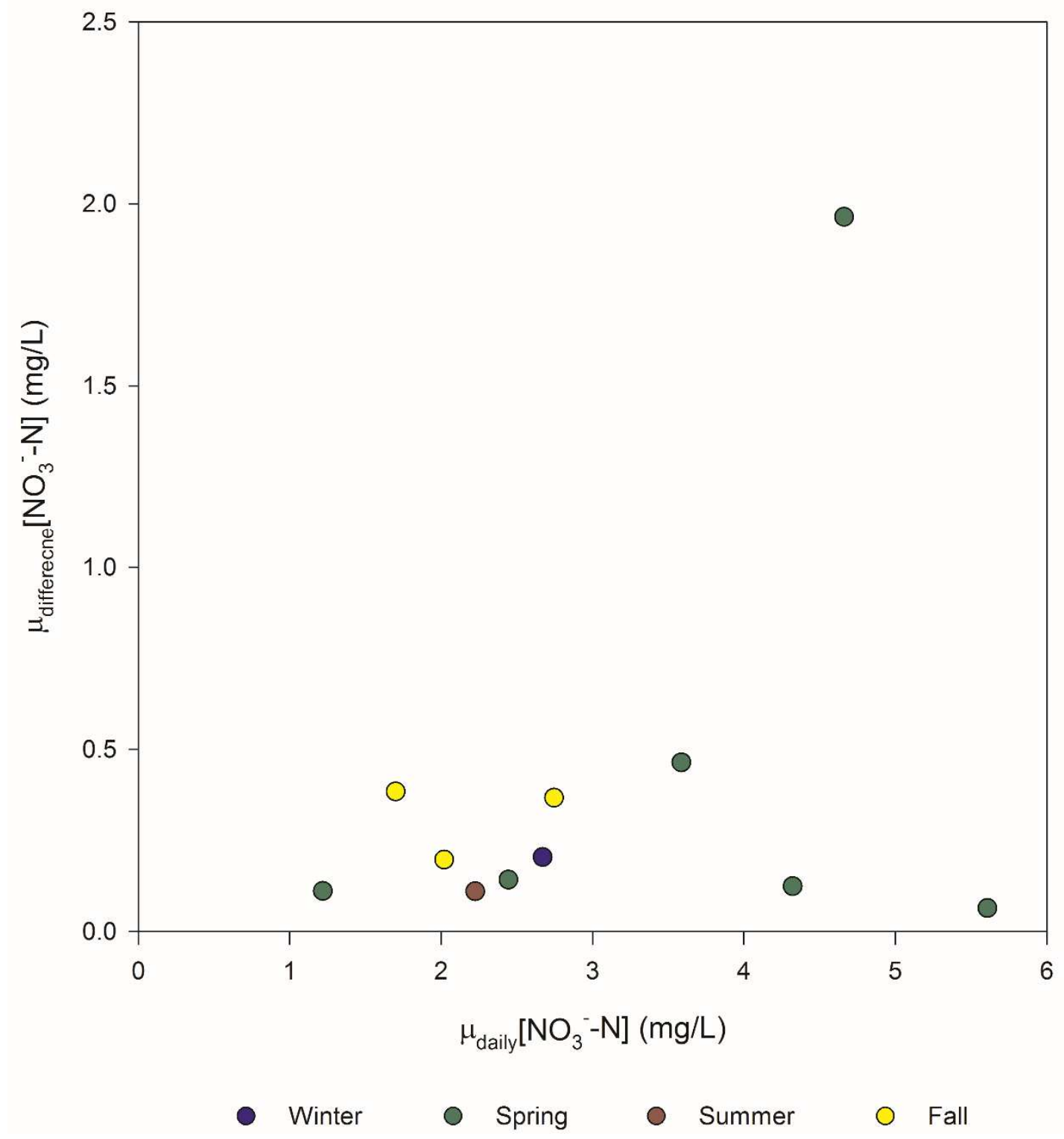

Figure 16. $\mu_{\text {daily }}\left[\mathrm{NO}_{3}{ }^{-}-\mathrm{N}\right]$ concentrations versus $\mu_{\text {differnece }}\left[\mathrm{NO}_{3}{ }^{-}-\mathrm{N}\right]$ for sinusoidal pattern. Despite a range of $5.4 \mathrm{mg} / \mathrm{L}$ in $\mu_{\text {daily }}\left[\mathrm{NO}_{3}{ }^{-}-\mathrm{N}\right]$, the majority of $\mu_{\text {differnece }}\left[\mathrm{NO}_{3}{ }^{-}-\mathrm{N}\right]$ exhibits minimal variation, a range of $0.4 \mathrm{mg} / \mathrm{L}$. 


\section{CHAPTER V: CONCLUSION}

Seasonally, both spring and summer average significantly greater daily $\mathrm{NO}_{3}{ }^{-}-\mathrm{N}$ concentrations than fall (Figure 11). Therefore, the hypothesis that there will be no significant difference in $\mu_{\text {daily }\left[\mathrm{NO}^{-}{ }^{-} \mathrm{N}\right]}$ seasonally is rejected. Within each season, average daily maximum $\mathrm{NO}_{3}{ }^{-}-\mathrm{N}$ concentration is significantly greater than average daily minimum (Figure 12).

Therefore, the hypothesis that there will be no significant difference between the $\mu_{\max }\left[\mathrm{NO}^{-}{ }^{-} \mathrm{N}\right]$ and $\mu_{\min \left[\mathrm{NO}^{-}-\mathrm{N}\right]} \mathrm{NO}_{3}{ }^{-}-\mathrm{N}$ concentration in each season is rejected (Figure 12). Time of maximum and minimum $\mathrm{NO}_{3}{ }^{-}-\mathrm{N}$ concentration varies by season (Figure 7, Figure 8). Therefore, the hypothesis that there will be no difference in the time-of-day when the maximum and minimum $\mathrm{NO}_{3}{ }^{-}-\mathrm{N}$ concentration occurs for all seasons is rejected. No statistically significant differences in $\mu_{\text {difference }}$ $\left[\mathrm{NO}^{-}{ }^{-} \mathrm{N}\right]$ Were found between any season combinations (Figure 13). Therefore, the hypothesis that there will be no significant difference between $\mu_{\text {difference }\left[\mathrm{NO}^{-}-\mathrm{N}\right]}$ among the four seasons is accepted.

The most notable observations in this study are the 24-hour time series vegetation uptake and multi-process increase signals. Time of maximum and minimum $\mathrm{NO}_{3}{ }^{-}-\mathrm{N}$ concentration data indicate vegetation uptake generates the sinusoidal trend. Time of maximum and minimum $\mathrm{NO}_{3}{ }^{-}$ -N concentration occurs when it would be expected for a photosynthetically controlled process. Maximum $\mathrm{NO}_{3}^{-}-\mathrm{N}$ concentration occurs during the dark period, while minimum $\mathrm{NO}_{3}{ }^{-}-\mathrm{N}$ concentration occurs at the end of the photoperiod (Figure 6, Figure 9, Figure 10). Vegetation uptake is observed under conditions where vegetation growth is possible and sufficiently isolated from competing processes by environmental conditions. The alternate explanation for the sinusoidal trend, denitrification, is not supported by these data. If denitrification were the process responsible for the time of maximum and time of minimum $\mathrm{NO}_{3}{ }^{-}-\mathrm{N}$ concentration, then the 
denitrification rate would need to change and would have to be driven by water temperature changes. No relationship exists between 24-hour water temperature difference and $\mathrm{NO}_{3}{ }^{-}-\mathrm{N}$ concentration difference (Figure 15). Additionally, these data indicate multiple processes are responsible for the increase trend. Anoxic conditions in the saturated zone coupled with water column height drops from ET provide ideal conditions for conversion of accumulated $\mathrm{NH}_{4}{ }^{+}$to $\mathrm{NO}_{3}{ }^{-}$in the unsaturated zone. $\mathrm{NO}_{3}{ }^{-}$produced by nitrification in the unsaturated zone was then transported to the saturated zone by unsaturated flow. $\mathrm{NO}_{3}{ }^{-}$transport from the upgradiant agricultural land use are best accounts for increases during the winter.

The results of this study may influence the way we understand saturated buffers. The role of vegetation $\mathrm{NO}_{3}{ }^{-}$uptake in saturated buffers is disputed, but these results provide evidence for a measurable contribution of $\mathrm{NO}_{3}{ }^{-}$removal by vegetation. Seasons that have a significantly different $\mu_{\text {daily }\left[\mathrm{NO}^{-}{ }^{-} \mathrm{N}\right]}$ do not have a significantly different $\mu_{\text {difference }\left[\mathrm{NO}^{-}{ }^{-} \mathrm{N}\right] \text {. This means the }}$ amount of $\mathrm{NO}_{3}{ }^{-}$available does not influence the magnitude of change over 24-hours. Future research could focus on quantification of total nitrogen captured by vegetation, $\mathrm{NO}_{3}{ }^{-}$flux in the unsaturated zone, and stable isotope methods for $\mathrm{NO}_{3}{ }^{-}$source and fate. This study focused on $\mathrm{NO}_{3}{ }^{-}-\mathrm{N}$ in the saturated zone, but other forms of nitrogen such as ammonium and nitrite in the unsaturated zone may be of interest. 


\section{REFERENCES}

Angel, J. (2017). Weather Observations for Champaign-Urbana. Illinois State Water Survey.

Beach, V. (2008). The impact of streambed sediment size on hyporheic temperature profiles in a low gradient third-order agricultural stream. Illinois State University, Normal.

Bedford, B.L., Bouldin, D.R. \& Beliveau, B.D. (1991). Net Oxygen and Carbon-Dioxide Balances in Solutions Bathing Roots of Wetland Plants. Journal of Ecology, 79, 943-959.

Bot, J.L. \& Kirkby, E. (1992). Diurnal uptake of nitrate and potassium during the vegetative growth of tomato plants. Journal of Plant Nutrition, 15, 247-264.

Bransby, D.I., Mclaughlin, S.B. \& Parrish, D.J. (1998). A review of carbon and nitrogen balances in switchgrass grown for energy. Biomass and Bioenergy, 14, 379-384.

Changnon, S.A., Angel, J.R., Kunkel, K.E. \& Lehmann, C.M.B. (2004). Climate atlas of Illinois. Illinois State Water Survey.

David, M.B. \& Gentry, L.E. (2000). Anthropogenic Inputs of Nitrogen and Phosphorus and Riverine Export for Illinois, USA. Journal of Environmental Quality, 29, 494-508.

David, M.B., Gentry, L.E., Kovacic, D.A. \& Smith, K.M. (1997). Nitrogen Balance in and Export from an Agricultural Watershed. Journal of Environmental Quality, 26, 10381048.

Delhon, P., Gojon, A., Tillard, P. \& Passama, L. (1996). Diurnal regulation of NO- 3 uptake in soybean plants IV. Dependence on current photosynthesis and sugar availability to the roots. Journal of Experimental Botany, 47, 893-900.

Fausey, N.R., Brown, L.C., Belcher, H.W. \& Kanwar, R.S. (1995). Drainage and water quality in Great Lakes and cornbelt states. Journal of Irrigation and Drainage Engineering, 121, 283-288. 
Frederick, L.R. (1956). The Formation of Nitrate from Ammonium Nitrogen in Soils: I. Effect of Temperature1. Soil Science Society of America Journal, 20, 496-500.

Garrido, J.M., Van Benthum, W.a.J., Van Loosdrecht, M.C.M. \& Heijnen, J.J. (1997). Influence of dissolved oxygen concentration on nitrite accumulation in a biofilm airlift suspension reactor. Biotechnology and Bioengineering, 53, 168-178.

Gilliam, J. (1994). Riparian wetlands and water quality. Journal of Environmental Quality, 23, 896-900.

Gómez, M., Hontoria, E. \& González-López, J. (2002). Effect of dissolved oxygen concentration on nitrate removal from groundwater using a denitrifying submerged filter. Journal of Hazardous Materials, 90, 267-278.

Groffman, P.M., Gold, A.J. \& Simmons, R.C. (1992). Nitrate dynamics in riparian forests: microbial studies. Journal of Environmental Quality, 21, 666-671.

Guretzky, J.A., Biermacher, J.T., Cook, B.J., Kering, M.K. \& Mosali, J. (2011). Switchgrass for forage and bioenergy: harvest and nitrogen rate effects on biomass yields and nutrient composition. Plant and Soil, 339, 69-81.

Haycock, N. \& Pinay, G. (1993). Groundwater nitrate dynamics in grass and poplar vegetated riparian buffer strips during the winter. Journal of Environmental Quality, 22, 273-278.

Hefting, M., Clément, J.C., Dowrick, D., Cosandey, A.C., Bernal, S., Cimpian, C., Tatur, A., Burt, T.P. \& Pinay, G. (2004). Water table elevation controls on soil nitrogen cycling in riparian wetlands along a European climatic gradient. Biogeochemistry, 67, 113-134.

Hill, A.R. (1996). Nitrate removal in stream riparian zones. Journal of Environmental Quality, $25,743-755$. 
Hill, A.R., Devito, K.J., Campagnolo, S. \& Sanmugadas, K. (2000). Subsurface denitrification in a forest riparianzone: interactions between hydrology and supplies ofnitrate and organic carbon. Biogeochemistry, 51, 193-223.

Hopmans, J.W. \& Bristow, K.L. (2002). Current Capabilities and Future Needs of Root Water and Nutrient Uptake Modeling. Advances in Agronomy (ed D.L. Sparks), pp. 103-183. Academic Press.

Hutchins, M.G. (2012). What impact might mitigation of diffuse nitrate pollution have on river water quality in a rural catchment? Journal of environmental management, 109, 19-26.

Jacks, G., Joelsson, A. \& Fleischer, S. (1994). Nitrogen retention in forest wetlands. Ambio, 358362.

Jordan, T.E., Correll, D.L. \& Weller, D.E. (1993). Nutrient Interception by a Riparian Forest Receiving Inputs from Adjacent Cropland. Journal of Environmental Quality, 22, 467473.

Keeney, D.R. \& Hatfield, J.L. (2001). The nitrogen cycle: Historical perspective, and current and potential future concerns. Nitrogen in the environment: Sources, problems, and solutions (eds R. Follett \& J.L. Hatfield), pp. 3-16. Elsevier, Amsterdam.

Kuusemets, V., Mander, Ü., Lõhmus, K. \& Ivask, M. (2001). Nitrogen and phosphorus variation in shallow groundwater and assimilation in plants in complex riparian buffer zones. Water Science and Technology, 44, 615-622.

Lamb, D. (2004). Vadose and Shallow Saturated Nitrate Transport at Lake Bloomington, Illinois. MS, Illinois State University, Normal, IL. 
Lemus, R., Charles Brummer, E., Lee Burras, C., Moore, K.J., Barker, M.F. \& Molstad, N.E. (2008). Effects of nitrogen fertilization on biomass yield and quality in large fields of established switchgrass in southern Iowa, USA. Biomass and Bioenergy, 32, 1187-1194.

Loheide Ii, S.P. (2008). A method for estimating subdaily evapotranspiration of shallow groundwater using diurnal water table fluctuations. Ecohydrology, 1, 59-66.

Lowrance, R. (1992). Groundwater Nitrate and Denitrification in a Coastal Plain Riparian Forest. Journal of Environmental Quality, 21, 401-405.

Mcisaac, G.F., David, M.B. \& Mitchell, C.A. (2010). Miscanthus and Switchgrass Production in Central Illinois: Impacts on Hydrology and Inorganic Nitrogen Leaching All rights reserved. No part of this periodical may be reproduced or transmitted in any form or by any means, electronic or mechanical, including photocopying, recording, or any information storage and retrieval system, without permission in writing from the publisher. Journal of Environmental Quality, 39, 1790-1799.

Mengel, K. (1996). Turnover of organic nitrogen in soils and its availability to crops. Plant and Soil, 181, 83-93.

Miller, A.J. \& Cramer, M.D. (2005). Root nitrogen acquisition and assimilation. Root Physiology: from Gene to Function (eds H. Lambers \& T.D. Colmer), pp. 1-36. Springer Netherlands, Dordrecht.

Mitchell, R.B., Moore, K.J., Moser, L.E., Fritz, J.O. \& Redfearn, D.D. (1997). Predicting Developmental Morphology in Switchgrass and Big Bluestem. Agronomy Journal, 89, $827-832$. 
Nachabe, M., Shah, N., Ross, M. \& Vomacka, J. (2005). Evapotranspiration of Two Vegetation Covers in a Shallow Water Table Environment. Soil Science Society of America Journal, $69,492-499$.

Nielsen, D.R., Th. Van Genuchten, M. \& Biggar, J.W. (1986). Water flow and solute transport processes in the unsaturated zone. Water Resources Research, 22, 89S-108S.

North, R.L., Winter, J.G. \& Dillon, P.J. (2013). Nutrient indicators of agricultural impacts in the tributaries of a large lake. Inland Waters, 3, 221-234.

Oberle, S.L. \& Keeney, D.R. (1990). Factors Influencing Corn Fertilizer N Requirements in the Northern U.S. Corn Belt. Journal of Production Agriculture, 3, 527-534.

Pearson, C.J. \& Steer, B.T. (1977). Daily changes in nitrate uptake and metabolism in Capsicum annuum. Planta, 137, 107-112.

Pinay, G., Roques, L. \& Fabre, A. (1993). Spatial and Temporal Patterns of Denitrification in a Riparian Forest. Journal of Applied Ecology, 30, 581-591.

Rabalais, N.N., Turner, R.E. \& Wiseman, W.J. (2002). Gulf of Mexico Hypoxia, a.k.a. "The Dead Zone". Annual Review of Ecology and Systematics, 33, 235-263.

Ramsey, F.L. \& Schafer, D.W. (2002). The Statistical Sleuth: A Course in Methods of Data Analysis. Duxbury/Thomson Learning, Pacific Grove, CA.

Ryther, J.H. \& Dunstan, W.M. (1971). Nitrogen, Phosphorus, and Eutrophication in the Coastal Marine Environment. Science, 171, 1008-1013.

Saad, O.a.L.O. \& Conrad, R. (1993). Temperature dependence of nitrification, denitrification, and turnover of nitric oxide in different soils. Biology and Fertility of Soils, 15, 21-27.

Sabater, S., Butturini, A., Clement, J.-C., Burt, T., Dowrick, D., Hefting, M., Matre, V., Pinay, G., Postolache, C., Rzepecki, M. \& Sabater, F. (2003). Nitrogen Removal by Riparian 
Buffers along a European Climatic Gradient: Patterns and Factors of Variation. Ecosystems, 6, 0020-0030.

Sabey, B.R., Bartholomew, W.V., Shaw, R. \& Pesek, J. (1956). Influence of Temperature on Nitrification in Soils1. Soil Science Society of America Journal, 20, 357-360.

Satchithanantham, S., Wilson, H.F. \& Glenn, A.J. (2017). Contrasting patterns of groundwater evapotranspiration in grass and tree dominated riparian zones of a temperate agricultural catchment. Journal of Hydrology, 549, 654-666.

Scaife, A. \& Schloemer, S. (1994). The Diurnal Pattern of Nitrate Uptake and Reduction by Spinach (Spinacia oleracea L.). Annals of Botany, 73, 337-343.

Schimel, D.S. (1986). Carbon and nitrogen turnover in adjacent grassland and cropland ecosystems. Biogeochemistry, 2, 345-357.

Scott, D., Harvey, J., Alexander, R. \& Schwarz, G. (2007). Dominance of organic nitrogen from headwater streams to large rivers across the conterminous United States. Global Biogeochemical Cycles, 21, n/a-n/a.

Simmons, R.C., Gold, A.J. \& Groffman, P.M. (1992). Nitrate Dynamics in Riparian Forests: Groundwater Studies. Journal of Environmental Quality, 21, 659-665.

Stanford, G., Dzienia, S. \& Vander Pol, R.A. (1975). Effect of Temperature on Denitrification Rate in Soils1. Soil Science Society of America Journal, 39, 867-870.

Weedman, N.R., Malone, D.H. \& Shields, W.E. (2014). Surficial Geologic Map of the Normal West 7.5 Minute Quadrangle, McLean County, Illinois. (ed Illinois State Geological Survey). Illinois State Geological Survey, http://isgs.illinois.edu/maps/isgsquads/surficial-geology/student-map/normal-west. 
Weller, D.E., Correll, D. \& Jordan, T.E. (1994). Denitrification in riparian forests receiving agricultural discharges. Global wetlands: old world and new, 117-131.

Wickham, S.S., Johnson, W.H. \& Glass, H.D. (1988). Regional geology of the Tiskilwa Till Member, Wedron Formation, northeastern Illinois. Circular no. 543.

Zumft, W.G. (1997). Cell biology and molecular basis of denitrification. Microbiology and Molecular Biology Reviews, 61, 533-616. 
APPENDIX A: COLLECTED DATA BY DAY 
Table A-1.

Daily Average $\mathrm{NO}_{3}^{-}-\mathrm{N}$ Data for Each Collection Event

\begin{tabular}{|c|c|c|c|c|c|c|}
\hline Date & Season & $\begin{array}{c}\text { Maximum } \\
\mathrm{NO}_{3}^{-}-\mathrm{N} \\
(\mathrm{mg} / \mathrm{L})\end{array}$ & $\begin{array}{c}\text { Minimum } \\
\mathrm{NO}_{3}^{-}-\mathrm{N} \\
(\mathrm{mg} / \mathrm{L}) \\
\end{array}$ & $\begin{array}{c}\text { Difference } \\
\mathrm{NO}_{3}^{-}-\mathrm{N} \\
(\mathrm{mg} / \mathrm{L})\end{array}$ & $\begin{array}{c}\text { Time of } \\
\text { Maximum }\end{array}$ & $\begin{array}{c}\text { Time of } \\
\text { Minimum }\end{array}$ \\
\hline $8 / 24 / 2016$ & Summer & 2.26 & 2.15 & 0.11 & 5:00 AM & $8: 00$ PM \\
\hline $10 / 5 / 2016$ & Fall & 1.92 & 1.54 & 0.38 & 2:00 AM & $11: 00 \mathrm{AM}$ \\
\hline $10 / 16 / 2016$ & Fall & 1.96 & 1.20 & 0.76 & 4:00 PM & 1:00 PM \\
\hline $10 / 18 / 2016$ & Fall & 2.10 & 1.90 & 0.20 & 6:00 AM & 5:00 PM \\
\hline $10 / 28 / 2016$ & Fall & 2.79 & 2.46 & 0.33 & 2:00 PM & 3:00 PM \\
\hline $11 / 1 / 2016$ & Fall & 2.89 & 2.52 & 0.37 & $10: 00 \mathrm{AM}$ & 4:00 PM \\
\hline $1 / 20 / 2017$ & Winter & 2.75 & 2.55 & 0.20 & 1:00 AM & 1:00 PM \\
\hline $2 / 7 / 2017$ & Winter & 1.40 & 1.26 & 0.14 & 3:00 PM & 7:00 PM \\
\hline $2 / 16 / 2017$ & Winter & 2.31 & 2.13 & 0.17 & $6: 00 \mathrm{AM}$ & 12:00 PM \\
\hline $2 / 21 / 2017$ & Winter & 3.11 & 2.80 & 0.31 & 2:00 PM & 3:00 PM \\
\hline $2 / 28 / 2017$ & Winter & 4.97 & 4.15 & 0.83 & $11: 00 \mathrm{AM}$ & 12:00 PM \\
\hline $3 / 7 / 2017$ & Winter & 4.95 & 4.35 & 0.61 & 4:00 AM & 5:00 PM \\
\hline $3 / 20 / 2017$ & Spring & 5.94 & 5.77 & 0.16 & 5:00 AM & $11: 00 \mathrm{AM}$ \\
\hline $3 / 24 / 2017$ & Spring & 5.63 & 5.57 & 0.06 & 5:00 AM & 6:00 PM \\
\hline $4 / 1 / 2017$ & Spring & 4.38 & 4.25 & 0.12 & 10:00 PM & 12:00 PM \\
\hline $4 / 4 / 2017$ & Spring & 3.77 & 3.30 & 0.46 & 7:00 PM & 1:00 PM \\
\hline $4 / 11 / 2017$ & Spring & 2.54 & 2.45 & 0.10 & $10: 00 \mathrm{AM}$ & 1:00 AM \\
\hline $4 / 18 / 2017$ & Spring & 2.31 & 2.18 & 0.13 & 11:00 AM & $12: 00 \mathrm{AM}$ \\
\hline $4 / 25 / 2017$ & Spring & 2.47 & 2.33 & 0.14 & 4:00 AM & 4:00 PM \\
\hline $5 / 9 / 2017$ & Spring & 1.25 & 1.14 & 0.11 & $8: 00$ AM & 1:00 PM \\
\hline $5 / 15 / 2017$ & Spring & 2.07 & 1.82 & 0.25 & 1:00 PM & 3:00 PM \\
\hline $5 / 22 / 2017$ & Spring & 2.24 & 1.47 & 0.77 & 12:00 PM & 3:00 PM \\
\hline $5 / 29 / 2017$ & Spring & 3.98 & 1.48 & 2.51 & 2:00 PM & 5:00 PM \\
\hline $6 / 6 / 2017$ & Spring & 4.91 & 3.82 & 1.09 & 4:00 AM & 2:00 PM \\
\hline $6 / 13 / 2017$ & Spring & 5.17 & 3.20 & 1.96 & $12: 00 \mathrm{AM}$ & 5:00 PM \\
\hline $6 / 20 / 2017$ & Summer & 3.67 & 3.16 & 0.51 & 3:00 AM & 9:00 AM \\
\hline $6 / 27 / 2017$ & Summer & 3.33 & 2.55 & 0.78 & $11: 00 \mathrm{AM}$ & 12:00 PM \\
\hline $7 / 5 / 2017$ & Summer & 4.80 & 4.05 & 0.75 & $12: 00$ PM & 1:00 AM \\
\hline $7 / 12 / 2017$ & Summer & 5.63 & 4.99 & 0.64 & 2:00 PM & 3:00 PM \\
\hline $7 / 18 / 2017$ & Summer & 5.89 & 5.60 & 0.29 & $12: 00$ PM & 1:00 PM \\
\hline $7 / 24 / 2017$ & Summer & 6.30 & 5.75 & 0.55 & 8:00 AM & 9:00 AM \\
\hline $8 / 2 / 2017$ & Summer & 6.00 & 5.10 & 0.90 & $11: 00 \mathrm{AM}$ & 12:00 PM \\
\hline $8 / 8 / 2017$ & Summer & 5.43 & 4.90 & 0.52 & 11:00 AM & 8:00 AM \\
\hline
\end{tabular}

Note. Includes: date, season, daily maximum $\mathrm{NO}_{3}{ }^{-}-\mathrm{N}$, daily minimum $\mathrm{NO}_{3}{ }^{-} \mathrm{N}$, daily difference

$\mathrm{NO}_{3}{ }^{-}-\mathrm{N}$, daily time of maximum $\mathrm{NO}_{3}{ }^{-}-\mathrm{N}$, and daily time of minimum $\mathrm{NO}_{3}{ }^{-}-\mathrm{N}$. 
Table A-2.

Daily Average Environmental Data for Each Collection Event

\begin{tabular}{|c|c|c|c|c|c|c|}
\hline Date & Season & $\begin{array}{c}\text { Mean Air } \\
\text { Temperature } \\
\left({ }^{\circ} \mathrm{C}\right)\end{array}$ & $\begin{array}{c}\text { Mean Water } \\
\text { Temperature } \\
\left({ }^{\circ} \mathrm{C}\right)\end{array}$ & $\begin{array}{c}\text { Mean Solar } \\
\text { Intensity (lux) }\end{array}$ & $\begin{array}{l}\text { Mean Water } \\
\text { Column } \\
\text { Height (mm) }\end{array}$ & $\begin{array}{c}\text { Mean DO } \\
(\mathrm{mg} / \mathrm{L})\end{array}$ \\
\hline $8 / 24 / 2016$ & Summer & 27.02 & & 16159 & & 0.24 \\
\hline $10 / 5 / 2016$ & Fall & 19.11 & 18.25 & 6049 & & 1.02 \\
\hline $10 / 16 / 2016$ & Fall & 24.29 & 17.05 & 10801 & 695.00 & 0.25 \\
\hline $10 / 18 / 2016$ & Fall & 15.34 & 16.95 & 6957 & 654.00 & 0.41 \\
\hline $10 / 28 / 2016$ & Fall & 20.61 & 15.80 & 26541 & 670.00 & 0.41 \\
\hline $11 / 1 / 2016$ & Fall & 19.63 & 15.55 & 8203 & 651.00 & 0.42 \\
\hline $1 / 20 / 2017$ & Winter & 10.86 & 6.40 & 19175 & 1118.00 & 0.80 \\
\hline $2 / 7 / 2017$ & Winter & 1.41 & 6.25 & 2467 & 752.00 & 2.88 \\
\hline $2 / 16 / 2017$ & Winter & 9.59 & 6.35 & 27513 & 745.00 & 1.07 \\
\hline $2 / 21 / 2017$ & Winter & 12.66 & 6.80 & 14955 & 705.00 & 1.74 \\
\hline $2 / 28 / 2017$ & Winter & 13.79 & 7.65 & 3411 & 702.00 & 1.33 \\
\hline $3 / 7 / 2017$ & Winter & 8.41 & 7.60 & 20117 & 695.00 & 2.21 \\
\hline $3 / 20 / 2017$ & Spring & 10.56 & 7.20 & 14192 & 663.00 & 1.33 \\
\hline $3 / 24 / 2017$ & Spring & 14.46 & 7.45 & 5917 & 646.00 & 0.85 \\
\hline $4 / 1 / 2017$ & Spring & 11.04 & 8.40 & 11048 & 1048.00 & 1.05 \\
\hline $4 / 4 / 2017$ & Spring & 9.49 & 8.60 & 4263 & 1029.00 & \\
\hline $4 / 11 / 2017$ & Spring & 9.26 & 9.10 & 15932 & 915.00 & 0.64 \\
\hline $4 / 18 / 2017$ & Spring & 21.76 & 10.25 & 15984 & 829.00 & 0.84 \\
\hline $4 / 25 / 2017$ & Spring & 21.87 & 11.25 & 13311 & 710.00 & 0.97 \\
\hline $5 / 9 / 2017$ & Spring & 20.14 & 11.25 & 20695 & 861.00 & 0.73 \\
\hline $5 / 15 / 2017$ & Spring & 26.03 & 11.80 & 17018 & 733.00 & 0.89 \\
\hline $5 / 22 / 2017$ & Spring & 15.85 & 12.85 & 6943 & 678.00 & 0.21 \\
\hline $5 / 29 / 2017$ & Spring & 20.26 & 13.15 & 21772 & 651.00 & 0.41 \\
\hline $6 / 6 / 2017$ & Spring & 20.38 & 13.95 & 20042 & 609.00 & 1.65 \\
\hline $6 / 13 / 2017$ & Spring & 31.38 & 14.85 & 24075 & 569.00 & 1.30 \\
\hline $6 / 20 / 2017$ & Summer & 24.30 & 16.00 & 20387 & 888.00 & 1.51 \\
\hline $6 / 27 / 2017$ & Summer & 21.34 & 16.50 & 16081 & 668.00 & 0.96 \\
\hline $7 / 5 / 2017$ & Summer & 27.21 & 16.60 & 21718 & 608.00 & 0.85 \\
\hline $7 / 12 / 2017$ & Summer & 29.52 & 17.15 & 20766 & 566.00 & 1.09 \\
\hline $7 / 18 / 2017$ & Summer & 30.27 & 17.45 & 21683.09 & 520.00 & 0.76 \\
\hline $7 / 24 / 2017$ & Summer & 22.82 & 17.80 & 18571.42 & 437.00 & 0.63 \\
\hline $8 / 2 / 2017$ & Summer & 26.32 & 18.10 & 22857.71 & 306.00 & 0.78 \\
\hline $8 / 8 / 2017$ & Summer & 22.31 & 18.00 & 20940.83 & 227.00 & 0.89 \\
\hline
\end{tabular}

Note. Includes: date, season, mean air temperature, mean water temperature, mean solar

intensity, water column height, and dissolved oxygen. Parameters collected from inside the well 
(water temperature, water column height, and dissolved oxygen) were averaged from 2 measurements, one before sampling and one after. Before and after measurements were used for parameters collected from inside the sample well, as the act of sampling could influence the measurement. 
APPENDIX B: COLLECTED DATA BY HOUR 
Table B-1.

Hourly Data

\begin{tabular}{|c|c|c|c|c|c|c|c|}
\hline Date & Season & Time & $\begin{array}{l}\text { Order } \\
\text { in } \\
\text { Series }\end{array}$ & $\begin{array}{l}\mathrm{NO}_{3}{ }^{-}-\mathrm{N} \\
(\mathrm{mg} / \mathrm{L})\end{array}$ & $\begin{array}{c}\mathrm{Cl}^{-} \\
(\mathrm{mg} / \mathrm{L})\end{array}$ & $\begin{array}{c}\text { Air } \\
\text { Temperature } \\
\text { (Hourly) }\left({ }^{\circ} \mathrm{C}\right)\end{array}$ & $\begin{array}{l}\text { Solar Intensity } \\
\text { (Hourly) (lux) }\end{array}$ \\
\hline $8 / 24 / 2016$ & Summer & $12: 00$ AM & 5 & 2.23 & 7.46 & 23.39 & 0 \\
\hline $8 / 24 / 2016$ & Summer & 1:00 AM & 6 & 2.22 & 7.47 & 22.62 & 0 \\
\hline $8 / 24 / 2016$ & Summer & 2:00 AM & 7 & 2.24 & 7.48 & 19.66 & 0 \\
\hline $8 / 24 / 2016$ & Summer & 3:00 AM & 8 & 2.24 & 7.48 & 20.14 & 0 \\
\hline $8 / 24 / 2016$ & Summer & 4:00 AM & 9 & 2.25 & 7.49 & 19.85 & 0 \\
\hline $8 / 24 / 2016$ & Summer & 5:00 AM & 10 & 2.26 & 7.51 & 19.76 & 0 \\
\hline $8 / 24 / 2016$ & Summer & $6: 00 \mathrm{AM}$ & 11 & 2.24 & 7.72 & 19.47 & 11 \\
\hline $8 / 24 / 2016$ & Summer & 7:00 AM & 12 & 2.24 & 7.54 & 20.81 & 17222 \\
\hline $8 / 24 / 2016$ & Summer & $8: 00$ AM & 13 & 2.23 & 7.52 & 24.84 & 24800 \\
\hline $8 / 24 / 2016$ & Summer & $9: 00$ AM & 14 & 2.23 & 7.53 & 23.77 & 7578 \\
\hline $8 / 24 / 2016$ & Summer & 10:00 AM & 15 & 2.23 & 7.54 & 32.29 & 46845 \\
\hline $8 / 24 / 2016$ & Summer & $11: 00 \mathrm{AM}$ & 16 & 2.23 & 7.54 & 32.60 & 33067 \\
\hline $8 / 24 / 2016$ & Summer & 12:00 PM & 17 & 2.22 & 7.79 & 34.59 & 35823 \\
\hline $8 / 24 / 2016$ & Summer & 1:00 PM & 18 & 2.22 & 7.58 & 35.65 & 35823 \\
\hline $8 / 24 / 2016$ & Summer & 2:00 PM & 19 & 2.22 & 7.57 & 37.71 & 52356 \\
\hline $8 / 24 / 2016$ & Summer & 3:00 PM & 20 & 2.21 & 7.59 & 37.49 & 52356 \\
\hline $8 / 24 / 2016$ & Summer & 4:00 PM & 21 & 2.22 & 7.83 & 37.17 & 44089 \\
\hline $8 / 24 / 2016$ & Summer & 5:00 PM & 22 & 2.22 & 7.58 & 35.12 & 14467 \\
\hline $8 / 24 / 2016$ & Summer & 6:00 PM & 23 & 2.23 & 7.85 & 33.95 & 22045 \\
\hline $8 / 24 / 2016$ & Summer & 7:00 PM & 24 & 2.22 & 7.65 & 27.17 & 1324 \\
\hline $8 / 24 / 2016$ & Summer & 8:00 PM & 1 & 2.15 & 7.91 & 22.72 & 0 \\
\hline $8 / 24 / 2016$ & Summer & 9:00 PM & 2 & 2.21 & 7.53 & 23.00 & 0 \\
\hline $8 / 24 / 2016$ & Summer & 10:00 PM & 3 & 2.21 & 7.47 & 22.91 & 0 \\
\hline $8 / 24 / 2016$ & Summer & 11:00 PM & 4 & 2.23 & 7.46 & 21.76 & 0 \\
\hline $10 / 5 / 2016$ & Fall & $12: 00 \mathrm{AM}$ & 8 & 1.77 & 6.44 & 12.88 & 0 \\
\hline $10 / 5 / 2016$ & Fall & 1:00 AM & 9 & 1.83 & 6.76 & 16.81 & 0 \\
\hline $10 / 5 / 2016$ & Fall & $2: 00 \mathrm{AM}$ & 10 & 1.92 & 6.87 & 14.90 & 0 \\
\hline $10 / 5 / 2016$ & Fall & $3: 00$ AM & 11 & 1.79 & 6.47 & 14.90 & 0 \\
\hline
\end{tabular}

(Table Continues) 


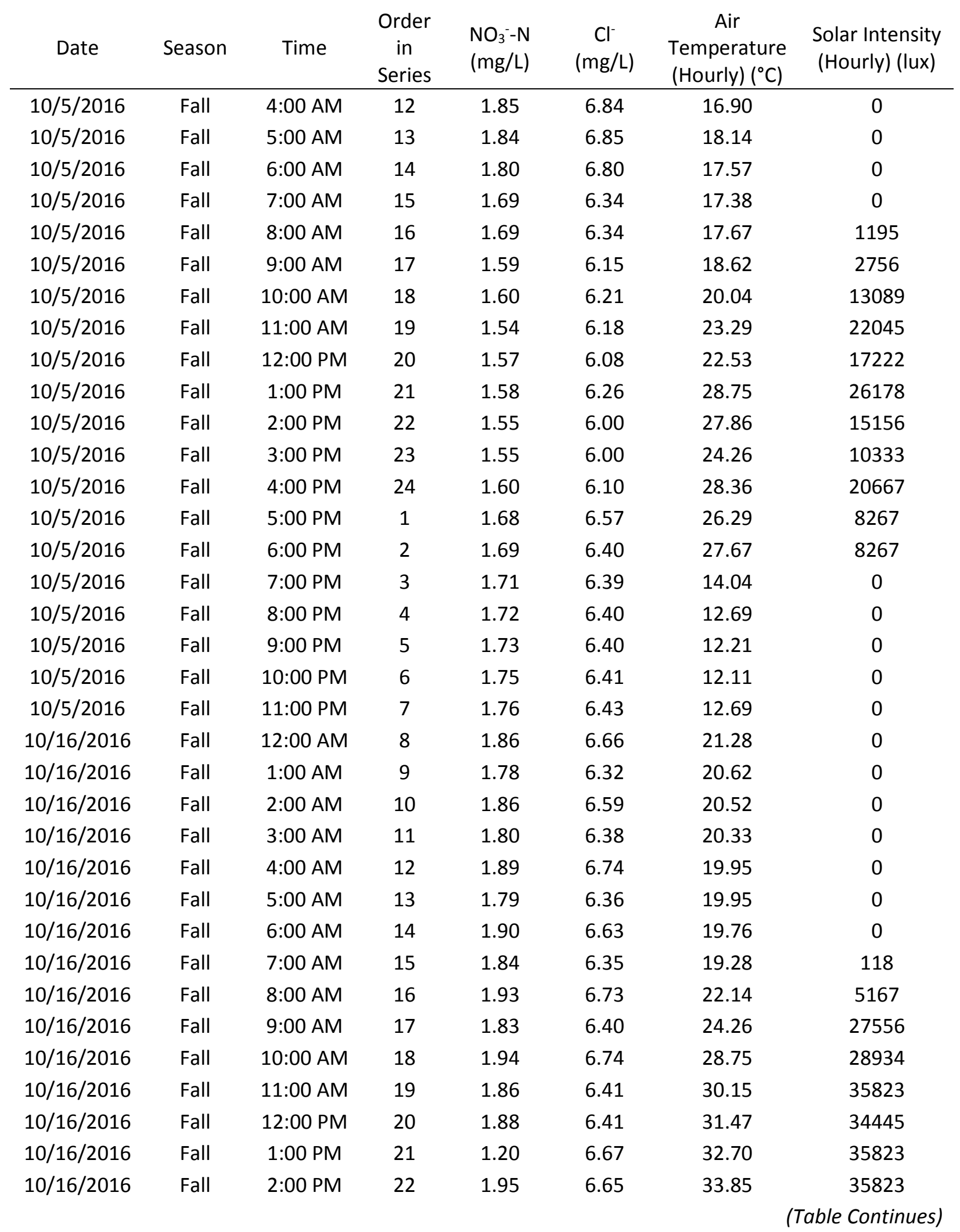




\begin{tabular}{|c|c|c|c|c|c|c|c|}
\hline Date & Season & Time & $\begin{array}{l}\text { Order } \\
\text { in } \\
\text { Series }\end{array}$ & $\begin{array}{l}\mathrm{NO}_{3}{ }^{-}-\mathrm{N} \\
(\mathrm{mg} / \mathrm{L})\end{array}$ & $\begin{array}{c}\mathrm{Cl}^{-} \\
(\mathrm{mg} / \mathrm{L})\end{array}$ & $\begin{array}{c}\text { Air } \\
\text { Temperature } \\
\text { (Hourly) }\left({ }^{\circ} \mathrm{C}\right)\end{array}$ & $\begin{array}{l}\text { Solar Intensity } \\
\text { (Hourly) (lux) }\end{array}$ \\
\hline $10 / 16 / 2016$ & Fall & 3:00 PM & 23 & 1.95 & 6.71 & 33.74 & 34445 \\
\hline $10 / 16 / 2016$ & Fall & 4:00 PM & 24 & 1.96 & 6.74 & 31.27 & 12400 \\
\hline $10 / 16 / 2016$ & Fall & 5:00 PM & 1 & 1.48 & 6.59 & 24.93 & 6200 \\
\hline $10 / 16 / 2016$ & Fall & 6:00 PM & 2 & 1.64 & 6.56 & 22.53 & 2497 \\
\hline $10 / 16 / 2016$ & Fall & 7:00 PM & 3 & 1.63 & 6.26 & 20.33 & 0 \\
\hline $10 / 16 / 2016$ & Fall & 8:00 PM & 4 & 1.68 & 6.28 & 20.42 & 0 \\
\hline $10 / 16 / 2016$ & Fall & 9:00 PM & 5 & 1.80 & 6.58 & 21.57 & 0 \\
\hline $10 / 16 / 2016$ & Fall & 10:00 PM & 6 & 1.82 & 6.61 & 21.66 & 0 \\
\hline $10 / 16 / 2016$ & Fall & 11:00 PM & 7 & 1.82 & 6.62 & 21.38 & 0 \\
\hline $10 / 18 / 2016$ & Fall & $12: 00 \mathrm{AM}$ & 9 & 2.03 & 6.53 & 8.28 & 0 \\
\hline $10 / 18 / 2016$ & Fall & 1:00 AM & 10 & 2.06 & 6.62 & 7.48 & 0 \\
\hline $10 / 18 / 2016$ & Fall & 2:00 AM & 11 & 2.06 & 6.67 & 6.98 & 0 \\
\hline $10 / 18 / 2016$ & Fall & $3: 00$ AM & 12 & 2.00 & 6.52 & 6.47 & 0 \\
\hline $10 / 18 / 2016$ & Fall & 4:00 AM & 13 & 2.02 & 6.32 & 6.98 & 0 \\
\hline $10 / 18 / 2016$ & Fall & 5:00 AM & 14 & 2.01 & 6.54 & 6.78 & 0 \\
\hline $10 / 18 / 2016$ & Fall & 6:00 AM & 15 & 2.10 & 6.69 & 5.24 & 0 \\
\hline $10 / 18 / 2016$ & Fall & 7:00 AM & 16 & 2.03 & 6.48 & 5.14 & 344 \\
\hline $10 / 18 / 2016$ & Fall & $8: 00$ AM & 17 & 2.09 & 6.64 & 11.24 & 5511 \\
\hline $10 / 18 / 2016$ & Fall & 9:00 AM & 18 & 2.00 & 6.39 & 20.23 & 22045 \\
\hline $10 / 18 / 2016$ & Fall & $10: 00 \mathrm{AM}$ & 19 & 2.05 & 6.35 & 24.74 & 27556 \\
\hline $10 / 18 / 2016$ & Fall & $11: 00 \mathrm{AM}$ & 20 & 2.05 & 6.39 & 26.20 & 34445 \\
\hline $10 / 18 / 2016$ & Fall & 12:00 PM & 21 & 2.06 & 6.50 & 25.22 & 28934 \\
\hline $10 / 18 / 2016$ & Fall & 1:00 PM & 22 & 2.05 & 6.51 & 21.38 & 13089 \\
\hline $10 / 18 / 2016$ & Fall & 2:00 PM & 23 & 2.05 & 6.58 & 20.04 & 9300 \\
\hline $10 / 18 / 2016$ & Fall & 3:00 PM & 24 & 2.06 & 6.59 & 20.33 & 6200 \\
\hline $10 / 18 / 2016$ & Fall & 4:00 PM & 1 & 1.91 & 6.33 & 26.78 & 11711 \\
\hline $10 / 18 / 2016$ & Fall & 5:00 PM & 2 & 1.90 & 6.29 & 24.06 & 6200 \\
\hline $10 / 18 / 2016$ & Fall & 6:00 PM & 3 & 2.02 & 6.59 & 21.66 & 1636 \\
\hline $10 / 18 / 2016$ & Fall & 7:00 PM & 4 & 2.02 & 6.57 & 17.95 & 0 \\
\hline $10 / 18 / 2016$ & Fall & 8:00 PM & 5 & 1.98 & 6.48 & 16.81 & 0 \\
\hline $10 / 18 / 2016$ & Fall & 9:00 PM & 6 & 2.00 & 6.39 & 15.57 & 0 \\
\hline $10 / 18 / 2016$ & Fall & 10:00 PM & 7 & 1.96 & 6.42 & 13.65 & 0 \\
\hline $10 / 18 / 2016$ & Fall & 11:00 PM & 8 & 1.99 & 6.58 & 8.98 & 0 \\
\hline $10 / 28 / 2016$ & Fall & $12: 00 \mathrm{AM}$ & 10 & 2.74 & 6.91 & 17.57 & 0 \\
\hline $10 / 28 / 2016$ & Fall & 1:00 AM & 11 & 2.62 & 6.82 & 17.67 & 0 \\
\hline
\end{tabular}

(Table Continues) 


\begin{tabular}{|c|c|c|c|c|c|c|c|}
\hline Date & Season & Time & $\begin{array}{l}\text { Order } \\
\text { in } \\
\text { Series }\end{array}$ & $\begin{array}{l}\mathrm{NO}_{3}^{-}-\mathrm{N} \\
(\mathrm{mg} / \mathrm{L})\end{array}$ & $\begin{array}{c}\mathrm{Cl}^{-} \\
(\mathrm{mg} / \mathrm{L})\end{array}$ & $\begin{array}{c}\text { Air } \\
\text { Temperature } \\
\text { (Hourly) }\left({ }^{\circ} \mathrm{C}\right)\end{array}$ & $\begin{array}{l}\text { Solar Intensity } \\
\text { (Hourly) (lux) }\end{array}$ \\
\hline $10 / 28 / 2016$ & Fall & 2:00 AM & 12 & 2.72 & 6.93 & 17.67 & 0 \\
\hline $10 / 28 / 2016$ & Fall & 3:00 AM & 13 & 2.62 & 6.86 & 17.76 & 0 \\
\hline $10 / 28 / 2016$ & Fall & 4:00 AM & 14 & 2.73 & 6.94 & 17.28 & 0 \\
\hline $10 / 28 / 2016$ & Fall & 5:00 AM & 15 & 2.64 & 6.62 & 17.38 & 0 \\
\hline $10 / 28 / 2016$ & Fall & 6:00 AM & 16 & 2.65 & 6.64 & 17.48 & 0 \\
\hline $10 / 28 / 2016$ & Fall & 7:00 AM & 17 & 2.76 & 6.90 & 16.81 & 11 \\
\hline $10 / 28 / 2016$ & Fall & $8: 00$ AM & 18 & 2.67 & 6.65 & 18.90 & 23422 \\
\hline $10 / 28 / 2016$ & Fall & 9:00 AM & 19 & 2.78 & 6.98 & 20.62 & 31689 \\
\hline $10 / 28 / 2016$ & Fall & 10:00 AM & 20 & 2.75 & 6.84 & 22.53 & 37200 \\
\hline $10 / 28 / 2016$ & Fall & 11:00 AM & 21 & 2.68 & 6.66 & 28.06 & 99201 \\
\hline $10 / 28 / 2016$ & Fall & 12:00 PM & 22 & 2.69 & 6.88 & 28.16 & 132268 \\
\hline $10 / 28 / 2016$ & Fall & 1:00 PM & 23 & 2.78 & 6.97 & 31.57 & 126756 \\
\hline $10 / 28 / 2016$ & Fall & 2:00 PM & 24 & 2.79 & 6.98 & 30.76 & 85423 \\
\hline $10 / 28 / 2016$ & Fall & 3:00 PM & 1 & 2.46 & 6.96 & 25.13 & 57867 \\
\hline $10 / 28 / 2016$ & Fall & 4:00 PM & 2 & 2.54 & 6.84 & 23.97 & 34445 \\
\hline $10 / 28 / 2016$ & Fall & 5:00 PM & 3 & 2.50 & 6.62 & 20.62 & 8611 \\
\hline $10 / 28 / 2016$ & Fall & 6:00 PM & 4 & 2.59 & 6.78 & 17.95 & 97 \\
\hline $10 / 28 / 2016$ & Fall & 7:00 PM & 5 & 2.53 & 6.51 & 17.19 & 0 \\
\hline $10 / 28 / 2016$ & Fall & 8:00 PM & 6 & 2.58 & 6.53 & 17.38 & 0 \\
\hline $10 / 28 / 2016$ & Fall & 9:00 PM & 7 & 2.66 & 6.80 & 17.38 & 0 \\
\hline $10 / 28 / 2016$ & Fall & 10:00 PM & 8 & 2.69 & 6.79 & 17.48 & 0 \\
\hline $10 / 28 / 2016$ & Fall & 11:00 PM & 9 & 2.59 & 6.57 & 17.38 & 0 \\
\hline $11 / 1 / 2016$ & Fall & $12: 00 \mathrm{AM}$ & 8 & 2.77 & 6.81 & 18.14 & 0 \\
\hline $11 / 1 / 2016$ & Fall & 1:00 AM & 9 & 2.75 & 6.67 & 18.05 & 0 \\
\hline $11 / 1 / 2016$ & Fall & 2:00 AM & 10 & 2.83 & 6.95 & 17.67 & 0 \\
\hline $11 / 1 / 2016$ & Fall & $3: 00$ AM & 11 & 2.79 & 6.66 & 17.57 & 0 \\
\hline $11 / 1 / 2016$ & Fall & 4:00 AM & 12 & 2.75 & 6.65 & 17.19 & 0 \\
\hline $11 / 1 / 2016$ & Fall & 5:00 AM & 13 & 2.76 & 6.67 & 16.90 & 0 \\
\hline $11 / 1 / 2016$ & Fall & 6:00 AM & 14 & 2.85 & 6.81 & 16.62 & 0 \\
\hline $11 / 1 / 2016$ & Fall & 7:00 AM & 15 & 2.77 & 6.65 & 16.62 & 0 \\
\hline $11 / 1 / 2016$ & Fall & $8: 00$ AM & 16 & 2.77 & 6.67 & 16.71 & 3100 \\
\hline $11 / 1 / 2016$ & Fall & 9:00 AM & 17 & 2.79 & 6.75 & 20.42 & 26178 \\
\hline $11 / 1 / 2016$ & Fall & 10:00 AM & 18 & 2.89 & 6.95 & 25.51 & 17911 \\
\hline $11 / 1 / 2016$ & Fall & $11: 00 \mathrm{AM}$ & 19 & 2.76 & 6.86 & 22.14 & 4306 \\
\hline $11 / 1 / 2016$ & Fall & $12: 00$ PM & 20 & 2.81 & 6.75 & 17.00 & 6545 \\
\hline
\end{tabular}




\begin{tabular}{|c|c|c|c|c|c|c|c|}
\hline Date & Season & Time & $\begin{array}{l}\text { Order } \\
\text { in } \\
\text { Series }\end{array}$ & $\begin{array}{l}\mathrm{NO}_{3}^{-}-\mathrm{N} \\
(\mathrm{mg} / \mathrm{L})\end{array}$ & $\begin{array}{c}\mathrm{Cl}^{-} \\
(\mathrm{mg} / \mathrm{L})\end{array}$ & $\begin{array}{c}\text { Air } \\
\text { Temperature } \\
\text { (Hourly) }\left({ }^{\circ} \mathrm{C}\right)\end{array}$ & $\begin{array}{c}\text { Solar Intensity } \\
\text { (Hourly) (lux) }\end{array}$ \\
\hline $11 / 1 / 2016$ & Fall & 1:00 PM & 21 & 2.60 & 6.69 & 22.33 & 33067 \\
\hline $11 / 1 / 2016$ & Fall & 2:00 PM & 22 & 2.62 & 6.70 & 28.66 & 82667 \\
\hline $11 / 1 / 2016$ & Fall & 3:00 PM & 23 & 2.61 & 6.80 & 22.81 & 7578 \\
\hline $11 / 1 / 2016$ & Fall & 4:00 PM & 24 & 2.52 & 6.76 & 22.24 & 2325 \\
\hline $11 / 1 / 2016$ & Fall & 5:00 PM & 1 & 2.66 & 6.80 & 26.39 & 13089 \\
\hline $11 / 1 / 2016$ & Fall & 6:00 PM & 2 & 2.75 & 7.02 & 18.43 & 118 \\
\hline $11 / 1 / 2016$ & Fall & 7:00 PM & 3 & 2.79 & 6.97 & 17.76 & 0 \\
\hline $11 / 1 / 2016$ & Fall & 8:00 PM & 4 & 2.71 & 6.66 & 17.28 & 0 \\
\hline $11 / 1 / 2016$ & Fall & 9:00 PM & 5 & 2.80 & 6.93 & 16.05 & 0 \\
\hline $11 / 1 / 2016$ & Fall & 10:00 PM & 6 & 2.73 & 6.67 & 19.66 & 0 \\
\hline $11 / 1 / 2016$ & Fall & 11:00 PM & 7 & 2.82 & 6.93 & 18.90 & 0 \\
\hline $1 / 20 / 2017$ & Winter & $12: 00 \mathrm{AM}$ & 11 & 2.74 & 6.64 & 9.37 & 0 \\
\hline $1 / 20 / 2017$ & Winter & 1:00 AM & 12 & 2.75 & 6.72 & 9.77 & 0 \\
\hline $1 / 20 / 2017$ & Winter & 2:00 AM & 13 & 2.74 & 6.76 & 10.36 & 0 \\
\hline $1 / 20 / 2017$ & Winter & 3:00 AM & 14 & 2.63 & 6.52 & 9.57 & 0 \\
\hline $1 / 20 / 2017$ & Winter & 4:00 AM & 15 & 2.71 & 6.70 & 9.18 & 0 \\
\hline $1 / 20 / 2017$ & Winter & 5:00 AM & 16 & 2.62 & 6.50 & 8.58 & 0 \\
\hline $1 / 20 / 2017$ & Winter & $6: 00 \mathrm{AM}$ & 17 & 2.60 & 6.55 & 8.58 & 0 \\
\hline $1 / 20 / 2017$ & Winter & 7:00 AM & 18 & 2.70 & 6.69 & 7.98 & 0 \\
\hline $1 / 20 / 2017$ & Winter & $8: 00 \mathrm{AM}$ & 19 & 2.68 & 6.70 & 8.28 & 151 \\
\hline $1 / 20 / 2017$ & Winter & 9:00 AM & 20 & 2.60 & 6.56 & 12.50 & 57867 \\
\hline $1 / 20 / 2017$ & Winter & 10:00 AM & 21 & 2.66 & 6.72 & 17.86 & 93690 \\
\hline $1 / 20 / 2017$ & Winter & 11:00 AM & 22 & 2.67 & 6.70 & 19.66 & 115734 \\
\hline $1 / 20 / 2017$ & Winter & $12: 00$ PM & 23 & 2.65 & 6.72 & 20.14 & 115734 \\
\hline $1 / 20 / 2017$ & Winter & 1:00 PM & 24 & 2.55 & 6.55 & 21.57 & 60623 \\
\hline $1 / 20 / 2017$ & Winter & 2:00 PM & 1 & 2.61 & 6.55 & 9.08 & 5511 \\
\hline $1 / 20 / 2017$ & Winter & 3:00 PM & 2 & 2.66 & 6.60 & 9.87 & 4478 \\
\hline $1 / 20 / 2017$ & Winter & 4:00 PM & 3 & 2.66 & 6.57 & 10.16 & 5339 \\
\hline $1 / 20 / 2017$ & Winter & 5:00 PM & 4 & 2.71 & 6.50 & 8.88 & 1055 \\
\hline $1 / 20 / 2017$ & Winter & 6:00 PM & 5 & 2.69 & 6.49 & 8.28 & 22 \\
\hline $1 / 20 / 2017$ & Winter & 7:00 PM & 6 & 2.70 & 6.48 & 8.08 & 0 \\
\hline $1 / 20 / 2017$ & Winter & 8:00 PM & 7 & 2.69 & 6.51 & 7.98 & 0 \\
\hline $1 / 20 / 2017$ & Winter & 9:00 PM & 8 & 2.69 & 6.50 & 7.68 & 0 \\
\hline $1 / 20 / 2017$ & Winter & 10:00 PM & 9 & 2.67 & 6.53 & 7.98 & 0 \\
\hline $1 / 20 / 2017$ & Winter & 11:00 PM & 10 & 2.74 & 6.67 & 9.18 & 0 \\
\hline
\end{tabular}

(Table Continues) 


\begin{tabular}{|c|c|c|c|c|c|c|c|}
\hline Date & Season & Time & $\begin{array}{l}\text { Order } \\
\text { in } \\
\text { Series }\end{array}$ & $\begin{array}{l}\mathrm{NO}_{3}{ }^{-}-\mathrm{N} \\
(\mathrm{mg} / \mathrm{L})\end{array}$ & $\begin{array}{c}\mathrm{Cl}^{-} \\
(\mathrm{mg} / \mathrm{L})\end{array}$ & $\begin{array}{c}\text { Air } \\
\text { Temperature } \\
\text { (Hourly) }\left({ }^{\circ} \mathrm{C}\right)\end{array}$ & $\begin{array}{c}\text { Solar Intensity } \\
\text { (Hourly) (lux) }\end{array}$ \\
\hline $2 / 7 / 2017$ & Winter & $12: 00 \mathrm{AM}$ & & & & -0.66 & 0 \\
\hline $2 / 7 / 2017$ & Winter & 1:00 AM & & & & -1.11 & 0 \\
\hline $2 / 7 / 2017$ & Winter & 2:00 AM & & & & -1.23 & 0 \\
\hline $2 / 7 / 2017$ & Winter & 3:00 AM & & & & -1.80 & 0 \\
\hline $2 / 7 / 2017$ & Winter & 4:00 AM & & & & -2.03 & 0 \\
\hline $2 / 7 / 2017$ & Winter & 5:00 AM & & & & -2.03 & 0 \\
\hline $2 / 7 / 2017$ & Winter & 6:00 AM & & & & -2.03 & 0 \\
\hline $2 / 7 / 2017$ & Winter & 7:00 AM & & & & -2.03 & 0 \\
\hline $2 / 7 / 2017$ & Winter & $8: 00$ AM & & & & -2.03 & 75 \\
\hline $2 / 7 / 2017$ & Winter & 9:00 AM & & & & -1.91 & 710 \\
\hline $2 / 7 / 2017$ & Winter & 10:00 AM & & & & -1.80 & 2239 \\
\hline $2 / 7 / 2017$ & Winter & 11:00 AM & & & & -1.23 & 4650 \\
\hline $2 / 7 / 2017$ & Winter & 12:00 PM & & & & 0.67 & 13778 \\
\hline $2 / 7 / 2017$ & Winter & 1:00 PM & & & & 0.78 & 22045 \\
\hline $2 / 7 / 2017$ & Winter & 2:00 PM & 1 & 1.31 & 5.43 & 10.26 & 3789 \\
\hline $2 / 7 / 2017$ & Winter & 3:00 PM & 2 & 1.40 & 5.63 & 10.16 & 7233 \\
\hline $2 / 7 / 2017$ & Winter & 4:00 PM & 3 & 1.38 & 5.52 & 9.37 & 3445 \\
\hline $2 / 7 / 2017$ & Winter & 5:00 PM & 4 & 1.34 & 5.27 & 7.98 & 1184 \\
\hline $2 / 7 / 2017$ & Winter & 6:00 PM & 5 & 1.32 & 5.16 & 6.37 & 65 \\
\hline $2 / 7 / 2017$ & Winter & 7:00 PM & 6 & 1.26 & 4.92 & 5.04 & 0 \\
\hline $2 / 7 / 2017$ & Winter & 8:00 PM & & & & 2.73 & 0 \\
\hline $2 / 7 / 2017$ & Winter & 9:00 PM & & & & 0.78 & 0 \\
\hline $2 / 7 / 2017$ & Winter & 10:00 PM & & & & -0.10 & 0 \\
\hline $2 / 7 / 2017$ & Winter & 11:00 PM & & & & -0.21 & 0 \\
\hline $2 / 16 / 2017$ & Winter & $12: 00$ AM & 13 & 2.27 & 5.93 & 6.17 & 0 \\
\hline $2 / 16 / 2017$ & Winter & 1:00 AM & 14 & 2.27 & 6.03 & 6.57 & 0 \\
\hline $2 / 16 / 2017$ & Winter & 2:00 AM & 15 & 2.27 & 6.01 & 6.27 & 0 \\
\hline $2 / 16 / 2017$ & Winter & 3:00 AM & 16 & 2.29 & 5.95 & 6.37 & 0 \\
\hline $2 / 16 / 2017$ & Winter & 4:00 AM & 17 & 2.30 & 5.97 & 5.66 & 0 \\
\hline $2 / 16 / 2017$ & Winter & 5:00 AM & 18 & 2.30 & 5.96 & 3.37 & 0 \\
\hline $2 / 16 / 2017$ & Winter & 6:00 AM & 19 & 2.31 & 5.96 & 2.09 & 0 \\
\hline $2 / 16 / 2017$ & Winter & 7:00 AM & & & & 4.10 & 0 \\
\hline $2 / 16 / 2017$ & Winter & $8: 00$ AM & & & & 5.35 & 10333 \\
\hline $2 / 16 / 2017$ & Winter & 9:00 AM & & & & 13.37 & 71645 \\
\hline $2 / 16 / 2017$ & Winter & 10:00 AM & & & & 17.48 & 115734 \\
\hline
\end{tabular}




\begin{tabular}{|c|c|c|c|c|c|c|c|}
\hline Date & Season & Time & $\begin{array}{l}\text { Order } \\
\text { in } \\
\text { Series }\end{array}$ & $\begin{array}{l}\mathrm{NO}_{3}^{-}-\mathrm{N} \\
(\mathrm{mg} / \mathrm{L})\end{array}$ & $\begin{array}{c}\mathrm{Cl}^{-} \\
(\mathrm{mg} / \mathrm{L})\end{array}$ & $\begin{array}{c}\text { Air } \\
\text { Temperature } \\
\text { (Hourly) }\left({ }^{\circ} \mathrm{C}\right)\end{array}$ & $\begin{array}{c}\text { Solar Intensity } \\
\text { (Hourly) (lux) }\end{array}$ \\
\hline $2 / 16 / 2017$ & Winter & 11:00 AM & & & & 20.62 & 154312 \\
\hline $2 / 16 / 2017$ & Winter & 12:00 PM & 1 & 2.13 & 6.05 & 9.47 & 46845 \\
\hline $2 / 16 / 2017$ & Winter & 1:00 PM & 2 & 2.16 & 5.94 & 12.88 & 42711 \\
\hline $2 / 16 / 2017$ & Winter & 2:00 PM & 3 & 2.18 & 5.91 & 13.75 & 88178 \\
\hline $2 / 16 / 2017$ & Winter & 3:00 PM & 4 & 2.20 & 5.89 & 15.28 & 82667 \\
\hline $2 / 16 / 2017$ & Winter & 4:00 PM & 5 & 2.20 & 5.89 & 15.28 & 33067 \\
\hline $2 / 16 / 2017$ & Winter & 5:00 PM & 6 & 2.20 & 5.89 & 13.17 & 8611 \\
\hline $2 / 16 / 2017$ & Winter & 6:00 PM & 7 & 2.21 & 5.90 & 12.69 & 6200 \\
\hline $2 / 16 / 2017$ & Winter & 7:00 PM & 8 & 2.22 & 5.91 & 9.28 & 0 \\
\hline $2 / 16 / 2017$ & Winter & 8:00 PM & 9 & 2.23 & 5.92 & 9.67 & 0 \\
\hline $2 / 16 / 2017$ & Winter & 9:00 PM & 10 & 2.24 & 5.91 & 8.08 & 0 \\
\hline $2 / 16 / 2017$ & Winter & 10:00 PM & 11 & 2.24 & 5.90 & 6.88 & 0 \\
\hline $2 / 16 / 2017$ & Winter & 11:00 PM & 12 & 2.25 & 5.92 & 6.37 & 0 \\
\hline $2 / 21 / 2017$ & Winter & $12: 00 \mathrm{AM}$ & 10 & 2.97 & 6.23 & 8.68 & 0 \\
\hline $2 / 21 / 2017$ & Winter & 1:00 AM & 11 & 2.98 & 6.25 & 8.38 & 0 \\
\hline $2 / 21 / 2017$ & Winter & 2:00 AM & 12 & 2.99 & 6.27 & 7.18 & 0 \\
\hline $2 / 21 / 2017$ & Winter & 3:00 AM & 13 & 3.00 & 6.25 & 5.04 & 0 \\
\hline $2 / 21 / 2017$ & Winter & 4:00 AM & 14 & 3.02 & 6.23 & 8.98 & 0 \\
\hline $2 / 21 / 2017$ & Winter & 5:00 AM & 15 & 3.02 & 6.24 & 9.97 & 0 \\
\hline $2 / 21 / 2017$ & Winter & $6: 00 \mathrm{AM}$ & 16 & 3.02 & 6.33 & 9.57 & 0 \\
\hline $2 / 21 / 2017$ & Winter & 7:00 AM & 17 & 3.03 & 6.26 & 9.87 & 0 \\
\hline $2 / 21 / 2017$ & Winter & $8: 00$ AM & 18 & 3.05 & 6.24 & 10.06 & 1216 \\
\hline $2 / 21 / 2017$ & Winter & 9:00 AM & 19 & 3.06 & 6.25 & 11.43 & 9300 \\
\hline $2 / 21 / 2017$ & Winter & $10: 00 \mathrm{AM}$ & 20 & 3.07 & 6.30 & 12.69 & 11022 \\
\hline $2 / 21 / 2017$ & Winter & $11: 00 \mathrm{AM}$ & 21 & 3.08 & 6.36 & 13.56 & 14467 \\
\hline $2 / 21 / 2017$ & Winter & 12:00 PM & 22 & 3.09 & 6.31 & 15.47 & 18600 \\
\hline $2 / 21 / 2017$ & Winter & 1:00 PM & 23 & 3.10 & 6.34 & 15.86 & 17911 \\
\hline $2 / 21 / 2017$ & Winter & 2:00 PM & 24 & 3.11 & 6.32 & 20.14 & 154312 \\
\hline $2 / 21 / 2017$ & Winter & 3:00 PM & 1 & 2.80 & 6.48 & 22.72 & 34445 \\
\hline $2 / 21 / 2017$ & Winter & 4:00 PM & 2 & 2.83 & 6.30 & 24.74 & 74401 \\
\hline $2 / 21 / 2017$ & Winter & 5:00 PM & 3 & 2.86 & 6.27 & 20.71 & 17911 \\
\hline $2 / 21 / 2017$ & Winter & 6:00 PM & 4 & 2.90 & 6.26 & 17.95 & 5339 \\
\hline $2 / 21 / 2017$ & Winter & 7:00 PM & 5 & 2.91 & 6.36 & 10.65 & 0 \\
\hline $2 / 21 / 2017$ & Winter & 8:00 PM & 6 & 2.92 & 6.24 & 10.06 & 0 \\
\hline $2 / 21 / 2017$ & Winter & 9:00 PM & 7 & 2.94 & 6.23 & 10.55 & 0 \\
\hline
\end{tabular}

(Table Continues) 


\begin{tabular}{|c|c|c|c|c|c|c|c|}
\hline Date & Season & Time & $\begin{array}{l}\text { Order } \\
\text { in } \\
\text { Series }\end{array}$ & $\begin{array}{l}\mathrm{NO}_{3}^{-}-\mathrm{N} \\
(\mathrm{mg} / \mathrm{L})\end{array}$ & $\begin{array}{c}\mathrm{Cl}^{-} \\
(\mathrm{mg} / \mathrm{L})\end{array}$ & $\begin{array}{c}\text { Air } \\
\text { Temperature } \\
\text { (Hourly) }\left({ }^{\circ} \mathrm{C}\right)\end{array}$ & $\begin{array}{c}\text { Solar Intensity } \\
\text { (Hourly) (lux) }\end{array}$ \\
\hline $2 / 21 / 2017$ & Winter & 10:00 PM & 8 & 2.96 & 6.24 & 10.16 & 0 \\
\hline $2 / 21 / 2017$ & Winter & 11:00 PM & 9 & 2.95 & 6.22 & 9.37 & 0 \\
\hline $2 / 28 / 2017$ & Winter & $12: 00 \mathrm{AM}$ & 13 & 4.83 & 6.91 & 11.92 & 0 \\
\hline $2 / 28 / 2017$ & Winter & 1:00 AM & 14 & 4.85 & 6.93 & 12.69 & 0 \\
\hline $2 / 28 / 2017$ & Winter & 2:00 AM & 15 & 4.85 & 6.94 & 13.27 & 0 \\
\hline $2 / 28 / 2017$ & Winter & 3:00 AM & 16 & 4.83 & 6.95 & 12.21 & 0 \\
\hline $2 / 28 / 2017$ & Winter & 4:00 AM & 17 & 4.83 & 7.05 & 11.92 & 0 \\
\hline $2 / 28 / 2017$ & Winter & 5:00 AM & 18 & 4.84 & 6.98 & 11.24 & 0 \\
\hline $2 / 28 / 2017$ & Winter & 6:00 AM & 19 & 4.85 & 7.14 & 10.36 & 0 \\
\hline $2 / 28 / 2017$ & Winter & 7:00 AM & 20 & 4.89 & 7.14 & 9.57 & 0 \\
\hline $2 / 28 / 2017$ & Winter & $8: 00$ AM & 21 & 4.88 & 7.14 & 7.88 & 151 \\
\hline $2 / 28 / 2017$ & Winter & 9:00 AM & 22 & 4.93 & 7.16 & 6.17 & 1636 \\
\hline $2 / 28 / 2017$ & Winter & 10:00 AM & 23 & 4.95 & 7.22 & 5.96 & 2497 \\
\hline $2 / 28 / 2017$ & Winter & 11:00 AM & 24 & 4.97 & 7.21 & 5.45 & 2325 \\
\hline $2 / 28 / 2017$ & Winter & 12:00 PM & 1 & 4.15 & 6.77 & 13.85 & 4306 \\
\hline $2 / 28 / 2017$ & Winter & 1:00 PM & 2 & 4.27 & 6.62 & 16.81 & 10333 \\
\hline $2 / 28 / 2017$ & Winter & 2:00 PM & 3 & 4.37 & 6.58 & 20.52 & 28934 \\
\hline $2 / 28 / 2017$ & Winter & 3:00 PM & 4 & 4.45 & 6.59 & 19.19 & 13778 \\
\hline $2 / 28 / 2017$ & Winter & 4:00 PM & 5 & 4.51 & 6.62 & 20.52 & 11022 \\
\hline $2 / 28 / 2017$ & Winter & 5:00 PM & 6 & 4.57 & 6.77 & 18.81 & 5167 \\
\hline $2 / 28 / 2017$ & Winter & 6:00 PM & 7 & 4.59 & 6.69 & 17.86 & 1722 \\
\hline $2 / 28 / 2017$ & Winter & 7:00 PM & 8 & 4.64 & 6.72 & 17.19 & 0 \\
\hline $2 / 28 / 2017$ & Winter & 8:00 PM & 9 & 4.68 & 6.76 & 17.00 & 0 \\
\hline $2 / 28 / 2017$ & Winter & 9:00 PM & 10 & 4.71 & 6.78 & 17.09 & 0 \\
\hline $2 / 28 / 2017$ & Winter & 10:00 PM & 11 & 4.75 & 6.97 & 16.81 & 0 \\
\hline $2 / 28 / 2017$ & Winter & 11:00 PM & 12 & 4.77 & 6.85 & 16.81 & 0 \\
\hline $3 / 7 / 2017$ & Winter & $12: 00 \mathrm{AM}$ & 8 & 4.89 & 6.57 & 5.14 & 0 \\
\hline $3 / 7 / 2017$ & Winter & 1:00 AM & 9 & 4.90 & 6.53 & 3.58 & 0 \\
\hline $3 / 7 / 2017$ & Winter & 2:00 AM & 10 & 4.90 & 6.52 & 3.37 & 0 \\
\hline $3 / 7 / 2017$ & Winter & 3:00 AM & 11 & 4.93 & 6.50 & 2.30 & 0 \\
\hline $3 / 7 / 2017$ & Winter & 4:00 AM & 12 & 4.95 & 6.48 & 1.44 & 0 \\
\hline $3 / 7 / 2017$ & Winter & 5:00 AM & & & & 0.89 & 0 \\
\hline $3 / 7 / 2017$ & Winter & 6:00 AM & & & & 0.89 & 0 \\
\hline $3 / 7 / 2017$ & Winter & 7:00 AM & & & & 1.22 & 97 \\
\hline $3 / 7 / 2017$ & Winter & $8: 00$ AM & & & & 4.83 & 33067 \\
\hline
\end{tabular}

(Table Continues) 


\begin{tabular}{|c|c|c|c|c|c|c|c|}
\hline Date & Season & Time & $\begin{array}{l}\text { Order } \\
\text { in } \\
\text { Series }\end{array}$ & $\begin{array}{l}\mathrm{NO}_{3}{ }^{-}-\mathrm{N} \\
(\mathrm{mg} / \mathrm{L})\end{array}$ & $\begin{array}{c}\mathrm{Cl}^{-} \\
(\mathrm{mg} / \mathrm{L})\end{array}$ & $\begin{array}{c}\text { Air } \\
\text { Temperature } \\
\text { (Hourly) }\left({ }^{\circ} \mathrm{C}\right)\end{array}$ & $\begin{array}{c}\text { Solar Intensity } \\
\text { (Hourly) (lux) }\end{array}$ \\
\hline $3 / 7 / 2017$ & Winter & 9:00 AM & & & & 8.78 & 66134 \\
\hline $3 / 7 / 2017$ & Winter & 10:00 AM & & & & 11.14 & 85423 \\
\hline $3 / 7 / 2017$ & Winter & 11:00 AM & & & & 13.65 & 93690 \\
\hline $3 / 7 / 2017$ & Winter & 12:00 PM & & & & 15.38 & 82667 \\
\hline $3 / 7 / 2017$ & Winter & 1:00 PM & & & & 16.43 & 30311 \\
\hline $3 / 7 / 2017$ & Winter & 2:00 PM & & & & 17.48 & 24800 \\
\hline $3 / 7 / 2017$ & Winter & 3:00 PM & & & & 17.76 & 20667 \\
\hline $3 / 7 / 2017$ & Winter & 4:00 PM & & & & 18.81 & 19289 \\
\hline $3 / 7 / 2017$ & Winter & 5:00 PM & 1 & 4.35 & 8.80 & 16.52 & 17222 \\
\hline $3 / 7 / 2017$ & Winter & 6:00 PM & 2 & 4.46 & 7.99 & 14.23 & 9300 \\
\hline $3 / 7 / 2017$ & Winter & 7:00 PM & 3 & 4.59 & 7.33 & 8.28 & 129 \\
\hline $3 / 7 / 2017$ & Winter & 8:00 PM & 4 & 4.70 & 6.91 & 4.21 & 0 \\
\hline $3 / 7 / 2017$ & Winter & 9:00 PM & 5 & 4.76 & 6.74 & 4.93 & 0 \\
\hline $3 / 7 / 2017$ & Winter & 10:00 PM & 6 & 4.82 & 6.65 & 6.06 & 0 \\
\hline $3 / 7 / 2017$ & Winter & 11:00 PM & 7 & 4.85 & 6.60 & 4.52 & 0 \\
\hline $3 / 20 / 2017$ & Spring & $12: 00$ AM & 15 & 5.91 & 6.75 & 4.83 & 0 \\
\hline $3 / 20 / 2017$ & Spring & 1:00 AM & 16 & 5.92 & 6.82 & 2.94 & 0 \\
\hline $3 / 20 / 2017$ & Spring & 2:00 AM & 17 & 5.92 & 6.77 & 3.26 & 0 \\
\hline $3 / 20 / 2017$ & Spring & 3:00 AM & 18 & 5.90 & 6.78 & 3.47 & 0 \\
\hline $3 / 20 / 2017$ & Spring & 4:00 AM & 19 & 5.93 & 6.77 & 2.41 & 0 \\
\hline $3 / 20 / 2017$ & Spring & 5:00 AM & 20 & 5.94 & 6.77 & 2.20 & 0 \\
\hline $3 / 20 / 2017$ & Spring & $6: 00$ AM & & & & 1.55 & 0 \\
\hline $3 / 20 / 2017$ & Spring & 7:00 AM & & & & 1.44 & 1087 \\
\hline $3 / 20 / 2017$ & Spring & $8: 00$ AM & & & & 6.06 & 15845 \\
\hline $3 / 20 / 2017$ & Spring & 9:00 AM & & & & 13.27 & 52356 \\
\hline $3 / 20 / 2017$ & Spring & $10: 00 \mathrm{AM}$ & 1 & 5.80 & 6.80 & 12.59 & 16533 \\
\hline $3 / 20 / 2017$ & Spring & $11: 00 \mathrm{AM}$ & 2 & 5.77 & 6.74 & 15.86 & 63378 \\
\hline $3 / 20 / 2017$ & Spring & 12:00 PM & 3 & 5.78 & 6.71 & 21.00 & 42711 \\
\hline $3 / 20 / 2017$ & Spring & 1:00 PM & 4 & 5.81 & 6.72 & 23.39 & 38578 \\
\hline $3 / 20 / 2017$ & Spring & 2:00 PM & 5 & 5.84 & 6.71 & 22.91 & 41334 \\
\hline $3 / 20 / 2017$ & Spring & 3:00 PM & 6 & 5.85 & 6.72 & 20.23 & 23422 \\
\hline $3 / 20 / 2017$ & Spring & 4:00 PM & 7 & 5.86 & 6.73 & 21.66 & 28934 \\
\hline $3 / 20 / 2017$ & Spring & 5:00 PM & 8 & 5.88 & 6.73 & 17.00 & 14467 \\
\hline $3 / 20 / 2017$ & Spring & 6:00 PM & 9 & 5.86 & 6.74 & 13.37 & 1895 \\
\hline $3 / 20 / 2017$ & Spring & 7:00 PM & 10 & 5.89 & 6.73 & 11.43 & 75 \\
\hline
\end{tabular}




\begin{tabular}{|c|c|c|c|c|c|c|c|}
\hline Date & Season & Time & $\begin{array}{l}\text { Order } \\
\text { in } \\
\text { Series } \\
\end{array}$ & $\begin{array}{l}\mathrm{NO}_{3}{ }^{-}-\mathrm{N} \\
(\mathrm{mg} / \mathrm{L})\end{array}$ & $\begin{array}{c}\mathrm{Cl}^{-} \\
(\mathrm{mg} / \mathrm{L})\end{array}$ & $\begin{array}{c}\text { Air } \\
\text { Temperature } \\
\text { (Hourly) }\left({ }^{\circ} \mathrm{C}\right) \\
\end{array}$ & $\begin{array}{l}\text { Solar Intensity } \\
\text { (Hourly) (lux) }\end{array}$ \\
\hline $3 / 20 / 2017$ & Spring & 8:00 PM & 11 & 5.90 & 6.75 & 10.36 & 0 \\
\hline $3 / 20 / 2017$ & Spring & 9:00 PM & 12 & 5.88 & 6.82 & 8.68 & 0 \\
\hline $3 / 20 / 2017$ & Spring & 10:00 PM & 13 & 5.91 & 6.84 & 7.38 & 0 \\
\hline $3 / 20 / 2017$ & Spring & 11:00 PM & 14 & 5.91 & 6.75 & 6.06 & 0 \\
\hline $3 / 24 / 2017$ & Spring & $12: 00$ AM & 8 & 5.61 & 6.69 & 14.52 & 0 \\
\hline $3 / 24 / 2017$ & Spring & 1:00 AM & 9 & 5.62 & 6.67 & 10.16 & 0 \\
\hline $3 / 24 / 2017$ & Spring & 2:00 AM & 10 & 5.61 & 6.68 & 9.08 & 0 \\
\hline $3 / 24 / 2017$ & Spring & 3:00 AM & 11 & 5.62 & 6.67 & 8.58 & 0 \\
\hline $3 / 24 / 2017$ & Spring & 4:00 AM & 12 & 5.62 & 6.69 & 8.18 & 0 \\
\hline $3 / 24 / 2017$ & Spring & 5:00 AM & 13 & 5.63 & 6.72 & 7.68 & 0 \\
\hline $3 / 24 / 2017$ & Spring & 6:00 AM & 14 & 5.62 & 6.73 & 7.48 & 0 \\
\hline $3 / 24 / 2017$ & Spring & 7:00 AM & 15 & 5.61 & 6.72 & 7.98 & 108 \\
\hline $3 / 24 / 2017$ & Spring & 8:00 AM & 16 & 5.60 & 6.71 & 8.58 & 1981 \\
\hline $3 / 24 / 2017$ & Spring & 9:00 AM & 17 & 5.61 & 6.71 & 11.04 & 12400 \\
\hline $3 / 24 / 2017$ & Spring & 10:00 AM & 18 & 5.61 & 6.71 & 15.00 & 34445 \\
\hline $3 / 24 / 2017$ & Spring & 11:00 AM & 19 & 5.61 & 6.72 & 20.23 & 42711 \\
\hline $3 / 24 / 2017$ & Spring & 12:00 PM & 20 & 5.61 & 6.70 & 17.48 & 6545 \\
\hline $3 / 24 / 2017$ & Spring & 1:00 PM & 21 & 5.63 & 6.72 & 15.86 & 6200 \\
\hline $3 / 24 / 2017$ & Spring & 2:00 PM & 22 & 5.62 & 6.72 & 16.14 & 10333 \\
\hline $3 / 24 / 2017$ & Spring & 3:00 PM & 23 & 5.62 & 6.73 & 16.05 & 10678 \\
\hline $3 / 24 / 2017$ & Spring & 4:00 PM & 24 & 5.62 & 6.74 & 16.62 & 5167 \\
\hline $3 / 24 / 2017$ & Spring & 5:00 PM & 1 & 5.58 & 6.75 & 24.55 & 8611 \\
\hline $3 / 24 / 2017$ & Spring & 6:00 PM & 2 & 5.57 & 6.65 & 22.81 & 2670 \\
\hline $3 / 24 / 2017$ & Spring & 7:00 PM & 3 & 5.57 & 6.66 & 21.00 & 162 \\
\hline $3 / 24 / 2017$ & Spring & 8:00 PM & 4 & 5.60 & 6.69 & 19.95 & 0 \\
\hline $3 / 24 / 2017$ & Spring & 9:00 PM & 5 & 5.60 & 6.66 & 18.24 & 0 \\
\hline $3 / 24 / 2017$ & Spring & 10:00 PM & 6 & 5.61 & 6.66 & 15.57 & 0 \\
\hline $3 / 24 / 2017$ & Spring & 11:00 PM & 7 & 5.61 & 6.67 & 14.23 & 0 \\
\hline $4 / 1 / 2017$ & Spring & $12: 00 \mathrm{AM}$ & 11 & 4.36 & 6.10 & 6.06 & 0 \\
\hline $4 / 1 / 2017$ & Spring & 1:00 AM & 12 & 4.36 & 6.11 & 5.55 & 0 \\
\hline $4 / 1 / 2017$ & Spring & 2:00 AM & 13 & 4.36 & 6.17 & 6.27 & 0 \\
\hline $4 / 1 / 2017$ & Spring & 3:00 AM & 14 & 4.34 & 6.10 & 6.78 & 0 \\
\hline $4 / 1 / 2017$ & Spring & 4:00 AM & 15 & 4.33 & 6.11 & 5.96 & 0 \\
\hline $4 / 1 / 2017$ & Spring & 5:00 AM & 16 & 4.31 & 6.12 & 6.67 & 0 \\
\hline $4 / 1 / 2017$ & Spring & $6: 00$ AM & 17 & 4.30 & 6.12 & 4.93 & 0 \\
\hline
\end{tabular}

(Table Continues) 


\begin{tabular}{|c|c|c|c|c|c|c|c|}
\hline Date & Season & Time & $\begin{array}{l}\text { Order } \\
\text { in } \\
\text { Series }\end{array}$ & $\begin{array}{l}\mathrm{NO}_{3}{ }^{-}-\mathrm{N} \\
(\mathrm{mg} / \mathrm{L})\end{array}$ & $\begin{array}{c}\mathrm{Cl}^{-} \\
(\mathrm{mg} / \mathrm{L})\end{array}$ & $\begin{array}{c}\text { Air } \\
\text { Temperature } \\
\text { (Hourly) }\left({ }^{\circ} \mathrm{C}\right)\end{array}$ & $\begin{array}{l}\text { Solar Intensity } \\
\text { (Hourly) (lux) }\end{array}$ \\
\hline $4 / 1 / 2017$ & Spring & 7:00 AM & 18 & 4.29 & 6.12 & 7.18 & 527 \\
\hline $4 / 1 / 2017$ & Spring & $8: 00$ AM & 19 & 4.29 & 6.12 & 8.68 & 4650 \\
\hline $4 / 1 / 2017$ & Spring & 9:00 AM & 20 & 4.29 & 6.11 & 9.37 & 5339 \\
\hline $4 / 1 / 2017$ & Spring & $10: 00 \mathrm{AM}$ & 21 & 4.27 & 6.11 & 9.57 & 5511 \\
\hline $4 / 1 / 2017$ & Spring & 11:00 AM & 22 & 4.27 & 6.12 & 15.86 & 60623 \\
\hline $4 / 1 / 2017$ & Spring & 12:00 PM & 23 & 4.25 & 6.13 & 18.05 & 49600 \\
\hline $4 / 1 / 2017$ & Spring & 1:00 PM & 24 & 4.26 & 6.13 & 15.76 & 27556 \\
\hline $4 / 1 / 2017$ & Spring & 2:00 PM & 1 & 4.30 & 6.11 & 19.76 & 27556 \\
\hline $4 / 1 / 2017$ & Spring & 3:00 PM & 2 & 4.30 & 6.09 & 22.33 & 26178 \\
\hline $4 / 1 / 2017$ & Spring & 4:00 PM & 3 & 4.34 & 6.11 & 22.24 & 28934 \\
\hline $4 / 1 / 2017$ & Spring & 5:00 PM & 4 & 4.36 & 6.09 & 21.00 & 20667 \\
\hline $4 / 1 / 2017$ & Spring & 6:00 PM & 5 & 4.36 & 6.07 & 14.23 & 7233 \\
\hline $4 / 1 / 2017$ & Spring & 7:00 PM & 6 & 4.35 & 6.10 & 11.24 & 786 \\
\hline $4 / 1 / 2017$ & Spring & 8:00 PM & 7 & 4.34 & 6.11 & 7.78 & 0 \\
\hline $4 / 1 / 2017$ & Spring & 9:00 PM & 8 & 4.37 & 6.09 & 6.27 & 0 \\
\hline $4 / 1 / 2017$ & Spring & 10:00 PM & 9 & 4.38 & 6.11 & 6.57 & 0 \\
\hline $4 / 1 / 2017$ & Spring & 11:00 PM & 10 & 4.37 & 6.12 & 6.78 & 0 \\
\hline $4 / 4 / 2017$ & Spring & $12: 00 \mathrm{AM}$ & 11 & 3.70 & 6.03 & 9.08 & 0 \\
\hline $4 / 4 / 2017$ & Spring & 1:00 AM & 12 & 3.69 & 6.03 & 7.68 & 0 \\
\hline $4 / 4 / 2017$ & Spring & 2:00 AM & 13 & 3.70 & 6.04 & 7.28 & 0 \\
\hline $4 / 4 / 2017$ & Spring & 3:00 AM & 14 & 3.67 & 6.02 & 6.67 & 0 \\
\hline $4 / 4 / 2017$ & Spring & 4:00 AM & 15 & 3.63 & 5.93 & 6.37 & 0 \\
\hline $4 / 4 / 2017$ & Spring & 5:00 AM & 16 & 3.57 & 5.80 & 6.06 & 0 \\
\hline $4 / 4 / 2017$ & Spring & 6:00 AM & 17 & 3.49 & 5.67 & 5.96 & 0 \\
\hline $4 / 4 / 2017$ & Spring & 7:00 AM & 18 & 3.42 & 5.52 & 5.86 & 258 \\
\hline $4 / 4 / 2017$ & Spring & $8: 00$ AM & 19 & 3.37 & 5.44 & 6.47 & 2153 \\
\hline $4 / 4 / 2017$ & Spring & $9: 00 \mathrm{AM}$ & 20 & 3.37 & 5.43 & 7.58 & 3445 \\
\hline $4 / 4 / 2017$ & Spring & $10: 00 \mathrm{AM}$ & 21 & 3.36 & 5.42 & 8.58 & 8267 \\
\hline $4 / 4 / 2017$ & Spring & $11: 00 \mathrm{AM}$ & 22 & 3.33 & 5.39 & 8.88 & 6545 \\
\hline $4 / 4 / 2017$ & Spring & $12: 00$ PM & 23 & 3.32 & 5.35 & 8.68 & 3272 \\
\hline $4 / 4 / 2017$ & Spring & 1:00 PM & 24 & 3.30 & 5.38 & 8.38 & 1808 \\
\hline $4 / 4 / 2017$ & Spring & 2:00 PM & 1 & 3.61 & 6.01 & 13.27 & 14467 \\
\hline $4 / 4 / 2017$ & Spring & 3:00 PM & 2 & 3.67 & 6.02 & 15.19 & 21356 \\
\hline $4 / 4 / 2017$ & Spring & 4:00 PM & 3 & 3.71 & 6.02 & 15.66 & 16533 \\
\hline $4 / 4 / 2017$ & Spring & 5:00 PM & 4 & 3.74 & 6.02 & 16.05 & 16533 \\
\hline
\end{tabular}




\begin{tabular}{|c|c|c|c|c|c|c|c|}
\hline Date & Season & Time & $\begin{array}{l}\text { Order } \\
\text { in } \\
\text { Series }\end{array}$ & $\begin{array}{l}\mathrm{NO}_{3}^{-}-\mathrm{N} \\
(\mathrm{mg} / \mathrm{L})\end{array}$ & $\begin{array}{c}\mathrm{Cl}^{-} \\
(\mathrm{mg} / \mathrm{L})\end{array}$ & $\begin{array}{c}\text { Air } \\
\text { Temperature } \\
\text { (Hourly) }\left({ }^{\circ} \mathrm{C}\right)\end{array}$ & $\begin{array}{c}\text { Solar Intensity } \\
\text { (Hourly) (lux) }\end{array}$ \\
\hline $4 / 4 / 2017$ & Spring & 6:00 PM & 5 & 3.76 & 6.00 & 13.85 & 6545 \\
\hline $4 / 4 / 2017$ & Spring & 7:00 PM & 6 & 3.77 & 6.03 & 11.24 & 1120 \\
\hline $4 / 4 / 2017$ & Spring & 8:00 PM & 7 & 3.76 & 6.05 & 10.06 & 0 \\
\hline $4 / 4 / 2017$ & Spring & 9:00 PM & 8 & 3.74 & 6.03 & 9.18 & 0 \\
\hline $4 / 4 / 2017$ & Spring & 10:00 PM & 9 & 3.72 & 6.03 & 9.87 & 0 \\
\hline $4 / 4 / 2017$ & Spring & 11:00 PM & 10 & 3.71 & 6.02 & 9.87 & 0 \\
\hline $4 / 11 / 2017$ & Spring & $12: 00 \mathrm{AM}$ & 15 & 2.45 & 5.76 & 1.76 & 0 \\
\hline 4/11/2017 & Spring & 1:00 AM & 16 & 2.45 & 5.87 & 1.22 & 0 \\
\hline 4/11/2017 & Spring & 2:00 AM & & & & 0.12 & 0 \\
\hline $4 / 11 / 2017$ & Spring & 3:00 AM & & & & 0.12 & 0 \\
\hline 4/11/2017 & Spring & 4:00 AM & & & & -0.10 & 0 \\
\hline $4 / 11 / 2017$ & Spring & 5:00 AM & & & & -0.89 & 0 \\
\hline $4 / 11 / 2017$ & Spring & $6: 00 \mathrm{AM}$ & & & & -0.55 & 32 \\
\hline $4 / 11 / 2017$ & Spring & 7:00 AM & & & & 4.93 & 13778 \\
\hline 4/11/2017 & Spring & 8:00 AM & & & & 12.30 & 24800 \\
\hline $4 / 11 / 2017$ & Spring & 9:00 AM & & & & 18.81 & 44089 \\
\hline $4 / 11 / 2017$ & Spring & 10:00 AM & 1 & 2.54 & 5.84 & 11.43 & 17222 \\
\hline $4 / 11 / 2017$ & Spring & 11:00 AM & 2 & 2.53 & 5.79 & 11.53 & 16533 \\
\hline $4 / 11 / 2017$ & Spring & 12:00 PM & 3 & 2.52 & 5.75 & 14.13 & 30311 \\
\hline $4 / 11 / 2017$ & Spring & 1:00 PM & 4 & 2.51 & 5.75 & 17.38 & 46845 \\
\hline $4 / 11 / 2017$ & Spring & 2:00 PM & 5 & 2.49 & 5.73 & 18.14 & 57867 \\
\hline 4/11/2017 & Spring & 3:00 PM & 6 & 2.48 & 5.73 & 19.95 & 49600 \\
\hline $4 / 11 / 2017$ & Spring & 4:00 PM & 7 & 2.47 & 5.73 & 19.28 & 24800 \\
\hline $4 / 11 / 2017$ & Spring & 5:00 PM & 8 & 2.47 & 5.74 & 21.38 & 33067 \\
\hline $4 / 11 / 2017$ & Spring & 6:00 PM & 9 & 2.47 & 5.74 & 20.33 & 17911 \\
\hline $4 / 11 / 2017$ & Spring & 7:00 PM & 10 & 2.46 & 5.75 & 15.38 & 5511 \\
\hline $4 / 11 / 2017$ & Spring & 8:00 PM & 11 & 2.45 & 5.74 & 7.28 & 0 \\
\hline 4/11/2017 & Spring & 9:00 PM & 12 & 2.45 & 5.74 & 4.10 & 0 \\
\hline 4/11/2017 & Spring & 10:00 PM & 13 & 2.45 & 5.75 & 2.30 & 0 \\
\hline $4 / 11 / 2017$ & Spring & 11:00 PM & 14 & 2.45 & 5.75 & 1.98 & 0 \\
\hline $4 / 18 / 2017$ & Spring & $12: 00 \mathrm{AM}$ & 12 & 2.18 & 5.49 & 16.43 & 0 \\
\hline 4/18/2017 & Spring & 1:00 AM & 13 & 2.29 & 5.70 & 16.90 & 0 \\
\hline $4 / 18 / 2017$ & Spring & 2:00 AM & 14 & 2.29 & 5.70 & 17.86 & 0 \\
\hline $4 / 18 / 2017$ & Spring & 3:00 AM & 15 & 2.28 & 5.70 & 17.38 & 0 \\
\hline 4/18/2017 & Spring & 4:00 AM & 16 & 2.30 & 5.80 & 17.09 & 0 \\
\hline
\end{tabular}

(Table Continues) 


\begin{tabular}{|c|c|c|c|c|c|c|c|}
\hline Date & Season & Time & $\begin{array}{l}\text { Order } \\
\text { in } \\
\text { Series }\end{array}$ & $\begin{array}{l}\mathrm{NO}_{3}{ }^{-}-\mathrm{N} \\
(\mathrm{mg} / \mathrm{L})\end{array}$ & $\begin{array}{c}\mathrm{Cl}^{-} \\
(\mathrm{mg} / \mathrm{L})\end{array}$ & $\begin{array}{c}\text { Air } \\
\text { Temperature } \\
\text { (Hourly) }\left({ }^{\circ} \mathrm{C}\right)\end{array}$ & $\begin{array}{c}\text { Solar Intensity } \\
\text { (Hourly) (lux) }\end{array}$ \\
\hline 4/18/2017 & Spring & 5:00 AM & 17 & 2.29 & 5.72 & 17.19 & 0 \\
\hline $4 / 18 / 2017$ & Spring & 6:00 AM & 18 & 2.30 & 5.82 & 16.62 & 86 \\
\hline $4 / 18 / 2017$ & Spring & 7:00 AM & 19 & 2.30 & 5.72 & 17.86 & 7233 \\
\hline $4 / 18 / 2017$ & Spring & $8: 00$ AM & 20 & 2.30 & 5.82 & 19.19 & 7233 \\
\hline $4 / 18 / 2017$ & Spring & 9:00 AM & 21 & 2.30 & 5.73 & 19.66 & 11711 \\
\hline $4 / 18 / 2017$ & Spring & 10:00 AM & 22 & 2.30 & 5.72 & 21.66 & 20667 \\
\hline $4 / 18 / 2017$ & Spring & 11:00 AM & 23 & 2.31 & 5.83 & 23.87 & 44089 \\
\hline $4 / 18 / 2017$ & Spring & 12:00 PM & 24 & 2.31 & 5.73 & 30.86 & 55112 \\
\hline $4 / 18 / 2017$ & Spring & 1:00 PM & 1 & 2.26 & 5.72 & 28.26 & 49600 \\
\hline $4 / 18 / 2017$ & Spring & 2:00 PM & 2 & 2.28 & 5.71 & 28.46 & 44089 \\
\hline $4 / 18 / 2017$ & Spring & 3:00 PM & 3 & 2.27 & 5.69 & 27.86 & 35823 \\
\hline $4 / 18 / 2017$ & Spring & 4:00 PM & 4 & 2.26 & 5.68 & 29.45 & 46845 \\
\hline $4 / 18 / 2017$ & Spring & 5:00 PM & 5 & 2.25 & 5.76 & 32.39 & 37200 \\
\hline $4 / 18 / 2017$ & Spring & 6:00 PM & 6 & 2.26 & 5.69 & 29.25 & 18600 \\
\hline $4 / 18 / 2017$ & Spring & 7:00 PM & 7 & 2.26 & 5.69 & 24.35 & 5339 \\
\hline 4/18/2017 & Spring & 8:00 PM & 8 & 2.26 & 5.78 & 19.00 & 0 \\
\hline 4/18/2017 & Spring & 9:00 PM & 9 & 2.27 & 5.69 & 18.14 & 0 \\
\hline 4/18/2017 & Spring & 10:00 PM & 10 & 2.28 & 5.80 & 16.14 & 0 \\
\hline $4 / 18 / 2017$ & Spring & 11:00 PM & 11 & 2.28 & 5.70 & 16.43 & 0 \\
\hline $4 / 25 / 2017$ & Spring & $12: 00 \mathrm{AM}$ & 9 & 2.46 & 5.56 & 19.57 & 0 \\
\hline $4 / 25 / 2017$ & Spring & 1:00 AM & 10 & 2.46 & 5.56 & 18.71 & 0 \\
\hline $4 / 25 / 2017$ & Spring & 2:00 AM & 11 & 2.46 & 5.56 & 18.14 & 0 \\
\hline $4 / 25 / 2017$ & Spring & 3:00 AM & 12 & 2.47 & 5.57 & 17.76 & 0 \\
\hline $4 / 25 / 2017$ & Spring & 4:00 AM & 13 & 2.47 & 5.56 & 17.57 & 0 \\
\hline $4 / 25 / 2017$ & Spring & 5:00 AM & 14 & 2.46 & 5.57 & 17.95 & 0 \\
\hline $4 / 25 / 2017$ & Spring & $6: 00 \mathrm{AM}$ & 15 & 2.46 & 5.57 & 18.52 & 22 \\
\hline $4 / 25 / 2017$ & Spring & 7:00 AM & 16 & 2.47 & 5.58 & 17.19 & 829 \\
\hline $4 / 25 / 2017$ & Spring & $8: 00$ AM & 17 & 2.46 & 5.58 & 20.23 & 20667 \\
\hline $4 / 25 / 2017$ & Spring & 9:00 AM & 18 & 2.46 & 5.58 & 25.22 & 49600 \\
\hline $4 / 25 / 2017$ & Spring & $10: 00 \mathrm{AM}$ & 19 & 2.46 & 5.58 & 22.62 & 42711 \\
\hline $4 / 25 / 2017$ & Spring & $11: 00 \mathrm{AM}$ & 20 & 2.45 & 5.58 & 22.81 & 26178 \\
\hline $4 / 25 / 2017$ & Spring & 12:00 PM & 21 & 2.46 & 5.58 & 21.38 & 17222 \\
\hline $4 / 25 / 2017$ & Spring & 1:00 PM & 22 & 2.45 & 5.58 & 22.24 & 37200 \\
\hline $4 / 25 / 2017$ & Spring & 2:00 PM & 23 & 2.45 & 5.59 & 29.35 & 46845 \\
\hline $4 / 25 / 2017$ & Spring & 3:00 PM & 24 & 2.45 & 5.58 & 23.29 & 10678 \\
\hline
\end{tabular}




\begin{tabular}{|c|c|c|c|c|c|c|c|}
\hline Date & Season & Time & $\begin{array}{l}\text { Order } \\
\text { in } \\
\text { Series } \\
\end{array}$ & $\begin{array}{l}\mathrm{NO}_{3}{ }^{-} \mathrm{N} \\
(\mathrm{mg} / \mathrm{L})\end{array}$ & $\begin{array}{c}\mathrm{Cl}^{-} \\
(\mathrm{mg} / \mathrm{L})\end{array}$ & $\begin{array}{c}\text { Air } \\
\text { Temperature } \\
\text { (Hourly) }\left({ }^{\circ} \mathrm{C}\right) \\
\end{array}$ & $\begin{array}{l}\text { Solar Intensity } \\
\text { (Hourly) (lux) }\end{array}$ \\
\hline $4 / 25 / 2017$ & Spring & 4:00 PM & 1 & 2.33 & 5.74 & 31.17 & 41334 \\
\hline $4 / 25 / 2017$ & Spring & 5:00 PM & 2 & 2.38 & 5.63 & 28.26 & 17222 \\
\hline $4 / 25 / 2017$ & Spring & 6:00 PM & 3 & 2.40 & 5.57 & 25.42 & 5511 \\
\hline $4 / 25 / 2017$ & Spring & 7:00 PM & 4 & 2.43 & 5.55 & 24.16 & 3445 \\
\hline $4 / 25 / 2017$ & Spring & 8:00 PM & 5 & 2.44 & 5.54 & 22.24 & 0 \\
\hline $4 / 25 / 2017$ & Spring & 9:00 PM & 6 & 2.45 & 5.54 & 21.19 & 0 \\
\hline $4 / 25 / 2017$ & Spring & 10:00 PM & 7 & 2.46 & 5.56 & 20.33 & 0 \\
\hline $4 / 25 / 2017$ & Spring & 11:00 PM & 8 & 2.46 & 5.56 & 19.66 & 0 \\
\hline $5 / 9 / 2017$ & Spring & $12: 00$ AM & 13 & 1.24 & 4.96 & 13.08 & 0 \\
\hline $5 / 9 / 2017$ & Spring & 1:00 AM & 14 & 1.24 & 4.98 & 12.50 & 0 \\
\hline $5 / 9 / 2017$ & Spring & 2:00 AM & 15 & 1.25 & 4.99 & 12.88 & 0 \\
\hline $5 / 9 / 2017$ & Spring & 3:00 AM & 16 & 1.21 & 4.99 & 12.01 & 0 \\
\hline $5 / 9 / 2017$ & Spring & 4:00 AM & 17 & 1.19 & 4.99 & 12.30 & 0 \\
\hline $5 / 9 / 2017$ & Spring & 5:00 AM & 18 & 1.20 & 5.00 & 12.59 & 0 \\
\hline $5 / 9 / 2017$ & Spring & 6:00 AM & 19 & 1.25 & 5.01 & 11.92 & 1464 \\
\hline $5 / 9 / 2017$ & Spring & 7:00 AM & 20 & 1.25 & 5.01 & 15.66 & 21356 \\
\hline $5 / 9 / 2017$ & Spring & 8:00 AM & 21 & 1.25 & 5.03 & 20.52 & 35823 \\
\hline $5 / 9 / 2017$ & Spring & 9:00 AM & 22 & 1.23 & 5.01 & 23.68 & 46845 \\
\hline $5 / 9 / 2017$ & Spring & 10:00 AM & 23 & 1.21 & 5.03 & 26.10 & 49600 \\
\hline $5 / 9 / 2017$ & Spring & 11:00 AM & 24 & 1.23 & 5.03 & 28.26 & 49600 \\
\hline $5 / 9 / 2017$ & Spring & 12:00 PM & 1 & 1.17 & 4.96 & 29.85 & 55112 \\
\hline $5 / 9 / 2017$ & Spring & 1:00 PM & 2 & 1.14 & 4.96 & 32.91 & 55112 \\
\hline $5 / 9 / 2017$ & Spring & 2:00 PM & 3 & 1.20 & 4.94 & 28.06 & 44089 \\
\hline $5 / 9 / 2017$ & Spring & 3:00 PM & 4 & 1.20 & 4.94 & 28.06 & 42711 \\
\hline $5 / 9 / 2017$ & Spring & 4:00 PM & 5 & 1.21 & 4.94 & 29.65 & 35823 \\
\hline $5 / 9 / 2017$ & Spring & 5:00 PM & 6 & 1.21 & 4.92 & 30.26 & 34445 \\
\hline $5 / 9 / 2017$ & Spring & 6:00 PM & 7 & 1.21 & 4.94 & 26.68 & 19289 \\
\hline $5 / 9 / 2017$ & Spring & 7:00 PM & 8 & 1.22 & 4.95 & 18.90 & 5167 \\
\hline $5 / 9 / 2017$ & Spring & 8:00 PM & 9 & 1.23 & 4.96 & 15.66 & 237 \\
\hline $5 / 9 / 2017$ & Spring & 9:00 PM & 10 & 1.23 & 4.96 & 14.42 & 0 \\
\hline $5 / 9 / 2017$ & Spring & 10:00 PM & 11 & 1.23 & 4.96 & 13.75 & 0 \\
\hline $5 / 9 / 2017$ & Spring & 11:00 PM & 12 & 1.24 & 4.97 & 13.56 & 0 \\
\hline $5 / 15 / 2017$ & Spring & $12: 00$ AM & 10 & 2.01 & 5.46 & 20.62 & 0 \\
\hline $5 / 15 / 2017$ & Spring & 1:00 AM & 11 & 2.01 & 5.48 & 20.14 & 0 \\
\hline $5 / 15 / 2017$ & Spring & 2:00 AM & 12 & 2.02 & 5.46 & 18.05 & 0 \\
\hline
\end{tabular}

(Table Continues) 


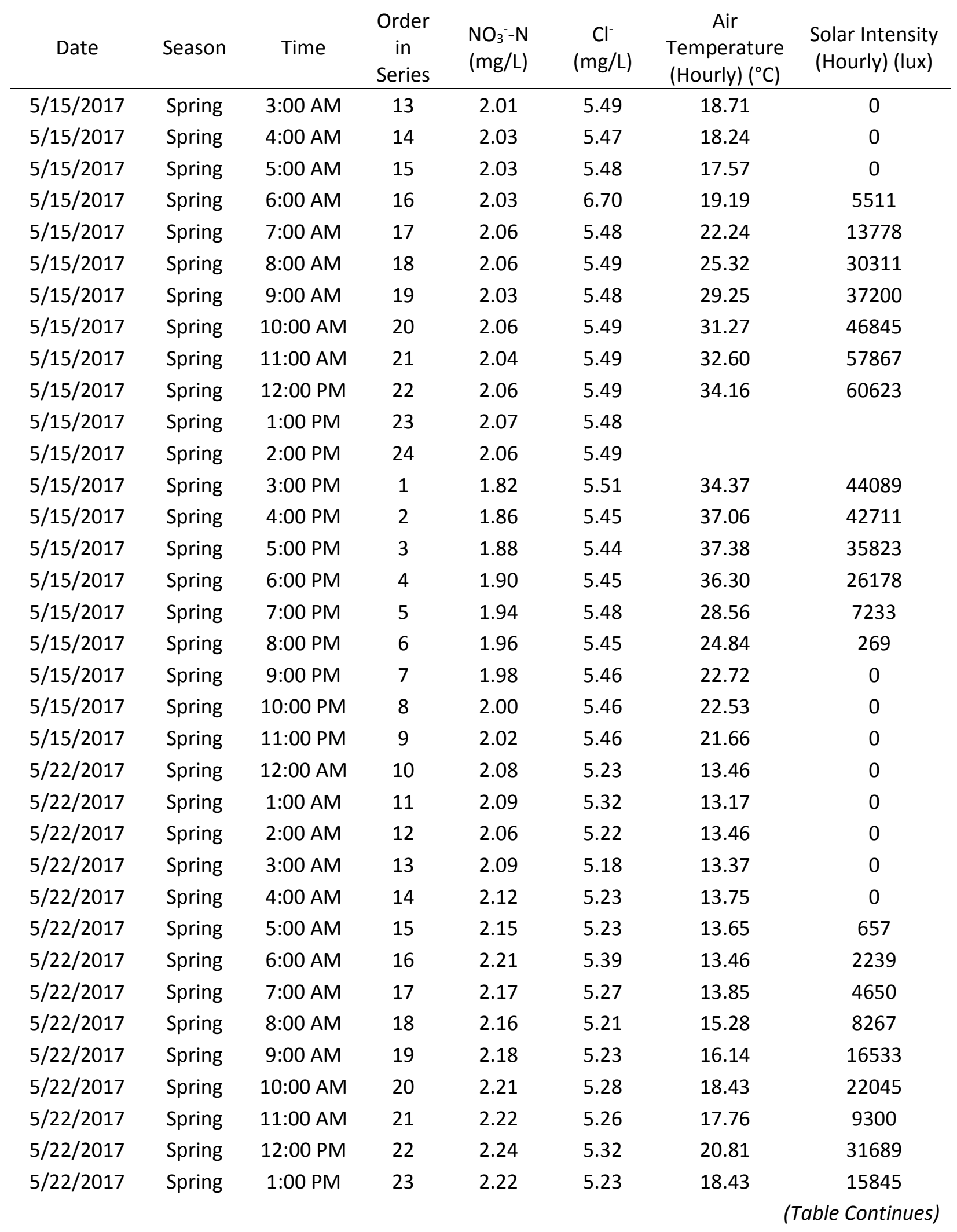




\begin{tabular}{|c|c|c|c|c|c|c|c|}
\hline Date & Season & Time & $\begin{array}{l}\text { Order } \\
\text { in } \\
\text { Series }\end{array}$ & $\begin{array}{l}\mathrm{NO}_{3}{ }^{-}-\mathrm{N} \\
(\mathrm{mg} / \mathrm{L})\end{array}$ & $\begin{array}{c}\mathrm{Cl}^{-} \\
(\mathrm{mg} / \mathrm{L})\end{array}$ & $\begin{array}{c}\text { Air } \\
\text { Temperature } \\
\text { (Hourly) }\left({ }^{\circ} \mathrm{C}\right)\end{array}$ & $\begin{array}{c}\text { Solar Intensity } \\
\text { (Hourly) (lux) }\end{array}$ \\
\hline $5 / 22 / 2017$ & Spring & 2:00 PM & 24 & 2.16 & 5.18 & 19.19 & 27556 \\
\hline $5 / 22 / 2017$ & Spring & 3:00 PM & 1 & 1.47 & 4.93 & 22.81 & 15845 \\
\hline $5 / 22 / 2017$ & Spring & 4:00 PM & 2 & 1.65 & 5.15 & 20.33 & 5167 \\
\hline $5 / 22 / 2017$ & Spring & 5:00 PM & 3 & 1.72 & 5.13 & 15.76 & 4995 \\
\hline $5 / 22 / 2017$ & Spring & 6:00 PM & 4 & 1.88 & 5.15 & 15.19 & 1636 \\
\hline $5 / 22 / 2017$ & Spring & 7:00 PM & 5 & 1.95 & 5.19 & 14.42 & 205 \\
\hline $5 / 22 / 2017$ & Spring & 8:00 PM & 6 & 1.95 & 5.21 & 14.23 & 0 \\
\hline $5 / 22 / 2017$ & Spring & 9:00 PM & 7 & 2.02 & 5.21 & 14.90 & 0 \\
\hline $5 / 22 / 2017$ & Spring & 10:00 PM & 8 & 1.97 & 5.09 & 14.23 & 0 \\
\hline $5 / 22 / 2017$ & Spring & 11:00 PM & 9 & 1.99 & 5.19 & 14.23 & 0 \\
\hline $5 / 29 / 2017$ & Spring & $12: 00 \mathrm{AM}$ & 10 & 3.63 & 5.78 & 14.71 & 0 \\
\hline $5 / 29 / 2017$ & Spring & 1:00 AM & 11 & 3.68 & 5.80 & 12.50 & 0 \\
\hline $5 / 29 / 2017$ & Spring & 2:00 AM & 12 & 3.74 & 5.75 & 8.08 & 0 \\
\hline $5 / 29 / 2017$ & Spring & 3:00 AM & 13 & 3.69 & 5.82 & 7.18 & 0 \\
\hline $5 / 29 / 2017$ & Spring & 4:00 AM & 14 & 3.87 & 5.93 & 7.98 & 0 \\
\hline $5 / 29 / 2017$ & Spring & 5:00 AM & 15 & 3.87 & 5.86 & 11.14 & 9300 \\
\hline $5 / 29 / 2017$ & Spring & $6: 00 \mathrm{AM}$ & 16 & 3.85 & 5.84 & 20.04 & 24800 \\
\hline $5 / 29 / 2017$ & Spring & 7:00 AM & 17 & 3.58 & 5.42 & 22.53 & 35823 \\
\hline $5 / 29 / 2017$ & Spring & $8: 00$ AM & 18 & 3.91 & 5.92 & 24.26 & 42711 \\
\hline $5 / 29 / 2017$ & Spring & 9:00 AM & 19 & 3.80 & 5.86 & 25.90 & 52356 \\
\hline $5 / 29 / 2017$ & Spring & 10:00 AM & 20 & 3.90 & 5.92 & 26.98 & 63378 \\
\hline $5 / 29 / 2017$ & Spring & 11:00 AM & 21 & 3.93 & 5.88 & 28.16 & 57867 \\
\hline $5 / 29 / 2017$ & Spring & 12:00 PM & 22 & 3.96 & 6.00 & 26.88 & 63378 \\
\hline $5 / 29 / 2017$ & Spring & 1:00 PM & 23 & 3.92 & 5.94 & 27.57 & 24800 \\
\hline $5 / 29 / 2017$ & Spring & 2:00 PM & 24 & 3.98 & 6.21 & 28.85 & 26178 \\
\hline $5 / 29 / 2017$ & Spring & 3:00 PM & 1 & 2.91 & 5.77 & 31.17 & 52356 \\
\hline $5 / 29 / 2017$ & Spring & 4:00 PM & 2 & 3.03 & 5.64 & 33.43 & 34445 \\
\hline $5 / 29 / 2017$ & Spring & 5:00 PM & 3 & 1.48 & 2.69 & 32.19 & 26178 \\
\hline $5 / 29 / 2017$ & Spring & 6:00 PM & 4 & 3.48 & 5.77 & 23.68 & 5511 \\
\hline $5 / 29 / 2017$ & Spring & 7:00 PM & 5 & 3.57 & 5.73 & 20.90 & 3445 \\
\hline $5 / 29 / 2017$ & Spring & 8:00 PM & 6 & 3.63 & 5.75 & 12.50 & 0 \\
\hline $5 / 29 / 2017$ & Spring & 9:00 PM & 7 & 3.59 & 5.76 & 9.77 & 0 \\
\hline $5 / 29 / 2017$ & Spring & 10:00 PM & 8 & 3.74 & 5.81 & 15.38 & 0 \\
\hline $5 / 29 / 2017$ & Spring & 11:00 PM & 9 & 3.72 & 5.77 & 14.42 & 0 \\
\hline $6 / 6 / 2017$ & Spring & $12: 00 \mathrm{AM}$ & 15 & 4.75 & 6.27 & 11.24 & 0 \\
\hline
\end{tabular}

(Table Continues) 


\begin{tabular}{|c|c|c|c|c|c|c|c|}
\hline Date & Season & Time & $\begin{array}{l}\text { Order } \\
\text { in } \\
\text { Series }\end{array}$ & $\begin{array}{l}\mathrm{NO}_{3}{ }^{-}-\mathrm{N} \\
(\mathrm{mg} / \mathrm{L})\end{array}$ & $\begin{array}{c}\mathrm{Cl}^{-} \\
(\mathrm{mg} / \mathrm{L})\end{array}$ & $\begin{array}{c}\text { Air } \\
\text { Temperature } \\
\text { (Hourly) }\left({ }^{\circ} \mathrm{C}\right)\end{array}$ & $\begin{array}{l}\text { Solar Intensity } \\
\text { (Hourly) (lux) }\end{array}$ \\
\hline $6 / 6 / 2017$ & Spring & 1:00 AM & 16 & 4.84 & 6.35 & 8.28 & 0 \\
\hline $6 / 6 / 2017$ & Spring & 2:00 AM & 17 & 4.85 & 6.40 & 7.58 & 0 \\
\hline $6 / 6 / 2017$ & Spring & 3:00 AM & 18 & 4.85 & 6.36 & 6.17 & 0 \\
\hline $6 / 6 / 2017$ & Spring & 4:00 AM & 19 & 4.91 & 6.43 & 5.96 & 0 \\
\hline $6 / 6 / 2017$ & Spring & 5:00 AM & 20 & 4.90 & 6.39 & 11.43 & 11022 \\
\hline $6 / 6 / 2017$ & Spring & 6:00 AM & 21 & 4.86 & 6.45 & 21.28 & 27556 \\
\hline $6 / 6 / 2017$ & Spring & 7:00 AM & 22 & 4.89 & 6.50 & 22.72 & 28934 \\
\hline $6 / 6 / 2017$ & Spring & $8: 00$ AM & 23 & 4.84 & 6.31 & 25.03 & 46845 \\
\hline $6 / 6 / 2017$ & Spring & 9:00 AM & 24 & 4.86 & 6.38 & 26.39 & 55112 \\
\hline $6 / 6 / 2017$ & Spring & $10: 00 \mathrm{AM}$ & 1 & 4.45 & 6.75 & 29.35 & 63378 \\
\hline $6 / 6 / 2017$ & Spring & $11: 00 \mathrm{AM}$ & 2 & 4.50 & 6.50 & 28.36 & 38578 \\
\hline $6 / 6 / 2017$ & Spring & 12:00 PM & 3 & 4.63 & 6.38 & 30.86 & 37200 \\
\hline $6 / 6 / 2017$ & Spring & 1:00 PM & 4 & 4.66 & 6.35 & 32.29 & 37200 \\
\hline $6 / 6 / 2017$ & Spring & 2:00 PM & 5 & 3.82 & 5.29 & 32.39 & 38578 \\
\hline $6 / 6 / 2017$ & Spring & 3:00 PM & 6 & 4.63 & 6.23 & 32.19 & 34445 \\
\hline $6 / 6 / 2017$ & Spring & 4:00 PM & 7 & 4.71 & 6.48 & 29.75 & 28934 \\
\hline $6 / 6 / 2017$ & Spring & 5:00 PM & 8 & 4.82 & 6.43 & 28.26 & 23422 \\
\hline $6 / 6 / 2017$ & Spring & 6:00 PM & 9 & 4.73 & 6.27 & 23.20 & 4650 \\
\hline $6 / 6 / 2017$ & Spring & 7:00 PM & 10 & 4.69 & 6.18 & 22.43 & 5167 \\
\hline $6 / 6 / 2017$ & Spring & 8:00 PM & 11 & 4.71 & 6.39 & 17.67 & 0 \\
\hline $6 / 6 / 2017$ & Spring & 9:00 PM & 12 & 4.74 & 6.27 & 15.28 & 0 \\
\hline $6 / 6 / 2017$ & Spring & 10:00 PM & 13 & 4.89 & 6.49 & 12.59 & 0 \\
\hline $6 / 6 / 2017$ & Spring & 11:00 PM & 14 & 4.89 & 6.44 & 8.38 & 0 \\
\hline $6 / 13 / 2017$ & Spring & $12: 00 \mathrm{AM}$ & 15 & 5.17 & 6.68 & 23.87 & 0 \\
\hline $6 / 13 / 2017$ & Spring & 1:00 AM & 16 & 5.15 & 6.62 & 23.10 & 0 \\
\hline $6 / 13 / 2017$ & Spring & 2:00 AM & 17 & 4.66 & 6.19 & 22.72 & 0 \\
\hline $6 / 13 / 2017$ & Spring & $3: 00$ AM & 18 & 5.10 & 6.60 & 22.33 & 0 \\
\hline $6 / 13 / 2017$ & Spring & 4:00 AM & 19 & 4.36 & 5.73 & 22.14 & 0 \\
\hline $6 / 13 / 2017$ & Spring & 5:00 AM & 20 & 4.01 & 5.28 & 24.55 & 7233 \\
\hline $6 / 13 / 2017$ & Spring & $6: 00 \mathrm{AM}$ & 21 & 5.02 & 6.53 & 30.15 & 26178 \\
\hline $6 / 13 / 2017$ & Spring & 7:00 AM & 22 & 4.29 & 5.67 & 32.29 & 35823 \\
\hline $6 / 13 / 2017$ & Spring & $8: 00$ AM & 23 & 3.78 & 5.02 & 32.50 & 33067 \\
\hline $6 / 13 / 2017$ & Spring & 9:00 AM & 24 & & & 37.60 & 57867 \\
\hline $6 / 13 / 2017$ & Spring & $10: 00 \mathrm{AM}$ & 1 & 4.38 & 6.63 & 39.84 & 74401 \\
\hline $6 / 13 / 2017$ & Spring & 11:00 AM & 2 & 4.69 & 6.58 & 39.73 & 77156 \\
\hline
\end{tabular}




\begin{tabular}{|c|c|c|c|c|c|c|c|}
\hline Date & Season & Time & $\begin{array}{l}\text { Order } \\
\text { in } \\
\text { Series }\end{array}$ & $\begin{array}{l}\mathrm{NO}_{3}^{-}-\mathrm{N} \\
(\mathrm{mg} / \mathrm{L})\end{array}$ & $\begin{array}{c}\mathrm{Cl}^{-} \\
(\mathrm{mg} / \mathrm{L})\end{array}$ & $\begin{array}{c}\text { Air } \\
\text { Temperature } \\
\text { (Hourly) }\left({ }^{\circ} \mathrm{C}\right)\end{array}$ & $\begin{array}{c}\text { Solar Intensity } \\
\text { (Hourly) (lux) }\end{array}$ \\
\hline $6 / 13 / 2017$ & Spring & 12:00 PM & 3 & 4.89 & 6.55 & 42.28 & 52356 \\
\hline $6 / 13 / 2017$ & Spring & 1:00 PM & 4 & 4.67 & 6.35 & 39.05 & 42711 \\
\hline $6 / 13 / 2017$ & Spring & 2:00 PM & 5 & 4.84 & 6.53 & 42.28 & 49600 \\
\hline $6 / 13 / 2017$ & Spring & 3:00 PM & 6 & 4.96 & 6.65 & 39.39 & 44089 \\
\hline $6 / 13 / 2017$ & Spring & 4:00 PM & 7 & 5.02 & 6.72 & 37.06 & 38578 \\
\hline $6 / 13 / 2017$ & Spring & 5:00 PM & 8 & 3.20 & 4.37 & 40.07 & 27556 \\
\hline $6 / 13 / 2017$ & Spring & 6:00 PM & 9 & 5.05 & 6.73 & 33.01 & 6200 \\
\hline $6 / 13 / 2017$ & Spring & 7:00 PM & 10 & 5.07 & 6.59 & 32.39 & 4995 \\
\hline $6 / 13 / 2017$ & Spring & 8:00 PM & 11 & 4.22 & 5.54 & 25.51 & 0 \\
\hline $6 / 13 / 2017$ & Spring & 9:00 PM & 12 & 5.10 & 6.70 & 24.06 & 0 \\
\hline $6 / 13 / 2017$ & Spring & 10:00 PM & 13 & 4.52 & 5.90 & 23.87 & 0 \\
\hline $6 / 13 / 2017$ & Spring & 11:00 PM & 14 & 5.09 & 6.61 & 23.39 & 0 \\
\hline $6 / 20 / 2017$ & Summer & $12: 00 \mathrm{AM}$ & 16 & 3.57 & 5.80 & 16.33 & 0 \\
\hline $6 / 20 / 2017$ & Summer & 1:00 AM & 17 & 3.58 & 5.81 & 16.62 & 0 \\
\hline $6 / 20 / 2017$ & Summer & 2:00 AM & 18 & 3.54 & 5.82 & 16.52 & 0 \\
\hline $6 / 20 / 2017$ & Summer & $3: 00$ AM & 19 & 3.67 & 5.87 & 15.28 & 0 \\
\hline $6 / 20 / 2017$ & Summer & 4:00 AM & 20 & 3.54 & 5.83 & 15.19 & 11 \\
\hline $6 / 20 / 2017$ & Summer & 5:00 AM & 21 & 3.58 & 5.84 & 16.43 & 3272 \\
\hline $6 / 20 / 2017$ & Summer & 6:00 AM & 22 & 3.53 & 5.84 & 21.38 & 24800 \\
\hline $6 / 20 / 2017$ & Summer & 7:00 AM & 23 & 3.51 & 5.84 & 23.97 & 34445 \\
\hline $6 / 20 / 2017$ & Summer & $8: 00$ AM & 24 & 3.56 & 5.87 & 27.67 & 44089 \\
\hline $6 / 20 / 2017$ & Summer & 9:00 AM & 1 & 3.16 & 5.56 & 31.27 & 44089 \\
\hline $6 / 20 / 2017$ & Summer & $10: 00 \mathrm{AM}$ & 2 & 3.26 & 5.58 & 32.81 & 66134 \\
\hline $6 / 20 / 2017$ & Summer & $11: 00 \mathrm{AM}$ & 3 & 3.38 & 5.59 & 33.95 & 66134 \\
\hline $6 / 20 / 2017$ & Summer & $12: 00$ PM & 4 & 3.42 & 5.61 & 33.85 & 38578 \\
\hline 6/20/2017 & Summer & 1:00 PM & 5 & 3.47 & 5.64 & 34.90 & 34445 \\
\hline $6 / 20 / 2017$ & Summer & 2:00 PM & 6 & 3.47 & 5.65 & 36.08 & 37200 \\
\hline $6 / 20 / 2017$ & Summer & 3:00 PM & 7 & 3.50 & 5.69 & 31.17 & 16533 \\
\hline $6 / 20 / 2017$ & Summer & 4:00 PM & 8 & 3.64 & 5.75 & 33.85 & 37200 \\
\hline $6 / 20 / 2017$ & Summer & 5:00 PM & 9 & 3.53 & 5.74 & 32.39 & 28934 \\
\hline $6 / 20 / 2017$ & Summer & 6:00 PM & 10 & 3.54 & 5.75 & 25.71 & 5167 \\
\hline $6 / 20 / 2017$ & Summer & 7:00 PM & 11 & 3.55 & 5.77 & 20.23 & 8267 \\
\hline $6 / 20 / 2017$ & Summer & 8:00 PM & 12 & 3.57 & 5.78 & 17.95 & 0 \\
\hline $6 / 20 / 2017$ & Summer & 9:00 PM & 13 & 3.55 & 5.78 & 16.90 & 0 \\
\hline $6 / 20 / 2017$ & Summer & 10:00 PM & 14 & 3.60 & 5.80 & 16.24 & 0 \\
\hline
\end{tabular}

(Table Continues) 


\begin{tabular}{|c|c|c|c|c|c|c|c|}
\hline Date & Season & Time & $\begin{array}{l}\text { Order } \\
\text { in } \\
\text { Series } \\
\end{array}$ & $\begin{array}{l}\mathrm{NO}_{3}^{-}-\mathrm{N} \\
(\mathrm{mg} / \mathrm{L})\end{array}$ & $\begin{array}{c}\mathrm{Cl}^{-} \\
(\mathrm{mg} / \mathrm{L})\end{array}$ & $\begin{array}{c}\text { Air } \\
\text { Temperature } \\
\text { (Hourly) }\left({ }^{\circ} \mathrm{C}\right) \\
\end{array}$ & $\begin{array}{c}\text { Solar Intensity } \\
\text { (Hourly) (lux) }\end{array}$ \\
\hline $6 / 20 / 2017$ & Summer & 11:00 PM & 15 & 3.55 & 5.79 & 16.43 & 0 \\
\hline $6 / 27 / 2017$ & Summer & $12: 00$ AM & 13 & 3.19 & 5.84 & 12.69 & 0 \\
\hline $6 / 27 / 2017$ & Summer & 1:00 AM & 14 & 3.21 & 5.85 & 13.94 & 0 \\
\hline $6 / 27 / 2017$ & Summer & 2:00 AM & 15 & 3.25 & 5.88 & 14.23 & 0 \\
\hline $6 / 27 / 2017$ & Summer & 3:00 AM & 16 & 3.24 & 5.86 & 14.90 & 0 \\
\hline $6 / 27 / 2017$ & Summer & 4:00 AM & 17 & 3.24 & 5.87 & 15.66 & 0 \\
\hline $6 / 27 / 2017$ & Summer & 5:00 AM & 18 & 3.24 & 5.88 & 16.52 & 2583 \\
\hline $6 / 27 / 2017$ & Summer & 6:00 AM & 19 & 3.25 & 5.88 & 17.86 & 9300 \\
\hline $6 / 27 / 2017$ & Summer & 7:00 AM & 20 & 3.24 & 5.87 & 19.38 & 15156 \\
\hline $6 / 27 / 2017$ & Summer & $8: 00$ AM & 21 & 3.26 & 5.88 & 22.62 & 22045 \\
\hline $6 / 27 / 2017$ & Summer & 9:00 AM & 22 & 3.30 & 5.90 & 23.48 & 24800 \\
\hline $6 / 27 / 2017$ & Summer & $10: 00 \mathrm{AM}$ & 23 & 3.28 & 5.91 & 25.71 & 41334 \\
\hline $6 / 27 / 2017$ & Summer & 11:00 AM & 24 & 3.33 & 5.91 & 31.98 & 57867 \\
\hline $6 / 27 / 2017$ & Summer & 12:00 PM & 1 & 2.55 & 5.68 & 31.47 & 37200 \\
\hline $6 / 27 / 2017$ & Summer & 1:00 PM & 2 & 2.72 & 5.66 & 31.98 & 38578 \\
\hline $6 / 27 / 2017$ & Summer & 2:00 PM & 3 & 2.89 & 5.70 & 33.22 & 37200 \\
\hline $6 / 27 / 2017$ & Summer & 3:00 PM & 4 & 2.99 & 5.79 & 35.22 & 34445 \\
\hline $6 / 27 / 2017$ & Summer & 4:00 PM & 5 & 3.07 & 5.74 & 34.16 & 30311 \\
\hline $6 / 27 / 2017$ & Summer & 5:00 PM & 6 & 3.09 & 5.76 & 30.26 & 21356 \\
\hline $6 / 27 / 2017$ & Summer & 6:00 PM & 7 & 3.12 & 5.78 & 24.26 & 8611 \\
\hline $6 / 27 / 2017$ & Summer & 7:00 PM & 8 & 3.14 & 5.79 & 20.81 & 5167 \\
\hline $6 / 27 / 2017$ & Summer & 8:00 PM & 9 & 3.16 & 5.81 & 11.24 & 0 \\
\hline $6 / 27 / 2017$ & Summer & 9:00 PM & 10 & 3.17 & 5.81 & 10.55 & 0 \\
\hline $6 / 27 / 2017$ & Summer & 10:00 PM & 11 & 3.21 & 5.85 & 10.16 & 0 \\
\hline $6 / 27 / 2017$ & Summer & 11:00 PM & 12 & 3.17 & 5.83 & 9.97 & 0 \\
\hline $7 / 5 / 2017$ & Summer & $12: 00$ AM & 12 & 4.67 & 6.12 & 20.71 & 0 \\
\hline $7 / 5 / 2017$ & Summer & 1:00 AM & 13 & 4.05 & 5.35 & 19.85 & 0 \\
\hline $7 / 5 / 2017$ & Summer & 2:00 AM & 14 & 4.71 & 6.12 & 17.38 & 0 \\
\hline $7 / 5 / 2017$ & Summer & $3: 00$ AM & 15 & 4.71 & 6.13 & 16.71 & 0 \\
\hline $7 / 5 / 2017$ & Summer & 4:00 AM & 16 & 4.72 & 6.13 & 18.33 & 0 \\
\hline $7 / 5 / 2017$ & Summer & 5:00 AM & 17 & 4.73 & 6.13 & 18.05 & 3617 \\
\hline $7 / 5 / 2017$ & Summer & 6:00 AM & 18 & 4.75 & 6.15 & 20.23 & 8611 \\
\hline $7 / 5 / 2017$ & Summer & 7:00 AM & 19 & 4.75 & 6.11 & 32.70 & 34445 \\
\hline $7 / 5 / 2017$ & Summer & $8: 00$ AM & 20 & 4.75 & 6.13 & 34.16 & 49600 \\
\hline \multirow[t]{2}{*}{$7 / 5 / 2017$} & Summer & 9:00 AM & 21 & 4.76 & 6.14 & 34.37 & 74401 \\
\hline & & & & & & & able Continues) \\
\hline
\end{tabular}




\begin{tabular}{|c|c|c|c|c|c|c|c|}
\hline Date & Season & Time & $\begin{array}{l}\text { Order } \\
\text { in } \\
\text { Series }\end{array}$ & $\begin{array}{l}\mathrm{NO}_{3}{ }^{-} \mathrm{N} \\
(\mathrm{mg} / \mathrm{L})\end{array}$ & $\begin{array}{c}\mathrm{Cl}^{-} \\
(\mathrm{mg} / \mathrm{L})\end{array}$ & $\begin{array}{c}\text { Air } \\
\text { Temperature } \\
\text { (Hourly) }\left({ }^{\circ} \mathrm{C}\right) \\
\end{array}$ & $\begin{array}{l}\text { Solar Intensity } \\
\text { (Hourly) (lux) }\end{array}$ \\
\hline $7 / 5 / 2017$ & Summer & 10:00 AM & 22 & 4.76 & 6.12 & 37.71 & 57867 \\
\hline $7 / 5 / 2017$ & Summer & 11:00 AM & 23 & 4.79 & 6.11 & 38.60 & 77156 \\
\hline $7 / 5 / 2017$ & Summer & 12:00 PM & 24 & 4.80 & 6.12 & 40.99 & 49600 \\
\hline $7 / 5 / 2017$ & Summer & 1:00 PM & 1 & 4.11 & 6.08 & 30.86 & 31689 \\
\hline $7 / 5 / 2017$ & Summer & 2:00 PM & 2 & 4.22 & 6.01 & 32.70 & 41334 \\
\hline $7 / 5 / 2017$ & Summer & 3:00 PM & 3 & 4.33 & 6.01 & 33.33 & 37200 \\
\hline $7 / 5 / 2017$ & Summer & 4:00 PM & 4 & 4.42 & 6.02 & 37.49 & 34445 \\
\hline $7 / 5 / 2017$ & Summer & 5:00 PM & 5 & 4.50 & 6.05 & 30.36 & 15845 \\
\hline $7 / 5 / 2017$ & Summer & 6:00 PM & 6 & 4.55 & 6.06 & 26.88 & 4306 \\
\hline $7 / 5 / 2017$ & Summer & 7:00 PM & 7 & 4.58 & 6.06 & 24.55 & 1109 \\
\hline $7 / 5 / 2017$ & Summer & 8:00 PM & 8 & 4.61 & 6.07 & 22.14 & 0 \\
\hline $7 / 5 / 2017$ & Summer & 9:00 PM & 9 & 4.62 & 6.09 & 22.33 & 0 \\
\hline $7 / 5 / 2017$ & Summer & 10:00 PM & 10 & 4.63 & 6.08 & 21.57 & 0 \\
\hline $7 / 5 / 2017$ & Summer & 11:00 PM & 11 & 4.66 & 6.11 & 20.90 & 0 \\
\hline $7 / 12 / 2017$ & Summer & $12: 00 \mathrm{AM}$ & 10 & 5.48 & 6.27 & 22.72 & 0 \\
\hline $7 / 12 / 2017$ & Summer & 1:00 AM & 11 & 5.50 & 6.29 & 22.53 & 0 \\
\hline $7 / 12 / 2017$ & Summer & 2:00 AM & 12 & 5.51 & 6.28 & 22.24 & 0 \\
\hline $7 / 12 / 2017$ & Summer & 3:00 AM & 13 & 5.55 & 6.29 & 21.95 & 0 \\
\hline $7 / 12 / 2017$ & Summer & 4:00 AM & 14 & 5.59 & 6.30 & 22.53 & 0 \\
\hline $7 / 12 / 2017$ & Summer & 5:00 AM & 15 & 5.55 & 6.30 & 23.20 & 1378 \\
\hline $7 / 12 / 2017$ & Summer & 6:00 AM & 16 & 5.54 & 6.29 & 22.53 & 1184 \\
\hline $7 / 12 / 2017$ & Summer & 7:00 AM & 17 & 5.55 & 6.30 & 23.00 & 7233 \\
\hline $7 / 12 / 2017$ & Summer & $8: 00$ AM & 18 & 5.57 & 6.30 & 27.76 & 33067 \\
\hline $7 / 12 / 2017$ & Summer & 9:00 AM & 19 & 5.55 & 6.29 & 29.75 & 41334 \\
\hline $7 / 12 / 2017$ & Summer & 10:00 AM & 20 & 5.56 & 6.31 & 34.90 & 74401 \\
\hline $7 / 12 / 2017$ & Summer & 11:00 AM & 21 & 5.55 & 6.32 & 38.27 & 68889 \\
\hline $7 / 12 / 2017$ & Summer & $12: 00$ PM & 22 & 5.58 & 6.31 & 37.06 & 55112 \\
\hline $7 / 12 / 2017$ & Summer & 1:00 PM & 23 & 5.61 & 6.32 & 38.05 & 63378 \\
\hline $7 / 12 / 2017$ & Summer & 2:00 PM & 24 & 5.63 & 6.31 & 41.23 & 52356 \\
\hline $7 / 12 / 2017$ & Summer & 3:00 PM & 1 & 4.99 & 6.33 & 32.39 & 24800 \\
\hline $7 / 12 / 2017$ & Summer & 4:00 PM & 2 & 5.11 & 6.25 & 39.62 & 42711 \\
\hline $7 / 12 / 2017$ & Summer & 5:00 PM & 3 & 5.22 & 6.24 & 39.96 & 24800 \\
\hline $7 / 12 / 2017$ & Summer & 6:00 PM & 4 & 5.31 & 6.24 & 31.06 & 7233 \\
\hline $7 / 12 / 2017$ & Summer & 7:00 PM & 5 & 5.37 & 6.23 & 28.56 & 517 \\
\hline $7 / 12 / 2017$ & Summer & 8:00 PM & 6 & 5.42 & 6.26 & 27.86 & 0 \\
\hline
\end{tabular}

(Table Continues) 


\begin{tabular}{|c|c|c|c|c|c|c|c|}
\hline Date & Season & Time & $\begin{array}{l}\text { Order } \\
\text { in } \\
\text { Series } \\
\end{array}$ & $\begin{array}{l}\mathrm{NO}_{3}{ }^{-}-\mathrm{N} \\
(\mathrm{mg} / \mathrm{L})\end{array}$ & $\begin{array}{c}\mathrm{Cl}^{-} \\
(\mathrm{mg} / \mathrm{L})\end{array}$ & $\begin{array}{c}\text { Air } \\
\text { Temperature } \\
\text { (Hourly) }\left({ }^{\circ} \mathrm{C}\right)\end{array}$ & $\begin{array}{l}\text { Solar Intensity } \\
\text { (Hourly) (lux) }\end{array}$ \\
\hline $7 / 12 / 2017$ & Summer & 9:00 PM & 7 & 5.45 & 6.24 & 28.16 & 0 \\
\hline $7 / 12 / 2017$ & Summer & 10:00 PM & 8 & 5.47 & 6.27 & 28.26 & 0 \\
\hline $7 / 12 / 2017$ & Summer & 11:00 PM & 9 & 5.47 & 6.25 & 24.84 & 0 \\
\hline $7 / 18 / 2017$ & Summer & $12: 00 \mathrm{AM}$ & 12 & 5.83 & 6.27 & 20.42 & 0 \\
\hline $7 / 18 / 2017$ & Summer & 1:00 AM & 13 & 5.82 & 6.28 & 20.81 & 0 \\
\hline $7 / 18 / 2017$ & Summer & 2:00 AM & 14 & 5.84 & 6.28 & 21.57 & 0 \\
\hline $7 / 18 / 2017$ & Summer & 3:00 AM & 15 & 5.83 & 6.27 & 21.76 & 0 \\
\hline $7 / 18 / 2017$ & Summer & 4:00 AM & 16 & 5.85 & 6.30 & 21.86 & 0 \\
\hline $7 / 18 / 2017$ & Summer & 5:00 AM & 17 & 5.85 & 6.30 & 20.23 & 527 \\
\hline $7 / 18 / 2017$ & Summer & 6:00 AM & 18 & 5.86 & 6.30 & 24.16 & 5511 \\
\hline $7 / 18 / 2017$ & Summer & 7:00 AM & 19 & 5.86 & 6.29 & 33.95 & 31689 \\
\hline $7 / 18 / 2017$ & Summer & $8: 00$ AM & 20 & 5.86 & 6.28 & 35.86 & 44089 \\
\hline $7 / 18 / 2017$ & Summer & 9:00 AM & 21 & 5.86 & 6.29 & 37.49 & 63378 \\
\hline $7 / 18 / 2017$ & Summer & 10:00 AM & 22 & 5.87 & 6.29 & 39.96 & 71645 \\
\hline $7 / 18 / 2017$ & Summer & 11:00 AM & 23 & 5.88 & 6.30 & 42.28 & 79912 \\
\hline $7 / 18 / 2017$ & Summer & $12: 00$ PM & 24 & 5.89 & 6.29 & 44.09 & 60623 \\
\hline $7 / 18 / 2017$ & Summer & 1:00 PM & 1 & 5.60 & 6.40 & 41.46 & 39956 \\
\hline $7 / 18 / 2017$ & Summer & 2:00 PM & 2 & 5.63 & 6.25 & 41.93 & 37200 \\
\hline $7 / 18 / 2017$ & Summer & 3:00 PM & 3 & 5.68 & 6.23 & 43.60 & 38578 \\
\hline $7 / 18 / 2017$ & Summer & 4:00 PM & 4 & 5.70 & 6.24 & 38.38 & 27556 \\
\hline $7 / 18 / 2017$ & Summer & 5:00 PM & 5 & 5.73 & 6.23 & 36.19 & 13778 \\
\hline $7 / 18 / 2017$ & Summer & 6:00 PM & 6 & 5.74 & 6.24 & 30.96 & 5339 \\
\hline $7 / 18 / 2017$ & Summer & 7:00 PM & 7 & 5.77 & 6.25 & 23.97 & 614 \\
\hline $7 / 18 / 2017$ & Summer & 8:00 PM & 8 & 5.79 & 6.26 & 20.42 & 0 \\
\hline $7 / 18 / 2017$ & Summer & 9:00 PM & 9 & 5.80 & 6.27 & 20.04 & 0 \\
\hline $7 / 18 / 2017$ & Summer & 10:00 PM & 10 & 5.81 & 6.28 & 23.58 & 0 \\
\hline $7 / 18 / 2017$ & Summer & 11:00 PM & 11 & 5.82 & 6.27 & 21.57 & 0 \\
\hline $7 / 24 / 2017$ & Summer & $12: 00 \mathrm{AM}$ & 16 & 6.20 & 6.33 & 15.38 & 0 \\
\hline $7 / 24 / 2017$ & Summer & 1:00 AM & 17 & 6.21 & 6.34 & 14.80 & 0 \\
\hline $7 / 24 / 2017$ & Summer & 2:00 AM & 18 & 6.22 & 6.35 & 12.59 & 0 \\
\hline $7 / 24 / 2017$ & Summer & 3:00 AM & 19 & 6.24 & 6.36 & 12.88 & 0 \\
\hline $7 / 24 / 2017$ & Summer & 4:00 AM & 20 & 6.24 & 6.38 & 14.33 & 0 \\
\hline $7 / 24 / 2017$ & Summer & 5:00 AM & 21 & 6.26 & 6.35 & 14.23 & 1464 \\
\hline $7 / 24 / 2017$ & Summer & $6: 00 \mathrm{AM}$ & 22 & 6.27 & 6.35 & 19.57 & 22045 \\
\hline \multirow[t]{2}{*}{$7 / 24 / 2017$} & Summer & 7:00 AM & 23 & 6.29 & 6.37 & 24.84 & 34445 \\
\hline & & & & & & & able Continues) \\
\hline
\end{tabular}




\begin{tabular}{|c|c|c|c|c|c|c|c|}
\hline Date & Season & Time & $\begin{array}{l}\text { Order } \\
\text { in } \\
\text { Series }\end{array}$ & $\begin{array}{l}\mathrm{NO}_{3}^{-}-\mathrm{N} \\
(\mathrm{mg} / \mathrm{L})\end{array}$ & $\begin{array}{c}\mathrm{Cl}^{-} \\
(\mathrm{mg} / \mathrm{L})\end{array}$ & $\begin{array}{c}\text { Air } \\
\text { Temperature } \\
\text { (Hourly) }\left({ }^{\circ} \mathrm{C}\right)\end{array}$ & $\begin{array}{l}\text { Solar Intensity } \\
\text { (Hourly) (lux) }\end{array}$ \\
\hline $7 / 24 / 2017$ & Summer & 8:00 AM & 24 & 6.30 & 6.37 & 27.57 & 49600 \\
\hline $7 / 24 / 2017$ & Summer & 9:00 AM & 1 & 5.75 & 6.33 & 24.84 & 24800 \\
\hline $7 / 24 / 2017$ & Summer & 10:00 AM & 2 & 5.82 & 6.23 & 27.57 & 42711 \\
\hline $7 / 24 / 2017$ & Summer & 11:00 AM & 3 & 5.90 & 6.24 & 27.37 & 37200 \\
\hline $7 / 24 / 2017$ & Summer & $12: 00$ PM & 4 & 5.95 & 6.26 & 29.25 & 33067 \\
\hline $7 / 24 / 2017$ & Summer & 1:00 PM & 5 & 6.01 & 6.26 & 35.01 & 60623 \\
\hline $7 / 24 / 2017$ & Summer & 2:00 PM & 6 & 6.02 & 6.26 & 38.49 & 44089 \\
\hline $7 / 24 / 2017$ & Summer & 3:00 PM & 7 & 6.06 & 6.28 & 30.05 & 27556 \\
\hline $7 / 24 / 2017$ & Summer & 4:00 PM & 8 & 6.06 & 6.29 & 33.54 & 38578 \\
\hline $7 / 24 / 2017$ & Summer & 5:00 PM & 9 & 6.08 & 6.30 & 30.86 & 20667 \\
\hline $7 / 24 / 2017$ & Summer & 6:00 PM & 10 & 6.13 & 6.30 & 25.32 & 6200 \\
\hline $7 / 24 / 2017$ & Summer & 7:00 PM & 11 & 6.11 & 6.30 & 22.43 & 2670 \\
\hline $7 / 24 / 2017$ & Summer & 8:00 PM & 12 & 6.14 & 6.31 & 17.67 & 0 \\
\hline $7 / 24 / 2017$ & Summer & 9:00 PM & 13 & 6.14 & 6.29 & 17.09 & 0 \\
\hline $7 / 24 / 2017$ & Summer & 10:00 PM & 14 & 6.17 & 6.32 & 16.62 & 0 \\
\hline $7 / 24 / 2017$ & Summer & 11:00 PM & 15 & 6.24 & 6.33 & 15.38 & 0 \\
\hline $8 / 2 / 2017$ & Summer & $12: 00 \mathrm{AM}$ & 13 & 5.92 & 6.20 & 15.00 & 0 \\
\hline $8 / 2 / 2017$ & Summer & 1:00 AM & 14 & 5.94 & 6.20 & 15.19 & 0 \\
\hline $8 / 2 / 2017$ & Summer & 2:00 AM & 15 & 5.93 & 6.20 & 14.80 & 0 \\
\hline $8 / 2 / 2017$ & Summer & 3:00 AM & 16 & 5.94 & 6.21 & 15.19 & 0 \\
\hline $8 / 2 / 2017$ & Summer & 4:00 AM & 17 & 5.99 & 6.23 & 15.57 & 0 \\
\hline $8 / 2 / 2017$ & Summer & 5:00 AM & 18 & 5.97 & 6.23 & 15.38 & 409 \\
\hline $8 / 2 / 2017$ & Summer & 6:00 AM & 19 & 5.96 & 6.24 & 19.47 & 12400 \\
\hline $8 / 2 / 2017$ & Summer & 7:00 AM & 20 & 5.97 & 6.22 & 26.98 & 16533 \\
\hline $8 / 2 / 2017$ & Summer & $8: 00$ AM & 21 & 5.97 & 6.22 & 34.27 & 49600 \\
\hline $8 / 2 / 2017$ & Summer & 9:00 AM & 22 & 5.97 & 6.26 & 36.73 & 66134 \\
\hline $8 / 2 / 2017$ & Summer & 10:00 AM & 23 & 5.97 & 6.22 & 37.38 & 79912 \\
\hline $8 / 2 / 2017$ & Summer & 11:00 AM & 24 & 6.00 & 6.23 & 34.48 & 52356 \\
\hline $8 / 2 / 2017$ & Summer & 12:00 PM & 1 & 5.10 & 6.50 & 41.93 & 85423 \\
\hline $8 / 2 / 2017$ & Summer & 1:00 PM & 2 & 5.48 & 6.19 & 41.34 & 60623 \\
\hline $8 / 2 / 2017$ & Summer & 2:00 PM & 3 & 5.57 & 6.11 & 36.51 & 37200 \\
\hline $8 / 2 / 2017$ & Summer & 3:00 PM & 4 & 5.60 & 6.11 & 40.42 & 37200 \\
\hline $8 / 2 / 2017$ & Summer & 4:00 PM & 5 & 5.63 & 6.11 & 39.50 & 27556 \\
\hline $8 / 2 / 2017$ & Summer & 5:00 PM & 6 & 5.74 & 6.18 & 36.08 & 17911 \\
\hline $8 / 2 / 2017$ & Summer & 6:00 PM & 7 & 5.78 & 6.15 & 27.76 & 4478 \\
\hline
\end{tabular}




\begin{tabular}{|c|c|c|c|c|c|c|c|}
\hline Date & Season & Time & $\begin{array}{l}\text { Order } \\
\text { in } \\
\text { Series }\end{array}$ & $\begin{array}{l}\mathrm{NO}_{3}{ }^{-}-\mathrm{N} \\
(\mathrm{mg} / \mathrm{L})\end{array}$ & $\begin{array}{c}\mathrm{Cl}^{-} \\
(\mathrm{mg} / \mathrm{L})\end{array}$ & $\begin{array}{c}\text { Air } \\
\text { Temperature } \\
\text { (Hourly) }\left({ }^{\circ} \mathrm{C}\right)\end{array}$ & $\begin{array}{c}\text { Solar Intensity } \\
\text { (Hourly) (lux) }\end{array}$ \\
\hline $8 / 2 / 2017$ & Summer & 7:00 PM & 8 & 5.78 & 6.15 & 21.28 & 850 \\
\hline $8 / 2 / 2017$ & Summer & 8:00 PM & 9 & 5.85 & 6.18 & 17.95 & 0 \\
\hline $8 / 2 / 2017$ & Summer & 9:00 PM & 10 & 5.88 & 6.18 & 17.00 & 0 \\
\hline $8 / 2 / 2017$ & Summer & 10:00 PM & 11 & 5.90 & 6.19 & 16.05 & 0 \\
\hline $8 / 2 / 2017$ & Summer & 11:00 PM & 12 & 5.98 & 6.21 & 15.38 & 0 \\
\hline $8 / 8 / 2017$ & Summer & $12: 00 \mathrm{AM}$ & 14 & 5.02 & 6.02 & 9.08 & 0 \\
\hline $8 / 8 / 2017$ & Summer & 1:00 AM & 15 & 5.02 & 6.02 & 8.58 & 0 \\
\hline $8 / 8 / 2017$ & Summer & 2:00 AM & 16 & 5.02 & 6.03 & 8.38 & 0 \\
\hline $8 / 8 / 2017$ & Summer & 3:00 AM & 17 & 4.97 & 6.04 & 7.98 & 0 \\
\hline $8 / 8 / 2017$ & Summer & 4:00 AM & 18 & 5.01 & 6.04 & 7.68 & 0 \\
\hline $8 / 8 / 2017$ & Summer & 5:00 AM & 19 & 5.02 & 6.09 & 7.18 & 323 \\
\hline $8 / 8 / 2017$ & Summer & $6: 00 \mathrm{AM}$ & 20 & 4.92 & 6.09 & 16.52 & 14467 \\
\hline $8 / 8 / 2017$ & Summer & 7:00 AM & 21 & 5.01 & 6.12 & 30.76 & 34445 \\
\hline $8 / 8 / 2017$ & Summer & $8: 00$ AM & 22 & 4.90 & 6.10 & 32.81 & 49600 \\
\hline $8 / 8 / 2017$ & Summer & 9:00 AM & 23 & 4.92 & 6.08 & 34.80 & 68889 \\
\hline $8 / 8 / 2017$ & Summer & $10: 00 \mathrm{AM}$ & 24 & 4.97 & 6.09 & 33.54 & 28934 \\
\hline $8 / 8 / 2017$ & Summer & $11: 00 \mathrm{AM}$ & 1 & 5.43 & 6.26 & 37.06 & 82667 \\
\hline $8 / 8 / 2017$ & Summer & 12:00 PM & 2 & 5.37 & 6.13 & 35.65 & 68889 \\
\hline $8 / 8 / 2017$ & Summer & 1:00 PM & 3 & 5.31 & 6.11 & 35.97 & 37200 \\
\hline $8 / 8 / 2017$ & Summer & 2:00 PM & 4 & 5.23 & 6.11 & 36.30 & 34445 \\
\hline $8 / 8 / 2017$ & Summer & 3:00 PM & 5 & 5.21 & 6.09 & 36.84 & 30311 \\
\hline $8 / 8 / 2017$ & Summer & 4:00 PM & 6 & 5.12 & 6.07 & 35.65 & 26178 \\
\hline $8 / 8 / 2017$ & Summer & 5:00 PM & 7 & 5.08 & 6.06 & 36.95 & 20667 \\
\hline $8 / 8 / 2017$ & Summer & 6:00 PM & 8 & 5.04 & 6.06 & 25.42 & 5167 \\
\hline $8 / 8 / 2017$ & Summer & 7:00 PM & 9 & 5.13 & 6.01 & 16.14 & 398 \\
\hline $8 / 8 / 2017$ & Summer & 8:00 PM & 10 & 5.01 & 6.02 & 11.92 & 0 \\
\hline $8 / 8 / 2017$ & Summer & 9:00 PM & 11 & 5.11 & 6.03 & 10.65 & 0 \\
\hline $8 / 8 / 2017$ & Summer & 10:00 PM & 12 & 4.96 & 6.01 & 10.06 & 0 \\
\hline $8 / 8 / 2017$ & Summer & 11:00 PM & 13 & 5.03 & 6.01 & 9.57 & 0 \\
\hline
\end{tabular}

Note. Includes: date, season, hour, order-in-series, $\mathrm{NO}_{3}{ }^{-} \mathrm{N}, \mathrm{Cl}^{-}$, air temperature, and solar intensity. 